\title{
KURAS JE
}

NR.29

Marxistisk tidsskrift

KURASJE

Krystalgade 16/14 1172 Kbh. K.

\section{Tema:}

IMPERIALISME OG VERDENSMARKED REFORMISMETEORI 
Abonnement på kurasje nr. 29-32 koster følgende:

Biblioteker

Støtteabonnementer

Studerende o.lign.

Folk med fast arbejde
$160 \mathrm{kr}$.

$160 \mathrm{kr}$.

$120 \mathrm{kr}$.

$140 \mathrm{kr}$.

Kurasjes gironummer: 7166044

Kurasje

Krystalgade 16

1172 København K

Tegn abonnement, skaf flere abonnenter, brug Kurasje.

Kurasje har fast ekspeditionstid:

Mandag 14-17, onsdag fra 12-16 og fredag fra 12-16. Telf.: 01-147151

Sats: G.M.T.

Tryk: Special-Trykkeriet Viborg a-s. 


\section{TIDSSKRIFTET KURASJE Nr. 29 \\ Oktober 1981}

\section{INDHOLD}

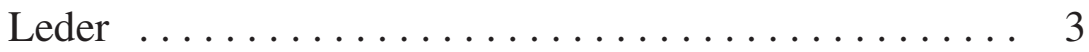

Introducerende note om verdensmarkedstemaet $\ldots \ldots \ldots 5$

Anwar Shaikh, Udenrigshandel og værdilov ....... 9

Tilla Siegel, Værdilov og verdensmarked ......... 39

Introducerende note om reformismetemaet $\ldots \ldots \ldots 63$

Bernhard Blanke, Socialdemokrati og samfundskrise . . 67

Finn Dam Rasmussen, Tiden råber på..? . . . . . . . . . 93

Redaktionen: Bjarne Andersson, Allan Andreassen, Flemming Bahner, Nils Bredsdorff, Jens Brinch, Peter Bundesen, Carl-Ivar Carlin, Bo Elling, Leif Hansen, Finn Hansson, Erling Havn, Mogens Holm, Hans Hornbech, Søren Kerndrup, Tyge Kjær, Arne Kurdahl, Peder Lærke Nielsen, Lars Qvortrup, Finn Dam Rasmussen og Peter Søndergaard.

Tidsskriftet behandler en lang række emner med det formål at bidrage til etableringen af en konkret formidlet kritik af det kapitalistiske system og det borgerlige samfund, samt til diskussionen af overgangsformer til det kommunistiske samfund. Vi opfordrer interesserede til at indsende manuskripter især vedrørende følgende emner: analyse af den kapitalistiske akkumulations- og reproduktionsproces og dens kriser; analyser af arbejderbevægelsens historie, fagforeningsanalyser, klasseanalyser, kritik af reformismen; analyse af staten i det kapitalistiske samfund; analyse af verdensmarkedets udvikling og af tendensen til dannelsen af en verdensmarkedskapital; analyse af overgangsformer og overgangssamfund.

Redaktionens adresse:

Kurasje, Krystalgade 16/14, DK-1172 København K 


\section{Finn Dam Rasmussen:}

Arbejderens situation, de sociale problemer og revolutionen

»Skal man gå ud fra, at arbejderne nu har fået det så godt i de vestlige kapitalistiske lande, at de ikke mere vil lave revolution - eller bliver behovet for arbejderklassens sociale emancipation stadigt st $\varnothing$ rre med kapitalismens historiske udvikling? For at kunne tage dette problem om revolutionens mulighed og nødvendighed op er det først og fremmest nødvendigt at finde ud af, hvad det egentlig er, arbejderklassen skal befri sig fra,... sin eksistens som kapitalens lønarbejder. Denne specifikke historiske form for menneskenes samfundsmæssige eksistens betegnes i det følgende som »arbejderens situation« og er emnet for denne bog.« (fra indledningen)

176 sider; kr. 65,--

\section{Socialpolitik og kapitalisme}

En antologi om de sociale problemer, deres årsager og formål under kapitalismen

\section{samt om at analysere disse problemer marxitisk}

I antologien:

- skriver Böhle og Sauer om intensivering af arbejdet og statslig socialpolitik,

- Kritiseres Böhle og Sauer af Claus Offe, der får svar på tiltale,

- Analyserer Finn Dam Rasmussen og Peter Bundesen de sociale problemers sammenhæng med kapitalismen,

- Kritiserer Torben Pilegaard Jensen den borgerlige social- og arbejdsmarkedspolitiske teori, og endelig

- Diskuterer Svend Solvig og Peter Abrahamsen marxistiske analyser af socialpolitik i Danmark.

156 sider kr. 60,-

Bøgerne kan ligesom Kurasjes andre bøger købes i bogcafeer og boglader, eller bestilles direkte hos Kurasje ved forudbetaling på giro: 7166044 . 


\section{Leder}

I dette nummer tager vi to temaer op: Imperialismen og reformismen. Emnernes aktualitet behøver vel ingen særlig argumentation i en tid med øget rivalisering mellem de kapitalistiske lande og en tilsyneladende usvækket opbakning bag en reformistisk arbejderbevægelse trods 8 års krise og arbejdsløshed.

Vores valg af netop de hér fremlagte analysebidrag kan dog fortjene en kort kommentar. Den ene af de to »imperialismeartikler« (Shaikh) giver den teorihistoriske baggrund for forståelsen af udviklingen i udenrigshandels- og verdensmarkedsteorierne. Formålet er at give en baggrund for vurderingen af de mangeartede analyser, som reorganiseringen af den kapitalistiske verdensøkonomi efter krisens gennemslag har fået til at skyde op. Den anden (Siegel) er et fors $\emptyset$ g på en videreudvikling af nogle centrale marxistiske verdensmarkedsanalyser (Busch og Neusüss) gennem et kritisk opgør med dem. For den danske debat har artiklen derudover den fordel, at begge de kritiserede forfatteres arbejder foreligger på dansk.

Artiklen om reformismen er på een gang et teorihistorisk opgør med en række traditionelle - borgerlige og marxistiske - reformismeanalyser, og et fors $\varnothing g$ på en begrebsligg $\varnothing$ relse af centrale elementer i forholdet mellem politik og økonomi. På hvilken måde strukturerer forholdet mellem lønarbejde og kapital arbejderbevægelsens strategi og handlemuligheder?

Disse tre artikler er oversatte arbejder af den simple grund, at der ikke findes mere tænksomme og tankeprovokerende arbejder på dansk om disse emner - for nu at sige det pænt.

Nummeret afsluttes med en længere kritisk kommentar til nogle centrale venstrefløjsudgivelser - vores eget Kurasje 26 om realanalysen og den materialistiske historieopfattelse, HUG!'s temanummer om moral og Göran Therborns nye bog »The power of ideology and the ideology of power .

» Iøvrigt mener vi«, at du skal forny dit abonnement eller hvis det er sket, skaffe en ny abonnent. Men du kan jo også vente til du har læst dette nummer. Overbeviser det dig ikke, så drop sagen.

Statens samfundsvidenskabelige Forskningsråd har ydet en produktionsstøtte til dette nummer. 


\title{
STATEN I DET KAPITALISTISKE SAMFUND - EN INTRODUKTION.
}

\author{
Genoptryk af artikler fra Kurasje. \\ 72 sider, 25,- kr.
}

I den diskussion af staten i det kapitalistiske samfund, som startede i Danmark i begyndelsen af 70'erne, indtog Elmar Altvaters artikel $\gg \mathrm{Om}$ nogle problemer ved statsinterventionismen « en central plads. I diskussionens forløb overså mange, både »tilhængere « og »modstandere«, hvad artiklens centrale problemstilling var. Når man dengang lagde hovedvægten på Altvarters forsøg på at bestemme centrale statsfunktioner, overså man, at artiklen primært er en kritik af den keynesianske blandings $\varnothing$ konomi - af denne $\varnothing$ konomiske poltisks grænser og dens midlers binding til cirkulationssfæren. Ligeledes påviser artiklen hvorledes de borgerlige $\varnothing$ konomer og »politikmagere« er fikseret i disse sammenhænge og ikke kan begribe de egentlige akkumulationsproblemer for kapitalen.

Og disse kritikpunkter kan næppe siges at være blevet gjort overflødige. De sidste 5 års krise og desperate statslige løsningsfors $\emptyset \mathrm{g}$ har tværtimod gjort det endnu mere nødvendigt for socialister at fastholde en konsekvent kritik af de statslige kriseløsninger - lige meget hvorfra de så kommer!

I den forstand er artiklerne i denne bog lige så aktuelle som da de første gang udkom og er stadig de bedste introduktioner til statsdiskussionen. 


\title{
Introducerende note til verdensmarkedstemaet.
}

\author{
Arne Wangel.
}

Publiceringen på dansk af de efterfølgende to nye bidrag til den marx'ske teori om udenrigshandel og verdensmarked giver anledning til at opridse diskussionens forløb på dansk grund siden oversættelsen i 1976 af to hovedværker inden for området ${ }^{1}$. Da der fornylig er fremkommet en rimelig dækkende annoteret bibliografi over dansk imperialisme-litteratur ${ }^{2}$, skal jeg her nøjes med at nævne enkelte karakteristiske indlæg.

To særegne forhold kendetegner arbejdet inden for emneområderne udenrigshandel og verdensmarked. For det første et relativt generelt teorigrundlag; Marx fik aldrig skrevet sine planlagte bøger om de to emner. Det teoretiske arbejde er således henvist til at tage udgangspunkt i 'Kapitalens' få og spredte bemærkninger. For det andet rummer emnerne et empirisk felt af usædvanligt omfang. Den mangelfulde teori og stoffets bredde bliver et alvorligt problem stillet over for den politiske nødvendighed af umiddelbare analyser af den internationale $\varnothing$ konomiske krise, tendenserne mod en ny international arbejdsdeling, imperialismens strategi mm.

I 1976 tog diskussionen udgangspunkt i to teoretiske spørgsmål i relation til kapitalens verdensmarkedsbevægelse, dels vdr. en nærmere bestemmelse af nationalstaten som skranke for denne, dels vdr. værdidannelsens niveau - tendensielt internationalt under kapitalens internationalisering eller fortsat nationelt. Vdr. det første spørgsmål blev der argumenteret for, at den historiske udvikling i varetagelsen af kapitalforholdet i nationalstatens regi danner en absolut skranke i kapitalens internationaliseringsproces ${ }^{3}$. Debatten om værdidannelsens niveau var først og fremmest inspireret af Wolfgang Schoellers ikke oversatte kritik af Neusüss og Busch ${ }^{4}$. Kritikkens hovedpunkter findes refereret og diskuteret i en bredt anlagt imperialisme-

1. Christel Neusüss: Imperialismen og det kapitalistiske verdensmarked. København 1976. Klaus Busch: Imperialismen og de multinationale selskaber. Århus 1976.

2. Poul Mikael Allarp: Teoretiske bidrag til forståelse af imperialismen og den globale udvikling. Annoteret bibliografi over danske bøger og udvalgte tidsskrifter 1970-79. København 1980.

3. Arne Wangel: Kapitalens bevægelser på verdensmarkedet og nationalstaten. Sociologisk Institut. København 1976. Karakteren af nationalstaten som skranke diskuteres her i forhold til den vesteuropæiske integrationsproces.

4. Wolfgang Schoeller: Weltmarkt und Reproduktion des Kapitals. Frankfurt am Main Köln 1976. 
analyse udarbejdet af et forfatterkollektiv ${ }^{5}$. Spørgsmålet om værdidannelsens niveau overskygges dog af kritikken af teoridannelsens begrænsede forklaringskraft sammenlignet med den omfattende forklaringsramme, som det er forfatterkollektivets ambition at etablere til analyse af grundlag, funktion og konsekvens i kapitalismens globale ekspansion. Kritikken udtrykkes bl.a. således: »Den synkrone verdenshandelsmodel kan ikke reflektere disse historisk satte betingelser for byttet på verdensmarkedet, men kan »kun « teoretisere over fænomener (ulige bytte af værdier/arbejdskvanta), som er afledt af produktionssfærens historisk satte struktur« (p. 138).

»Med u-landsproblemet er vi m.a.o. nået til grænserne for den logisk afledte models forklaringskraft «, konkluderer forfatterkollektivet.

Men selvom Neusüss og Busch lægger hovedvægten på forklaringen af fænomener i den internationale cirkalationssfære, hvilket må forstås på baggrund af deres vigtige opgør med Emmanuels forfejlede udenrigshandelsteori om et ulige bytte af værdi mellem i- og u-lande, fik teoriens perspektiv en afgørende betydning netop for ulandsproblemet. Reaktualiseringen af de klassiske imperialismeteoretikeres problemstilling: at forklare imperialismen ud fra kapitalens tendens til ekspansion gav grundlag for at formulere, at »hovedkritikken af afhængighedsteorierne er, at de ikke har analyseret dynamikken i imperialismen ud fra lovmæssighederne i kapitalakkumulationen i centeret $\ll^{6}$.

Afhængighedsteoriernes begreb om den »blokerede udvikling « i de perifere lande blev også brudt af den empiriske konstatering af fremvoksende sammenhængende kapitalismestrukturer i en række af disse lande ${ }^{7}$. Imperialismeteoretisk blev der hentet inspiration hos den franske $\varnothing$ konom Christian Paloix, hvis model netop søger at indplacere de perifere lande i en international reproduktionsdynamik ${ }^{8}$.

Men for den videre analyse af imperialismens resultat - underudviklingen - trådte væsentlige problemer tydeligere frem: »En imperialismeteori,

5. Forfatterkollektiv: Imperialisme. Grundlag, Funktion, Konsekvens $i$ Den Jyske Historiker nr. 11. Århus 1977.

6. Thyge Enevoldsen: Status på vej mod en ny imperialismeteori $i$ Kulturgeografiske Hæfter nr. 13, København 1978.

7. Henrik Secher Marcussen: Mod et paradigmeskift i udviklingsforskningen? $i$ Nordisk Forum nr. 24, København 1980.

Se også Henrik Secher Marcussen og Jens Erik Torp: Fra afhængighedsanalyse til teori om kapitalens internationalisering $i$ Økonomi og Politik nr. 3, København 1977.

8. Annette Møller et al.: Ændringer i det internationale reproduktionshierarki - Danmarks placering heri. Institut for geografi, samfundsanalyse og datalogi. Roskilde 1980. Forskningsrapport nr. 8 . 
der tager udgangspunkt i kapitalens almene bevægelser på verdensmarkedet, er således kun i stand til at analysere »periferi« imperialismen udfra hvorledes periferien inddrages af center-interne årsager, og den nødvendige subsumtion (underordning) af de ikkekapitalistiske produktionsmåder kan kun analyseres ud fra dens nødvendighed for kapitalismen « (op.cit. p. 11).

Denne problemstilling gennemarbejdes af Anders Chr. Jensen ${ }^{9}$, som s $\varnothing-$ ger at »bestemme agrarsektorens reproduktionskarakter, hvilket vil sige hvorledes de $\varnothing$ konomiske, politiske og sociale ændringer i agrarsektoren er et resultat af sektorens integration i den afhængige kapitalisme. Den afhængige kapitalisme er uløseligt forbundet med imperialismen, således at den globale kapitalismes reproduktion er en del af den afhængige kapitalismes reproduktion i Brasilien. (p. 11). Thyge Enevoldsen har i en senere artikel søgt teoretisk at præcisere skrankerne i underordningen af ikke-kapitalistisk produktion og ikkekapitalistiske producenter under kapitalen ${ }^{10}$. Her understreger han netop de historisk-konkrete studier som forudsætning for en positiv bestemmelse af skrankerne.

Senest har Georg Sørensen bidraget med en teorihistorisk oversigt ${ }^{11}$ som peger tilbage mod diskussionens udgangspunkt. I bogen udvikler han en kritik af centrale teoridannelser inden for disciplinen 'international politik' i lyset af imperialisme-forskningens resultater og leverer hermed et grundmateriale, der ligesom de følgende to artikler inspirerer til at genoptage en systematisk oparbejdning af den marxistiske teori om udenrigshandel og verdensmarkedskrise.

9. Anders Chr. Jensen: Den brasilianske agrarsektors reproduktion under imperialismens dominans 1955-78. Sociologisk Institut, Arbejdspapir nr. 20. København 1979.

10. Thyge Enevoldsen: Imperialismeteori: Expansion og underordning $i$ Kulturgeografiske Hæfter nr. 17. København 1980.

Artiklen sammendrager pointer fra et større arbejde: A. Bredsdorff et al.: Træk af den internationale sociale arbejdsdeling belyst ved afrikanske eksempler. Geografisk Institut. København 1979. (specielt kapitel 3).

11. Georg Sørensen: International politik og marxisme. Aalborg 1980. 


\title{
GENUDGIVELSE
}

\author{
Oskar Negt
}

\section{SOCIOLOGISK FANTASI OG EKSEMPLARISK INDLERING}

Bogladepris 48,- kr. Abn. pris 39,- kr.

Kurasje, Krystalgade 14/16, 1172 K, giro 7166044 


\title{
Udenrigshandel og værdilov.
}

\author{
Anwar Shaikh
}

Første del*

\section{Indledning}

I Marx's kapitalismeanalyse viser værdiloven sig som det fundamentale grundlag for kapitalismens bevægelseslove. Det er på dette grundlag, at Marx udvikler lovene om penge, om priser, om akkumulation, om reproduktion og om kriser. Ikke blot arbejdernes kamp imod kapitalisterne, men også stridighederne inden for arbejderklassen og inden for kapitalistklassen viser sig som betinget og begrænset af systemets egne strukturer og handlinger: Marx analyserede derfor disse kampes historiske udvikling på baggrund af disse betingende og begrænsende relationers historiske udvikling, dvs. på baggrund af værdilovens bevægelser.

Til trods for den omfattende udvikling af værdilovens bevægelser i de tre Kapital-bind, ved vi selvfølgelig at mange emner er ufuldendte, medens andre så godt som ikke er behandlet. F.eks. var det Marx's oprindelige intention at udvide den analyse, der blev fremlagt i de tre Kapital-bind med en undersøgelse af staten, udenrigshandlen, og af verdensmarkedet og krisen - hver af dem skulle behandles i et særligt bind. ${ }^{1}$ Men dette skete aldrig. I stedet måtte Engels efter Marx's død samle Kapitalens bind II og III fra en mængde papirer, varierende fra nogenlunde afpudsede udkast til blotte notater om emner der skulle videreudvikles. ${ }^{2}$ Indtil i dag er bestemte af Marx's manuskripter - om penge og om vekselkurser - endnu ikke blevet publiceret. $^{3}$

Det er sigtet med denne artikel at begynde at udfylde et af de tre hovedområder, der er opridset i det foregående: nemlig udvidelsen af værdiloven til spørgsmålet om udenrigshandel.

Men før vi tager fat på dette, er det nødvendigt at vise at dette ikke allerede er gennemført - hverken før Marx, af forfattere som David

* Oversat fra »Foreign Trade and the Law of Value« in Science and Societyefteråret 1979 og vinteren 1979-80. I oversættelsen har vi udeladt det sidste kapitel i anden del, »The Law of Value and Foreign Trade $\ll$.

1. R. Rosdolsky, Zur Entstehungsgeschichte des Marxschen 'Kapital'. Frankfurt a.M. 1968, kap. 2.

2. K. Marx, Kapitalen, bind 3 bog 1, København 1972, Engels' forord ss. 7-15.

3. K. Marx, Grundrisse, M. Nicolaus (ed.), New York 1973, forord s. 12. 
Ricardo, eller efter Marx, af de mange marxister, der har skrevet om international handel, imperialisme, ulige bytte og så videre. Vi vil derfor i det følgende først efterspore den måde hvorpå Ricardo's arbejdsværditeori giver grundlag for det berømte princip om komparative omkostninger, for det er på dette princip, at så forskellige forfattere som Ricardo, Ohlin, Samuelson og Emmanuel baserer deres analyser over varehandel og den heraf følgende internationale arbejdsdeling. Vi vil ikke blot unders $\emptyset$ ge hvilke specifikke mekanismer, som antages at give anledning til denne mærkelige lov, men også de måder hvorpå den bliver indordnet $\mathrm{i}$ både ortodokse og marxistiske teorier om udenrigshandel. Først herudfra bliver det muligt at vende tilbage til hovedopgaven, at udvikle de marxistiske love om international handel i modstilling til de ricardianske.

På grund af et sådant projekts omfang vil denne artikel blive delt i to afsnit. Den første del koncentrerer sig om afledningen af loven om de komparative omkostninger, dens efterfølgende optagelse i ortodoks teori, og dens eksplicitte eller implicitte tilstedeværelse i moderne marxistiske udenrigshandelsteorier. I anden del bruges Marx's kritik af den ricardianske værditeori til at forkaste princippet om komparative omkostninger, og Marx’s egen præsentation af værdiloven udvides til udenrigshandelen. På dette grundlag vil vi være i stand til at udvikle de fænomener der henholdsvis stammer fra strømmene af vare-, finans- og produktionskapital. Endelig vil vi være i stand til at behandle de forskellige overførsler af værdi der er forbundet med disse strømme, og bruge disse resultater til at udvikle en kritik af det ulige bytte.

\section{Ricardo's afledning af loven om komparative omkostninger}

Ricardo hævdede at det afgørende problem, som den politiske $\varnothing$ konomi stod over for på hans tid, var bestemmelsen af de love som regulerer fordelingen af det (kapitalistiske) samfunds produkt mellem de tre store klasser: dvs., loven der bestemmer »jordrentens, profittens og lønnens naturlige bevægelse. $\ll^{4}$

Men hurtigt under sit arbejde erkendte Ricardo at han ikke kunne komme videre uden en værditeori. Og denne værditeori krævede - som han også hurtigt måtte erkende - både en teori om relative priser og en pengeteori:

Før mine læsere kan forstå det bevis som jeg mener at give, må de forstå teorien om omløbsmidler og om priser .... Hvis jeg kan overvinde de den-

4. D. Ricardo, Principper fra den politiske фkonomi og beskatningen, København 1978, s. 41. 
ne hindring ved at give en klar indsigt i loven om den relative værdis eller bytteværdiens udspring vil jeg have vundet halvdelen af kampen. ${ }^{5}$

\section{Pristeorien}

Det første problem, som Ricardo formulerede, var bestemmelsen af den lov der regulerer de relative priser. Selvfølgelig var han helt opmærksom på at den umiddelbare regulator for markedspriserne var udbud og efterspørgsel; men ligesom Adam Smith før ham var han lige så vel opmærksom på at over længere tid var det uophørligt fluktuerende samspil mellem udbud og efterspørgsel selv reguleret af et mere fundamentalt princip: ens profitabilitet. Hvis profitraten i en bestemt sektor på grund af markedsforholdene stiger over den gennemsnitlige rate, så vil kapitalstrømmen tendentielt blive trukket over til denne sektor, hvilket får den til at vokse hurtigere end efterspørgslen, og presser dens markedspriser ned til et niveau som er i overensstemmelse med den gennemsnitlige profitabilitet. Omvendt vil sektorer med lav profitabilitet tendere mod at vokse langsommere end efterspørgslen, hvilket får deres priser og profitabilitet til at stige.

Den klassiske økonomi var således i stand til at vise at der bag de kontinuerligt varierende markedspriser ligger et andet system af mere fundamentale priser, der fungerer som svingningscenter for markedspriserne, og som mere eller mindre indebærer ens profitrater. I den klassiske politiske $\varnothing$ konomi blev disse regulerende priser kaldt »naturlige priser «, af Marx senere »produktionspriser «.

Alt dette var velkendt før Ricardo's tid. Hvad han selv søgte at gøre var at gå bag om produktionspriserne, for at opdage hvad der regulerede disse. Især argumenterede han for at ændringer i disse relative produktionspriser stort set er bestemt af ændringer i den relative størrelse af det totale arbejdsbehov efter de pågældende varer ${ }^{6}$ - hvert totalt arbejdsbehov er defineret som summen af den direkte arbejdstid som behøves til at producere en vare plus den indirekte arbejdstid som behøves til produktionen af dens forskellige produktionsmidler, plus produktionsmidlerne til disse produktionsmidler, osv. Efter at have udarbejdet begrundelsen for denne lov om prisændringer, antager Ricardo i de efterfølgende kapitler, at de relative produktionspriser mere eller mindre er lig med de relative mængder

5. Fra P. Sraffa's forord til 1. bind af Collected Works and Correspondence of David Ricardo, Cambridge 1962 ss. xiv-xv.

6. Ibid. 
af det totale arbejdsbehov. ${ }^{7}$ Både penge- og udenrigshandelsanalysen er gennemført på dette grundlag.

Det er ikke her muligt at efterspore logikken bag Ricardo's argumentation. ${ }^{8}$ For vores formål er det tilstrækkeligt at bemærke, at man i marxistiske termer kan sige at i forlængelse i hans Principles, forudsætter Ricardo's analyse, at produktionspriserne mere eller mindre er lig med (arbejds)værdierne.

\section{Pengeteorien}

Efter at være nået til en lov om relative priser går Ricardo videre til at undersøge årsagerne til variationerne i pengeprisernes højde.

Vi vil følge Ricardo i antagelsen af at guld er pengevaren. Så er pengeprisen på en vare dens bytteforhold med guld. Men hvis varerne stort set udveksles i forhold til (arbejds)værdierne, er pengeprisen på enhver vare dens arbejdsværdi divideret med arbejdsværdien af en enhed guld, f.eks. en ounce. Denne repræsenterer den mængde guldpenge som er $n \emptyset d v e n d i g$ for at $k \varnothing b e$ en enhed af varen: varens pengepris er lig med så og så mange ounce guld. Hver gang der er en pengevare vil der naturligvis opstå særlige navne for særlige vægte på den. I England var på Ricardo's tid f.eks. ca. 1/4 ounce guld kendt som et »pound « (£). Man sagde derfor at en vare som blev byttet for 1 ounce guld havde en pengepris på $4 £$.

I løbet af et bestemt år kan den samme guldmønt skifte hænder flere gange, idet den gennem salg af en vare bliver modtaget af en person og derefter udbetalt til en anden, når den bliver brugt til at købe en anden vare. På denne måde kan den samme guldmønt fungere som cirkulationsmiddel mere end én gang for hvert givet år. Hvis en mønt i gennemsnit skifter hænder fem gange i løbet af et år er omløbshastigheden $=5$.

Hvis vi forudsætter at den nødvendige totale arbejdstid for alle de producerede varer $\mathrm{i}$ et givet år er 40 millioner arbejdstimer, og at den totale arbejds-tid der behøves til at producere $1 £(1 / 4 \mathrm{oz})$ er $1 / 2$ arbejdstime, så vil pengeprisen på samfundets årlige output være 80 millioner.

7. Ricardo angiver at andringer i prisforholdene over en given periode tilnærmelsesvist er proportional med ændringer i det tilsvarende totale arbejdsbehov. Tilnærmelsesvis proportionalitet mellem prisforholdene og det tilsvarende arbejdsbehov er således en tilstrækkelig men ikke nødvendig betingelse for Ricardo's hovedantagelse.

8. Dette spørgsmål er udfoldet mere fuldstændigt i: Anwar Shaikh, »On the Laws of International Exchange, «som udkommer i: Growth, Profits and Proporty: Essays in the Revival of Political economy, E. J. Nell (ed.), Oxford forventet publicering i 1979. 
Hvis omløbshastigheden for mønten er fem, betyder det at der kun behøves 16 millioner guldmønter, som hver vejer $1 £(1 / 4 \mathrm{oz})$, som penge i det år.

Sådan som loven indtil nu er blevet behandlet, gælder den naturligvis kun for produktionspriser. Imidlertid ved vi fra lovene for markedspriserne at hvis udbuddet af en vare overstiger dens efterspørgsel, så vil markedsprisen på varen falde - dvs. den vil blive byttet for mindre af andre varer. Hvis denne lov også anvendes på penge fører den direkte til den slutning, at når mængden af guldmønter overstiger cirkulationens behov (den såkaldte »efterspørgsel« efter mønter) så vil »prisen « på guld falde. Men siden guld $e r$ penge, kan det ikke have en pengepris; men da det kan bruges til at købe enhver vare på markedet, kan det bogstaveligt talt siges at have i tusindvis af »varepriser «, som er de mængder af de forskellige varer som kan købes med $1 £(1 / 4$ oz.) guld. Den klassiske pengekvantitetsteori påstår derfor, at når mængden af guldmønter overstiger cirkulationens behov, så vil alle guldets »varepriser « falde. Da dette betyder at guld vil købe mindre af hver vare, er det ensbetydende med at påstå at alle pengepriser vil stige.

Indtil nu har diskussionen forudsat guldpenge. Men Ricardo generaliserer hurtigt argumentationen til at dække alle pengetyper: alt andet lige vil en forøgelse i pengeudbuddet hæve alle pengepriserne, og en formindskelse vil sænke alle pengepriser. Som vi straks skal se spiller denne pengeteori en afgørende rolle i Ricardoś udenrigshandelsteori.

\section{Den ricardianske lov om komparative omkostninger.}

Vi bemærkede tidligere at Ricardo's værditeori indbefatter en teori om relative priser og en pengeteori. I det følgende skal vi se hvorfor Ricardo's værditeori nødvendigvis giver ophav til hans berømte lov om komparative omkostninger. I den henseende er det vigtigt at indse, at det afgørende element i Ricardo's afledning af loven om udenrigshandel viser sig at være hans brug af pengekvantitetsteorien, for det er denne teori der giver den nфdvendige mekanisme til at Ricardo kan nå sit resultat. Som vi skal se i næste afsnit forkaster den neoklassiske teori med stor voldsomhed Ricardo's arbejdsteori som grundlag for priserne, men ikke desto mindre fortsætter den med at rumme forskellige teorier om pengeprisernes niveau som (for så vidt som det angår dette forhold) funktionsmæssigt svarer til Ricardo's. Det er derfor heller ikke overraskende at også den neo-klassiske teori baserer sin udenrigshandelsanalyse på princippet om komparative omkostninger. 
Lad os indlede gennemgangen af den ricardianske udenrigshandelsanalyse med at betragte to varer, klæde og vin der bliver produceret i England; der kræves 100 arbejdstimer til at producere klæde og 120 arbejdstimer til vin. Hvis der som i vores tidligere eksempel behøves $1 / 2$ arbejdstime til at producere $1 £(1 / 4 \mathrm{oz})$ guld, så vil produktionspriserne på klæde og vin ifølge Ricardo's prislov være mere eller mindre lig med deres forskellige arbejdstid i forhold til gulds. Klæde ville på hjemmemarkedet blive solgt til ca. $200 £$ og vin til ca. $240 £$.

Lad os nu betragte de to samme varer i Portugal. Vi antager at møntheden i Portugal er en escudo (e.), ca. 1/6 af en ounce guld; hvis vi antager ens arbejdstid for guld $i$ alle lande, vil det kræve $1 / 3$ arbejdstime at producere en escudo (1/6 oz.) Hvis der i Portugal bruges 90 arbejdstimer til klæde og 80 til vin, vil produktionspriserne på hjemmemarkedet være henholdsvis ca. 270 e. og 240 e.

Bemærk imidlertid at både $£$ og e. blot er forskellige nationale pengenavne på guldmængder. Hvis Englands betaling til udlandet overstiger dets indtægter herfra, dvs. det har underskud på betalingsbalancen, vil guldbarrer muligvis blive brugt til udligne forskellen. ${ }^{9}$ Da begge betalingsenheder faktisk er guldkvantiteter, og det internationale betalingsmiddel er guldbarer, kan vi forenkle fremstillingen betydeligt ved at udtrykke alle priser direkte i ounce guld. Forudsat at en ounce guld kræver to arbejdstimer, får vi følgende ricardianske opstilling for England og Portugal:

$$
\begin{gathered}
\text { ENGLAND } \\
\text { Klaede: } 100 \mathrm{t} \rightarrow 50 \text { oz. guld } \\
\text { Vin: } 120 \mathrm{t} \rightarrow 60 \text { oz. guld }
\end{gathered}
$$

\author{
PORTUGAL \\ 45 oz. guld $\rightarrow 90 \mathrm{t}:$ Klacde \\ 40 oz. guld $\rightarrow 80 \mathrm{t}:$ Vin
}

I denne udgangssituation er det klart at Portugals større produktionseffektivitet overføres direkte til en generel absolut handelsfordel. Hvis transportomkostningerne ikke er uoverkommelige vil de portugisiske kapitalister eksportere begge varer. England vil opleve et fortsat handelsbalanceunderskud, som vil blive udlignet ved afskibning af guld til Portugal.

9. I virkeligheden opererede guldstandarden med bytteforhold som kunne variere inden for bestemte grænser. Disse grænser, kaldet guld-punkter, bestemte om det var billigere at veksle indenlandsk valuta til fremmed valuta ifølge bytteforholdet eller købe guld med indenlandsk valuta og bruge guldet i udlandet. Den grundlæggende determinant for disse 'guld-punkter' var omkostningerne ved at transportere guldbarrer fra et land til et andet. 
Ifølge Ricardo's logik er det på dette sted, at pengekvantitetsteorien bliver afgørende. ${ }^{10}$ Udstrømningen af guld fra England betyder et fald i dets forsyning med penge på hjemmemarkedet, hvorved guldprisen på alle engelske varer ifølge pengekvantitetsteorien vil begynde at falde. Omvendt vil tilstrømningen af guld til Portugal hæve alle priser dér. Når dette sker vil Portugals konkurrencefordel på de internationale markeder gradvis bliver udhulet, selvom landet hvad angår effektivitet naturligvis vil have en lige så stor fordel som før. Det er blot således, at denne større effektivitet i tiltagende grad vil blive udlignet ved stigning i de portugisiske priser i forhold til de engelske.

Under denne proces vil én af de to engelske varer før eller senere blive konkurrencedygtig med den tilsvarende portugisiske. Men hvilken af dem? I effektivitetsmål vil England for begge varer altid være i et ufordelagtigt forhold til Portugal. Men når alle de engelske priser falder og alle de portugisiske stiger, vil den engelske vare med det mindste ulempe være den første til at indhente sin portugisiske rival. Hvis vi undersøger den ricardianske opstilling i tabel I, ser vi at Englands vinproduktion kun er 66 $2 / 3 \%$ så effektiv som den portugisiske rival (da der bruges 80 timer til portugisisk og 120 timer til engelsk vin), hvorimod engelsk klædeproduktion er $90 \%$ så effektiv som portugisisk. Englands mindste ufordelagtighed, dets relative fordel, er på klæde, og når de engelske priser falder relativt $\mathrm{i}$ forhold til de portugisiske, er det det engelske klæde, der først bliver konkurrencedygtigt. Det er desuden klart at hvis England har en ens ulempe i begge produktionssektorer, så vil begge engelske varer blive konkurrencedygtige på nøjagtig samme tidspunkt. Skønt handel stadig kunne finde sted under disse betingelser vil der ikke være noget bestemt grundlag for specialisering. Kun når England har forskellige ulemper ved de to varer -

10. Ricardo bruger eksemplet i tabel I til at argumentere for handelens gevinster i henhold til den komparative fordel. Hans afledning af de mekanismer, der frembringer denne specialisering er lidt forskellig fra min, men logisk set er de identiske. Til at begynde med antager han at England har en absolut fordel hvad angår klæde og at Portugal har en absolut fordel hvad angår vin, hvorfor absolut fordel og komparativ fordel her er det samme, og specialiseringen i overensstemmelse med hver medfører de samme mønstre. Han tillader så England at nå op til Portugal hvad angår vinproduktion, således at det fortsætter med at eksportere klæde men ophører med at importere vin. Handel sker således kun den ene vej, og guld flyder ud fra Portugal til England, idet det hæver alle priserne i det sidstnævnte og sænker alle priserne i det førstnævnte. (Ricardo, op.cit.) Denne mekanismes logik retfærdiggør såvel hans tidligere eksempel (det som er skitseret i tabel I), som hans erklæring om at de relative priser på de internationalt handlede varer ikke er reguleret på samme måde som de varer der kun handles på hjemmemarkedet (ibid.) Istedet for at følge logikken i sin fremstilling, svinger Ricardo på dette sted over til de konsekvenser som hans analyse får for de internationale forskelle i prisniveauerne. (ibid.). 
dvs. kun når det har en relativ fordel i en af dem - kan ricardiansk handel finde sted. ${ }^{11}$

Når England er konkurrencedygtig hvad angår klæde, begynder en gensidig handel. Dette vil forbedre Englands handelsbillede, men det vil sandsynligvis ikke fjerne underskuddet; bevægelser i prisniveauet vil således fortsat finde sted, hvorved Englands internationale position styrkes og Portugals svækkes - indtil handel på et eller andet punkt vil vare mere eller mindre $i$ balance, med hvert land som eksportør af den vare for hvilken det $n u$ har en relativ fordel. Hvis denne tilpasningsproces af en eller anden grund går for vidt, til et punkt hvor selv engelsk vin sælges billigere end portugisisk, så vil den efterfølgende guldstrøm vende bevægelserne i prisniveauet, indtil der igen er opstået en relativ fordel.

En vigtig implikation ved denne tilpasningsproces er at hvert lands internationale bytteforhold (den importmængde som kan købes med en enhed af dets eksport) til sidst nødvendigvis vil være bedre end dets hjemlige. F.eks. vil det i England være engelsk klæde der er på markedet, mens den tilgængelige vin generelt vil være importeret fra Portugal. De der er så grænseløst patriotiske, at det får dem til at insistere på engelsk vin, må betale en højere pris for den end de må for den importerede type. Derfor vil en enhed klæde, Englands eksportvare, være flere enheder portugisisk end hjemlig vin værd, fordi den sidstnævnte koster mere. Noget tilsvarende gør sig gældende i Portugal, hvor landets eksport, vin, vil flere enheder engelsk klæde end portugisisk klæde værd, fordi det engelske klæde ganske enkelt er billigere.

Den slutning som lige er fremsat om hvert lands bytteforhold, er ofte blevet brugt som et bevis på at hver nation alt i alt tjener på handel. Den udsiger således at England kan få mere vin for dets klæde gennem handel end det kan få på hjemmemarkedet: handel er almindeligvis fordelagtig. Skønt Ricardo er omhyggelig med at aflede handelslovene på grundlag af deres profitabilitet for kapitalisterne, opgiver han klassebegrebet når han går over til handelens effekter; her forfalder han til et begreb om nation som en helhed. Det er selvfølgelig ubestrideligt at nationsbegrebet både er gyldigt og nødvendigt på et eller andet analyseniveau; nationer eksisterer virkeligt, og deres gensidige påvirkning er en reel proces. Men at påstå at handel er til fordel for nationen som en helhed er ganske enkelt det samme som at påstå, at »hvad der er godt for General Motors er godt for USA.« Kapitalister påtager sig handel fordi de kan opnå større profitter på denne

11. I den neo-klassiske fremstilling sker sammenligningen på prisforholdene på klæde og vin i hvert land, og ikke på produktionseffektiviteten. Men konklusionerne er de samme. 
måde; det er altid dem som snupper gevinsten. Selv hvis denne kapitalistgevinst skulle blive overført til arbejdere i det ene eller andet land, hvilket absolut ikke er givet ud fra den forudgående analyse, kan man blot sige at i dette tilfælde er handel også til fordel for en særlig gruppe af arbejdere. Det er ikke muligt at reducere de fundamentale antagonistiske klasseforhold til nationen som en helhed's blide homogenitet. Kristne er ikke i stand til at råbe hurra for løverne, så længe begge parter er indskrevet til at optræde i Kolosseum.

\section{Moderne afledninger af loven}

Det skulle være indlysende fra den forangående afledning, hvor afgørende den »rigtige « slags pengeteori er for afledningen af loven om de komparative omkostninger. Enhver pengeteori som overfører det tilbagestående lands handels underskud i udgangspunktet til et faldende prisniveau (et fald i forhold til prisniveauet i det udviklede land) vil kunne gøre kunststykket. Det er derfor nødvendigt at fremføre et par bemærkninger om de moderne teorier om pris-niveauet og deres rolle i moderne afledninger af komparative omkostninger.

De grundlæggende principper som Ricardo lagde frem forbliver stort set uberørte i de moderne versioner af udenrigshandelsteorien. Men de adskiller sig fra Ricardo hvad angår pristeorien, og i mindre omfang hvad angår formuleringen af de specifikke mekanismer, hvormed der fremkaldes specialisering svarende til de komparative omkostninger.

Hvad angår pristeorien erstatter den neoklassiske økonomi Ricardo's totale arbejdsbehov som prisregulator med forestillingen om at prisen på en vare er bestemt af de varer som nationen som en helhed må opgive for at kunne producere en ekstra enhed af den pågældende vare. Da dette begreb om omkostninger-som-opgivne-muligheder kun har mening når alle ressourcer er fuldt udnyttet, finder den neoklassiske teori det nødvendigt (og meget bekvemt) også at forudsætte fuld udnyttelse af alle ressourcer. Med udgangspunkt i en eller anden given fond af ressourcer $i$ et land, og ved antagelse af fuld udnyttelse af denne begyndelsesfond, vil de relative priser fremstå som bestemt i fællesskab af teknologistrukturen (som eksemplificeres gennem nations produktionsmulighedskurve) og preferencestrukturen (som eksemplificeres af varerne indifferenskurver).

Problemet i denne generelle beskrivelse er at næsten ethvert resultat kan afledes af passende udbuds- og efterspørgselskombinationer (produktionsmuligheder og forbrugerpreferencer). Ligesom alle næsten-taotologier er 
den i overensstemmelse med så godt som alt, hvorfor den næsten ikke kan forklare noget. Som resultat heraf er den dominerende forklaring på udenrigshandlens aktuelle mønstre, Heckscher-Ohlin-Samuelson modellen, nødvendigvis en meget mere specifik konstruktion, med meget mere bestemte resultater.

Medens Ricardo lokaliserede mønstret for international specialisering i de internationale forskelle i de relative omkostninger, så forsøger Hecksher-Ohlin-Samuelson formuleringen at gå et skridt videre og binde disse (rensede) relative omkostninger til en enkelt dominerende variabel: den givne nationale »kapital- og arbejdsfond «. For at kunne gøre dette, antages det $\mathrm{i}$ modellen at forbrugere $\mathrm{i}$ to forskellige regioner af verden i det væsentlige er ens. Endnu mere overraskende er antagelsen, at en given vare produceres under identiske produktionsbetingelser i begge regioner. ${ }^{12}$

Antagelsen angående forbrugerne udelukker forskelle i efterspørgsel mellem to regioner (f.x. den udviklede kapitalistiske verden og Den tredie Verden), som en forklaring på relative omkostningsforskelle. Men endnu mere vigtigt er det at antagelsen af identiske produktionsmuligheder fjerner underudvikling overhovedet - og med den problemet om absolut fordel og ulempe - som forklaring på relative omkostningsforskelle og derfor som forklaring på handelsmønstrene.

Det eneste der forbliver tilbage er forskellene mellem de nationale »kapital- og arbejdsfonde«. Her fremføres det, at regioner som er relativt kapital-rigelige (dvs. som har en relativ større fond af kapital end af arbejde) vil være i stand til at producere kapitalintensive varer forholdsvist billigere end de arbejds-rigelige regioner. Omvendt vil den arbejds-rigelige region naturligvis have en komparativ omkostningsfordel ved produktionen af arbejds-intensive varer. Heraf følger at den kapital-rigelige region (den udviklede kapitalistiske verden) ud fra effektivitetshensyn og til gavn for verden som en helhed skal specialisere sig i kapitalintensive (forarbejdede) produkter, og eksportere dem til gengæld for de arbejds-intensive (primære) produkter fra den arbejds-rigelige (underudviklede kapitalistiske) region. Med andre ord er accept af og tilpasning til de eksisterende forskelle mellem udviklede og underudviklede kapitalistiske regioner nyttigt set fra verden som en helhed. Stakkels Ricardo som kun turde påstå at international ulighed er det bedste af alt. Det er ikke mærkeligt at en så vidunderlig konstruktion som denne hurtigt også er blevet anvendt til at retfærdigg øre og lovprise andre former for ulighed. F.x. betragter Gary Becker ægteskab som en »handels-kontrakt« mellem mænd og kvinder,

12. C.P. Kindleberger, International Economics, Homewood, Illinois 1973, kapitel 4. 
som kan analyseres præcist på grundlag af Hecksher-Ohlin-Samuielsonmodellen. Jo større generel forskel der er mellem mænd og kvinder (dvs. jo større omfang af institutionaliseret sexisme), jo større gevinst giver handlen, og jo stærkere er båndene der holder de gifte sammen. ${ }^{13}$

Som regel henvises der ikke i de moderne fremstillinger af loven om de komparative omkostninger til de faktiske mekanismer, ifølge hvilke loven sætter sig igennem. Vægten ligger så godt som udelukkende på de handelsgevinster, der kunne opnås, hvis handelen var baseret på komparative omkostninger; men da disse modeller også skal beskrive faktiske mønstre i handelen, gøres ikke desto mindre »den implicitte antagelse, at den justering af pengeløn og prisniveauer eller bytteforhold, der er $n \phi d v e n d i g$ for at bevare international monetær stabilitet, også foregår i virkeligheden... « ${ }^{14}$ På denne måde hviler de moderne afledninger af komparative omkostninger på hvad der grundlæggende set er varianter af Ricardo's mekanisme: i alle tilfælde kræver den ønskede løsning pengevariable (prisniveauer og/eller bytteforhold) for at tilpasse sig på en sådan måde, at enhver eksisterende absolut fordel bliver til en komperativ. Følgelig gælder det for alle udgaverne, at når Englands absolutte lavere effektivitet og de heraf følgende oprindeligt højere produktionsomkostninger er givet, må det deraf resulterende handelsunderskud på en eller anden måde bevirke en forudsat sænkning af de engelske priser, mens Portugals handelsoverskud må føre til en fortsat stigning i de portugisiske priser - indtil hvert land på et eller andet tidspunkt har en omkostningsfordel på kun én vare.

Kritikken af de komparative omkostninger kræver følgelig at vi modstiller fire grundlæggende teorier om prisniveauet: Hume's betalingsstrøm-udgave af kvantitetsteorien (Ricardo), »Cashbalance « udgaven af kvantitetsteorien, den keynesianske prisfastsættelse ved hjælp af højden af pengelønninger, samt Marx's pengeteori. For at kunne gøre dette må vi have en form for fælles grundlag.

13. G. Becker, »A Theory of Marriage, Part I Journal of Political Economy, vol 81,4, juli-august 1973; »A Theory of Marriage, Part II«, Journal of Political Economy, vol 82,2, marts-april 1974. Det beviser at sexisme både er rationelt og effektivt: Mænd og kvinder bevæger sig ind på ægteskabsmarkedet med forskellige »begyndelsesfonde« bestående af hjemme-kapital og markeds-kapital; almindeligvis er mændene relativt bedre »udstyret « med markeds-kapital, og kvinderne med hjemmekapital; herudfra specialiserer de sig så til deres gensidige fordel i henholdsvis markeds- og hjemmeaktiviteter. Dog er mulighederne i denne fantastiske analyse ikke udtømt med Becker's brug af den. Hvad med sorte og hvide? Det er helt sikkert at der stadig er et arbejde at udføre.

14. H. Johnson: »International Trade: Theory«, International Encyklopedia of the Social Sciences (IESS), David L. Sills, editor, (New York, 1968, Volume 8 s. 84. 
Her er det et held, at hovedparten af den internationale handels historie og følgelig det meste af dens teori har været domineret af ædle metaller som målestok for penge, både nationalt og internationalt. ${ }^{15}$ Således finder vi altid et fælles teoretisk grundlag i diskussionerne af teorierne om international handel - de bygger på den såkaldte guldstandard som forudsætning. Ved at stille forskellige teorier med dette som grundlag op imod hinanden, kan vi adskille forskelle i teorierne fra forskelle af mere formel art. Og eftersom hverken de ricardianske eller de neoklassiske versioner af loven om de komparative omkostninger påstår at være afhængige af nogen særlige former for penge, er guldstandarden gyldig fælles grund. Og det i den grad, at den neoklassiske behandling af justeringsmekanismen under guldstandard reelt er identisk med Ricardo's:

»Justeringsmekanismen under guldstandard (...) var mere eller mindre automatisk, forstået på den måde, at centralbankerne forventedes at reagere på udstrømning og indstrømning af guld ved henholdsvis mere og mindre restriktiv pengepolitik, som så ville påvirke pris- og lønniveauerne, således at de sænkedes i landene med handelsunderskud og forhøjedes i landene med overskud. Disse prisændringer skulle derefter flytte udgifter fra lande med overskud til lande med underskud og således reducere og muligvis helt fjerne uligvægten (...) Teorien er i grove træk korrekt, selvom dens praksis er blevet noget overforenklet. $\ll^{16}$

I de neoklassiske diskussioner behandles guldstandarden som teoretisk set ensbetydende med eksistensen af faste bytteforhold. Følgelig får vi fra det modsatte teoretiske synspunkt, der ikke anerkender faste bytteforhold, at vide, at de helt variable bytteforhold udelukkende bliver bestemt gennem de forskellige nationale valutaers relative efterspørgsels- og udbudsforhold. Her hævdes det, at det er muligt for hvert land at have et fuldt ud uafhoengigt pengesystem. ${ }^{17} \mathrm{I}$ dette tilfælde er prisniveauerne i hvert land isoleret imod påvirkninger udefra, og alle justeringer foregår gennem bytteforholdet. I et tilbagestående land indebærer et handelsunderskud en

15. I følge de fleste fremstillinger er denne periode dominerende i kapitalismens historie op til i det mindste 1914, og undertiden til 1960'erne. Under alle omstændigheder fungerer de ædle metaller i den betragtede periode suverænt som internationale betalingsmidler; dette udelukker på ingen måde fænomener så som pengetegn og kreditpenge. Selvom jeg ikke her vil udvikle de forskellige former for penge, kan analysen udvides til at omfatte pengetegn og kreditpenge baseret på pengevaren (guld, sølv etc.)

16. R.A. Mundell »Balance of Payments «IESS, op.cit.ss. 8-9.

17. L.B. Yeager International Money Relations: Theory, History and Policy, New York 1966, s. 104. 
nedskrivning af landets valuta, som gør importerede varer relativt dyrere indenlands og eksporterede varer relativt billigere udenlands. Da denne proces ikke antages at være underlagt nogen begrænsninger, vil det variable bytteforhold på et eller andet tidspunkt finde et niveau, som gør de komparative forhold til en realitet.

Vi kan ikke nøjere overveje fortræffelighederne ved disse forskellige afledninger, førend vi har undersøgt Marx's pengeteori. Men det er værd på dette sted at bemærke, at det er helt fejlagtigt at behandle eksistensen af en guldstandard som ensbetydende med en eller anden teoretisk antagelse om faste bytteforhold. Guldstandarden var i sin praktiske funktion et system af variable bytteforhold, hvis bevægelser var begranset af de omkostninger, der var forbundet med at transportere guld. Dette bet $\varnothing$ d, at hvad angik de »normale « variationer i handelen virkede guldstandarden som om den udgjorde et system af fuldt fleksible bytteforhold. På den anden side betød det, at forsåvidt det drejede sig om systematisk uligevægt, nåede bytteforholdet snart en af de to grænser, hvorved det blev billigere at betale gæld ved at sende guld direkte: på denne måde virkede guldstandarden ligesom et system med faste bytteforhold. Den ortodokse teoretiske antagelse, at der findes to uafhængige diametrale modsætninger, faste og variable bytteforhold, har således sin oprindelse i ensidige (og følgelig falske) abstraktioner omkring den virkelige proces. Dette vigtige punkt vil vi senere vende tilbage til.

\section{Ortodoks og marxistisk kritik}

Loven om komparative omkostninger har uanset sin form altid været forbundet med forsvar for frihandel: Ricardo's egen udvikling af dette princip var i virkeligheden en del af hans polemik imod kornlovene (hvilke skulle hindre den frie import af billigt korn til England), og fra det tidspunkt har frihandelstilhængere af alle arter baseret deres egne argumenter på Ricardo's. Det er følgelig ikke overraskende at konstatere, at kritikernes første angreb har været sat ind ikke så meget imod den del af loven, som argumenterer for, at handelsmønstret vil være afhængig af de komparative omkostninger, som imod den tese, at frihandel er effektiv, til fordel for begge parter og et gode for verden som en helhed.

Vi kan, bortset fra de følgende bemærkninger, ikke her diskutere de ortodokse kritikere af loven synderlig detaljeret. Disse kritikere kan i almindelighed opdeles i tre kategorier. Først de (som Graham, Keynesianerne osv.) som forsøger at modificere lovens grundlag i større eller mindre grad 
for at kunne modgå den med teoretiske eksempler. ${ }^{18}$ Til trods for deres tilsyneladende modstand mod loven, accepterer denne type af kritik implicit (og ofte eksplicit) loven som varende gyldig på sit eget grundlag. Det er derfor ikke overraskende, at disse former for kritik sædvanligvis betragtes ikke som forkastelse af loven om de komparative omkostninger, men snarere som videreudviklinger; karakteristisk nok fremstilles doktrinen om de komparative omkostninger i neoklassiske lærebøger som det grundlæggende princip, international handel hviler på, hvor de foranstående typer af kritik er udvidelser og konkretiseringer af det.

For det andet findes der empiriske studier som synes at forkaste loven; således de berømte studier af Leontief og Arrow-Chenery-MinhasSolow. Begge disse studier sår alvorlig tvivl om den empiriske relevans af Hecksher-Olin-Samuelson-modellens antagelser og forudsigelser. Men uanset hvor deprimerende disse resultater er for fortalerne for denne model, har de ikke megen relevans for selve princippet om komparative omkostninger, for (som vi allerede har bemærket) begynder denne model med at antage det ricardianske mønster af specialisering i følge komparative omkostninger, hvorefter den forsøger at forbinde dette mønster med det særlige »faktor-fonde «, som de berørte nationer har. I bedste tilfælde overskærer de empiriske og teoretiske paradokser, som denne slags studier har affødt, blot det tilstræbt etablerede led mellem de forskellige nationale faktorfonde og mønstret i handelen. De efterlader den ricardianske lov urørt.

Endelig kommer vi til de kritikere, som angriber loven for ikke længere at gælde, fordi en eller flere af dens præmisser ikke længere holder i verden af i dag. Her finder vi, at den empiriske kritik af loven og i særdeleshed at frihandelens effektivitet grunder sig på moderne udviklingstræk såsom fraværet af løn og prisfleksibilitet, afskaffelsen af guldstandarden, konkurrencens bortdøen og den systematiske regeringsindblanding ${ }^{19}$. Til vort formål er det tilstrækkeligt at bemærke, at denne historiske, ortodokskritiske skole (der, som vi skal se senere, har marxistiske sidestykker) implicit accepterer loven som gyldig, når dens præmisser - især de, der har

18. De ortodokse kritikere diskuterer jeg i større udstrækning $\mathrm{i} »$ On the Laws of International Exchange « (se note 8). Videre giver A. Emmanuel i introduktionen til sin bog Unequal Exhange: A Study of the Imperialism of Trade, New York 1972 et nyttigt og oplysende rids over de ortodokse kritikker af loven om de komparative omkostninger.

19. M. Barrat-Brown, The Economics of Imperialism, New York 1974. I denne bog fremlægger Barrat-Brown forskellige argumenter der bebrejder »sektor monopoler og obstruktionelle principper« (s. 32), post-kolonialistisk nationalisme og selvfremkaldt autarki« (s. 35), »fagforenings-aktioner «, og uligevægten i »forhandlingsstyrken « mellem udviklede og underudviklede lande (s. 233) for den historiske uanvendelighed af frihandels-argumenter. 
at gøre med konkurrencekapitalismen - kan anses for holdbare. På dens eget grundlag (som i dette tilfælde antages at indebære en særlig historisk epoke) accepteres loven som gyldig.

For at opsummere finder vi, at hvad angår den ortodokse kritik (hvad enten den er teoretisk, empirisk eller historisk), dukker de grundlæggende principper i doktrinen om de komparative omkostninger relativt uskadte frem. Vi vender os derfor til de kritikker, der er fremført fra marxistisk hold.

Når vi husker Marx's udtømmende behandling af Ricardo's værditeori, kunne man tro, at marxisterne for længe siden ville have udvidet hans analyse $\mathrm{i}$ den ene eller den anden retning for at behandle den ricardianske lov om komparative omkostninger. Mærkeligt nok er dette ikke tilfældet; emnet tages sjældent op ${ }^{20} \mathrm{og}$ når det sker, anerkendes Ricardo's fors $\emptyset \mathrm{g}$ på at fastlægge grænserne for det internationale bytte kun implicit ved at en af hans centrale konklusioner accepteres: værdiloven regulerer byttet inden for en konkurrencekapitalistisk økonomi, men ikke imellem sådanne.

Hvorfor denne talende tavshed?

Til dels skyldes den, at Marx kun i ringe omfang henviser til spørgsmålet omkring udenrigshandelen - hvad der uden tvivl skyldes hans eksplicitte intention om at behandle dette problem i et særligt bind, der skulle følge efter Kapitalen. Men denne tavshed fra Marx's side er kun en del af forklaringen på marxisternes ambivalens i forhold til dette emne. En anden del af forklaringen ligger i den kendsgerning, at siden offentliggørelsen af Lenins Imperialismen som kapitalismens højeste stade, er det blevet en marxistisk latitude at fastslå, at kapitalismen har nået sit monopolistiske stadium. ${ }^{22}$ Hvad angår monopol, er det almindeligt accepteret af såvel marxister som ikke-marxister, at lovmæssighederne omkring prisdannelse må forlades: ${ }^{23} \gg$ Fra et analytisk synspunkt er det mest alvorlige aspekt ved monopolet, at forskellene mellem monopolpris og værdi ikke er underlagt nogen almindelige love... ${ }^{24}$ Hvad der derfor bliver tilbage, er den kapitalistiske vareproduktions grundlæggende sociale forhold, og imod disse forskellige udtryksformer vender teorien om monopolkapitalen sig.

20. Jvf. E. Mandel, Marxist Economic Theory, Vol I-II, New York 1968, og P. Sweezy, The Theory of Capitalist Development, New York 1962.

21. Sweezy, op.cit. s. 289.

22. V.I. Lenin, Imperialismen som kapitalismens højeste stade, København 1978.

23. Sweezy, op.cit. ss. 270-271.

24. Ibid. s. 54. 
Når lovmæssighederne omkring den almindelige prisdannelse én gang er smidt væk, følges de naturligvis af lovene for international prisdannelse. I stedet retter opmærksomheden sig mod den inden- og udenlandske rivalisering mellem de gigantiske monopoler, mod deres politiske forbindelser med forskellige kapitalistiske stater og modsætningerne og konflikterne mellem disse stater indbyrdes - kort sagt, mod »imperialismen « som et aspekt ved monopolkapitalismen. Værdiloven forsvinder tilbage i historien, ligesom konkurrencekapitalismen.

Det ligger uden for målet med denne artikel at forsøge en egentlig oparbejdelse af et marxistisk begreb om koncentration og centralisering (i modsætning til monopol) for at imødegå ovennævnte synspunkter. Dog må det bemærkes, at selvom man skulle acceptere disse synspunkter, vil det på ingen måde fjerne den ambivalens, der er imellem marxister, med hensyn til Ricardo's lov, ej heller vil det løse de stadigt opdukkende uenigheder omkring transformationsproblemet, lønteorien etc.; i stedet undviges de blot. Ligesom deres ortodokse modstandere lader disse marxistiske kritikere loven om de komparative omkostninger stå urørt - i det mindste forsåvidt angår konkurrencekapitalismen.

I de senere år er dette problem igen kommet i brændpunktet på grund af Arghiri Emmanuels udfordrende nye bog, Det ulige bytte: et studie $i$ handelsimperialismen ${ }^{25}$. I denne bog vil Emmanuel omstyrte den ondartede teori om de komparative omkostninger ved at angribe det som han anser for en af dens grundlæggende antagelser - kapitalens manglende mobilitet mellem landene og regionerne.

Emmanuel begynder med at fastslå at Ricardo's analyse af udenrigshandelen fremføres ud fra antagelsen om, at kapital og arbejde på verdensplan ikke er mobile. Dette er så at sige betingelserne for den »rene « udenrigshandel, eftersom det i dette tilfælde kun er varer (og ikke kapital og/eller arbejde,) der bevæger sig mellem nationerne.

På dette dens oprindelige grundlag accepterer Emmanuel Ricardo's lov. ${ }^{26}$ Men, fremhæver han, verden af i dag er anderledes, for selvom arbejde stort set ikke er mobilt på verdensplan, er kapital temmelig mobil. ${ }^{27}$ I dag resulterer arbejdskraftens relative mangel på mobilitet i store og permanente forskelle i lønninger mellem de udviklede og de underudviklede dele af den kapitalistisk dominerede verden, hvorimod den relativt mobile kapital tenderer imod en faktisk udligning af profitraterne

25. Emmanuel, op.cit.

26. Ibid. ss. XXXIII-XXXIV.

27. Ibid. s. XXXIV. 
verdensdelene imellem. Det er derfor Emmanuels påstand, at hvor loven om de komparative omkostninger fortsat bestemmer de internationale mønstre $i$ handelen og specialiseringen (og dermed også den internationale arbejdsdeling), afstedkommer den moderne kapitals mobilitet en række helt nye og uforudsete følgevirkninger af denne lov. I særdeleshed vil profitraterne, mellem verdensdelene, på grund af kapitalens manglende mobilitet tendere mod at være højere i de underudviklede områder end i de udviklede, fordi lønningerne vil have en tendens til at være meget lave i de underudviklede områder. Hvis profitraterne nu udlignes gennem kapitalens internationale mobilitet, vil profitraterne blive lavere i de underudviklede og højere i de udviklede områder. Heraf følger, at profitterne (merværdien) vil blive overført fra de førstnævnte til de sidste. Eftersom profitterne er en vigtig kilde til vækst, er overførslen af profitter bort fra de underudviklede områder på samme tid en reduktion i den vækstrate, der kunne have været, hvis der ikke havde været idenlandske kapitaler. Denne effekt, som sammenligner hvilke profitter, der kunne have været mulige, hvis kapitalen ikke havde været mobil, med de virkelige profitter, der er resultat af kapitalens faktiske mobilitet, er helt forskellig fra spørgsmålet om hvorvidt de faktiske profitter de udenlandske kapitaler opnår i de underudviklede områder geninvesteres her eller føres ud af landet. I det omfang de føres ud, ville spot blive føjet til skade. Men hovedproblemet forbliver selve overførslen, som Emmanuel kalder det ulige bytte (i snæver forstand).

På dette sted vil vi ikke gå i dybden med en undersøgelse af Emmanuels analyse. For vort formål rækker det at notere os to forhold i denne debat. For det første, at Emmanuel helt eksplicit accepterer Ricardo's lov på dens oprindelige grundlag og ovenikøbet bibeholder den som grundlaget for den internationale arbejdsdeling i sin efterfølgende udledning af det ulige bytte. I denne betydning forbliver den ricardianske lov basis for Emmanuels nye overbygning. For det andet lykkes det for Emmanuels kritikere at undgå to centrale spørgsmål, som hans studier stiller (selvom mange af de marxistiske kritikpunkter til den problematik, der ligger under hans argumenter, er meget sigende). Først og fremmest: er det virkelig sandt (således som mange marxister synes at tro) at Ricardo's lov om de komparative omkostninger på det abstraktionsniveau, Marx bevæger sig på i de tre kapitalbind, er den internationale form for Marx's værdilov? For det andet: er det sandt (således som Emmanuel påstår), at når kapitaleksporten bliver fremtrædende, transformeres den marxske lov om international værdi til Emmanuels lov om det ulige bytte?

Når de stilles på denne måde, har spørgsmålene nøjagtig den samme teoretiske status som en hvilkensomhelst anden lov, der udvikles af 
Marx i Kapitalen. Marx blotlægger kapitalismens struktur på basis af dens »ideelle « form, den frie konkurrence, netop fordi det er denne form, der lader systemets immanente love komme bedst til udtryk. Det er på dette grundlag, at Marx udleder udbytning, kriser, koncentration og centralisering og en mængde andre fænomener, der er karakteristiske for kapitalismen. Undrer det derfor ikke, at selv om det frie og lige bytte inden for en kapitalistisk nation giver grundlag for alle disse fænomener, så synes det ikke at være tilfældet når det finder sted mellem kapitalistiske nationer? Hvordan kan det være, at når Marx udleder den ulige udvikling inden for en kapitalistisk nation på grundlag af den frie konkurrence, så må marxister almindeligvis søge tilflugt i monopoler for at forklare den ulige udvikling imellem kapitalistiske nationer? Disse spørgsmål vil vi se på i det følgende.

\section{I. del: resume og konklusion.}

Måske er den såkaldte lov om de komparative omkostninger det mest permanente element $\mathrm{i}$ analysen af den internationale handel; som vi har set er den almindeligvis blevet anerkendt af ortodokse økonomer såvel som marxister som værende gyldig på sit eget grundlag. I alle dens forskellige forklædninger har denne lov hævdet, at når der foregår handel mellem kapitalistiske lande, fornægtes indbyggede uligheder. Dog behøver intet land, hvor lavtstående det end er, at frygte handelen, for ligesom den borgerlige retfærdighed er handelen blind for standsforskelle. Det er i det mindste, hvad man påstår!

Men det viser sig, at bortset fra den overflod af beviser på de såkaldte fordele ved specialisering, ligger sagens kerne i den påstand, at den internationale handels virkelige funktion er at frembringe en sådan specialisering. Og den automatiske mekanisme som tilsyneladende sætter dette i værk, fastslog vi, var de forskellige ortodokse teorier om prisniveauet.

Vi fortsatte så med at undersøge udviklingen af princippet i de komparative omkostninger i deres originale (og grundlæggende set uændrede) form: David Ricardo's. Først når dette var gjort, kunne vi præsentere og analysere moderne udledninger af loven. Det var vigtigt at vise, at den såkaldte lov var et logisk resultat af forbindelsen mellem Ricardo's værditeori og hans pengeteori. Dette gjorde det muligt for os at fastslå, at kritikken af loven skulle sættes ind over for dens forudsatninger - ikke over for loven selv.

I anden del af dette papir vil vi fokusere på Marx. I hans analyse af Ricardo giver Marx os de nødvendige kritikpunkter til Ricardo's værdi- og pengeteori. Ydermere behandler han i sit eget arbejde disse emner i sin 
udvikling af værdiloven. Vi vil også præsentere Marx's egen behandling af værdi, pris og penge. Dette har en dobbelt følgevirkning: hans kritik af forudsætningerne for den såkaldte lov om de komparative omkostninger vil give os grundlag for en kritik af loven selv; og hans egen udvikling af værdiloven vil give os basis for adækvat behandling af lovene for det internationale bytte. Når dette er gjort, vil det vise sig, at loven om de komparative omkostninger vil være umulig, netop på dens eget grundlag. Fremfor som Ricardo at finde at Portugal og England hver for sig vil ophøre med at specialisere sig i en af de to produktioner - til trods for Portugals absolutte overlegenhed inden for begge - vil vi finde, at Portugal nødvendigvis vil eksportere begge varer. England, det underudviklede kapitalistiske land i dette eksempel, vil slutte med et permanent handelsunderskud, der dækkes ind ved guldoverførsler og/eller kortfristede lån. En sådan handel vil alt andet lige på et eller andet tidspunkt bryde sammen.

Når dette resultat fremsættes på den adækvate måde, kan vi sige: frihandel vil sikre, at de underudviklede kapitalistiske områder enten må begrænse deres importbehov til det lave niveau, deres eksport kan bære, eller de vil konstant have underskud og være i permanent gæld. Det er absolutte og ikke komparative fordele, som styrer handelen.

Dette indebærer en udvidelse af Marx's værdilov (som selvfølgelig indeholder en pengeteori) til også at omfatte det internationale varebytte. Men som Marx påpeger, er disse varer kapitalistisk producerede varer, de er de forskellige nationale kapitalistisk producerede varer, de er de forskellige nationale kapitalers vareform. Som sådan medfører byttet af varekapital landene imellem kimene til andre former for international kapital, såsom finanskapital (udenlandske lån) og produktiv kapital (direkte investeringer).

Spørgsmålet om de direkte investeringer er særligt vigtigt, da analysen af disse spiller en så vigtig rolle $\mathrm{i}$ de forskellige teorier om handel. For eksempel mener den ortodokse teori, at de direkte investeringer er et middel til at bygge bro over svælget mellem de rige og fattige kapitalistiske lande, fordi de overfører opsparing fra de udviklede til de underudviklede lande. Marxistiske teorier har på den anden side traditionelt afledt de mest slående træk i den ulige internationale udvikling fra eksporten af produktiv kapital; i sin teori gør Emmanuel for eksempel kapitaleksporten til altafgørende for den ulige udvikling, eftersom det er gennem den produktive kapitals mobilitet at profitraterne udlignes.

Men de fleste af disse analyser af de direkte investeringer er baseret på en accept af Ricardo's lov om de komparative omkostninger. Denne lov er det grundlag, som analysernes overbygning er bygget på. Da denne 
artikels hovedpointe er at omstyrte denne lov og derefter finde, at mange af de fænomener i den verdensomspændende ulige udvikling, der tidligere er blevet henført til kapitaleksporten, kan henføres til varehandelen alene, vil det på det punkt blive bydende nødvendigt at udvide analysen til også at omfatte virkningerne af de direkte investeringer.

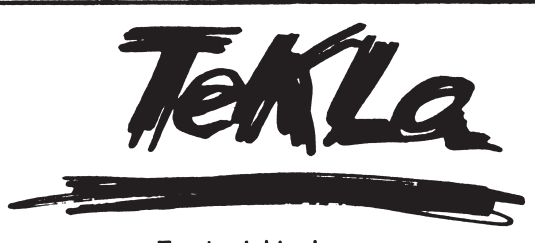

Teori och klasskamp

TEKLA nummer 10 är nu utkommen. Numret handlar om marxism och naturvetenskap och innehåller följande artiklar:

Tor Nørretranders: Kapitalistisk naturvetenskap?

David Dickson: Vetenskap och politisk hegemoni under 1600-talet

Ola Tunander: $\quad$ Produktivkrafternas långa marsch och arbetarklassens emancipation

Joachim Retzlaff: Om Ernst Blochs naturuppfattning. Några anteckningar

Ernst Bloch: $\quad$ Exkurs över Engels försök "Naturens dialektik".

Nils Hybel: $\quad$ Om Otto Ullrichs nyreformistiska teori

Numret kostar 15 :-. Prenumeration för 4 nummer: 50 :-

TEKLA, pg. 112734 - 9. Box 1049, 22104 Lund. 


\section{Anden del}

I denne artikels første del gennemgik vi afledningen af Ricardo's lov om komparative omkostninger og undersøgte dens indflydelse på både ortodokse og marxistiske teorier om international handel. I denne anden del af artiklen vil vi udlede de tilsvarende marxistiske udenrigshandelslove og vise at de igen giver anledning til mange fænomener som ofte forkert tilskrives international monopolmagt og/eller ulige bytte.

\section{Marx's udvikling af lovene for kapitalistisk bytte.}

\section{Vardi, pris og profit.}

I Kapitalens bind I og II udvikler Marx den indre forbindelse mellem værdi og penge-pris (værdiform) ud fra den forudsætning at svingningscentret for markedspengepriserne er direkte proportionalt med værdierne (direkte priser). På dette grundlag er han i stand til at vise, at arbejdskraftens værdi bestemmer og regulerer pengelønningerne, og at merværdi danner grundlaget for pengeprofit.

I bind III bliver profitkategorien yderligere konkretiseret ved at der tages hensyn til udligningen af profitraterne på tværs af brancher og til dannelsen af en almen profitrate. Dette nødvendigg $\varnothing$ r igen en transformation i vardiformen fra direkte pengepriser til produktionspriser. Disse sidste priser fremtræder nu som de virkeligt regulerende priser, det virkelige svingningscenter for markedspriserne. Ifølge Marx's udledning vil en vares produktionspris være lavere eller højere end dens direkte priser alt efter om branchens organiske sammensætning er højere eller lavere end den gennemsnitlige organiske sammensætning i samfundet som sådan.

Det er her at vi når frem til det berømte transformationsproblem, hvorom der har været skrevet meget og forstået lidt. Inden fra denne artikels rammer er det ikke muligt at udfolde transformationsproblemet $i$ alle detaljer. Dette har jeg gjort mere omfattende andet steds. ${ }^{28}$ For vores formål her er tre aspekter af betydning. For det første, at den procedure hvormed Marx transformerer direkte priser også kan ses som det første skridt i en successiv beregningsprocedure af de faktiske produktionspriser ${ }^{29}$ Det medvirker til etablering af en frugtbar matematisk forbindelse mellem

28. A. Shaikh, »Marx's Theory of Value and the 'Transformation Problem' «, in The Subtle Anatomy of Capitalism, Jesse Schwartz, ed., Santa Monica, California 1977, ss. 106-139.

29. Ibid. ss. 130-133. 
de produktionspriser som fremkommer gennem Marx's procedure og yderligere udviklede produktionspriser. For det andet at det kan vises (i det mindste i tilfælde af tre produktionsafdelinger) at i hver branche afviger både de af Marx udviklede produktionspriser og de herudover videre udviklede produktionspriser i samme retning i forhold til branchens direkte priser. ${ }^{30}$ Endelig at det kan vises at den transformerede pengeprofitrate er direkte proportional med værdi-profitraten. Skønt de to ikke behøver at være lige i størrelse, kan det nøjagtigt siges at den første er transformeret fra den sidste, og i al væsentlighed underlagt den samme bestemmelse. $^{31}$

For de fleste analyser er kendskab til de oven for anførte sammenhænge almindeligvis tilstrækkelig. Ud fra en implicit underforståelse af den oven for nævnte sammenhæng mellem de af Marx udviklede produktionspriser og deres videreudviklede form, har jeg derfor i denne artikel kun brugt direkte priser og produktionspriser som de er udledt af Marx.

\section{Pengeteorien.}

Hvis fordelingen af det samfundsmæssige arbejde i enhver periode er sådan at de producerede varer svarer til de forskellige sociale behov, vil udbud være lig med efterspørgsel, og varernes penge-priser vil være lig med deres »regulerende « priser - direkte priser, hvis vi forudsætter udveksling i forhold til værdierne, produktionspriser på et højere analyseniveau. I begge tilfælde, er det omfanget af arbejdstid som bestemmer disse regulerende priser.

Hvis fordelingen af arbejde på den anden side ikke er i overensstemmelse med de forskellige sociale behov, så vil varernes markedspriser afvige fra deres reguleringspriser, og for at reducere forskellene mellem markeds- og reguleringspriser vil der finde en ændring sted i fordelingen af det samfundsmæssige arbejde. Af hensyn til denne analyses formål må vi derfor undlade at tage hensyn til de kontinuerligt fluktuerende markedspriser og fokusere direkte på de regulerende priser.

30. F. Seton, »The 'Transformation Problem'«, Review of Economic Studies, 25. juni 1957 ss. $149-160$.

31. Se M. Morishima, Marx's Economics, Cambridge 1973, kap. 5-6, og A. Shaikh, Theories of Value and Theories of Distribution, Columbia University, Ph. D. Afhandling, 1973. I begge disse værker godtgøres det, at der er en ubrudt voksende forbindelse mellem pengeprofitraten r og den Marxske merværdirate m/c ved givne produktionsbetingelser. Selvfølgelig er også den Marxske profitrate $\mathrm{m} / \mathrm{c} \mathrm{v}$ en ubrudt voksende funktion af $\mathrm{m} / \mathrm{v}$ ved givne produktionsbetingelser. Således er pengeprofitraten en ubrudt voksende funktion af merværdiraten. 
I et givet år må summen af alle de producerede varers priser være lig med antallet af cirkularende mønter ganget med cirkulationshastigheden. Dette er, som Marx understreger, ganske simpel en tautologi. For at gøre det til noget mere, må vi indsætte det i en teoretisk sammenhæng.

Lad os begynde med at antage at de regulerende priser er direkte priser. Så svarer enhver vares pris til dens værdi i forhold til gulds, således at prissummen på alle producerede varer i et givet år er givet af deres totale værdi i forhold til guldets værdi. Lad TP betyde prissum, TW værdisum og Wg værdien af en enhed (en ounce) guld; vi kan så skrive

$$
\mathrm{TP}=\frac{\mathrm{TW}}{\mathrm{Wg}}
$$

I denne ligning er (regulerings) prisernes sum det direkte udtryk for varernes værdisum. Hvis cirkulationshastigheden er k, så er den mængde guld $\mathrm{G}$ (i form af et-ounce mønter), der er påkrævet som cirkulationsmiddel

$$
\mathrm{G}=\frac{\mathrm{TP}}{\mathrm{k}}=\frac{1}{\mathrm{k}} \frac{\mathrm{TW}}{\mathrm{Wg}}
$$

Årsagssammenhængen i dette er klar: værdisummen af de producerede varer i et givet år bestemmer summen af deres pengepriser, og dette bestemmer i forening med omløbshastigheden antallet af (etounce) guldmønter som behøves for at cirkulere varerne. ${ }^{32}$

Skønt de forangående relationer blev afledt på grundlag af direkte priser, bliver de ikke ændret det mindste når vi bevæger os videre til produktionspriser, idet de regulerende produktionspriser som Marx udleder har samme prissum som de direkte priser har. Dette betyder at for så vidt angår prissummen på alle varer er bestemmelsen den samme hvadenten vi forudsætter direkte priser eller produktionspriser: prissummen svarer til værdisummen divideret med en ounce guld. Alt $i$ alt er den nødvendige mængde guld den samme i begge tilfælde.

Hvad sker der så, når der er flere guldmønter end det nødvendige antal? Mængden $\mathrm{G}$ er det antal guldmønter som cirkulerer fordi de letter varernes cirkulation. Derfor vil enhver mængde mønter ud over denne mængde

32. K. Marx, Kapitalen, 1. bind op.cit. s. 231. 
være overflødig i cirkulationen: den vil straks tage form af ledige eller overskydende mønter. ${ }^{33}$

Imidlertid er et overskydende udbud af guld meget forskellig fra et overskydende udbud af enhver anden vare. For at kunne fuldføre deres funktion må alle andre varer blive solgt, de må forvandles til guld gennem handelens guldmageri; men guld behøver ikke - ja, kan i virkeligheden ikke - blive solgt. Det $e r$ penge ${ }^{34}$ den perfekte og varige rigdomsform som alle andre varer søger at opnå. Derfor har guld, som cirkulerer i form af mønter, fra vareproduktionens tidligste stade eksisteret side om side med ikke-cirkulerende guld som reservemønter, i form af skattesamlinger og luksusartikler.

Selve vareproduktionens natur, de uophørlige fluktuationer i priser og kvantiteter på markedet, nødvendiggør at enhver vareejer må ligge inde med en pengereserve for at kunne tilpasse sig dag-til-dag variationerne. Derfor vil det første bevis på et vedvarende overskud af mønter ud over det der behøves til cirkulationen være opbygningen af disse reserver ud over det nødvendige niveau; men så vil dette overflødige guld, som hverken er nødvendigt for den umiddelbare cirkulation eller for dens forventede variationer, blive trukket helt tilbage fra byttesfærens nærhed. Det vil enten blive til skattesamling eller blive omdannet til luksusartikler:

»Man har set hvordan der uophørligt er ebbe og flod i pengenes omløbsmængde på grund af vareomsætningens stadige svingninger i omfang, priser og hastighed. Omløbsmængden må altså kunne formindskes og udvides. Snart må penge tilføres som cirkulerende mønter, snart må de cirkulerende mønter trækkes ud af pengeomløbet. For at den faktisk cirkulerende pengemængde hele tiden kan svare til omsætningssfærens mætningsbehov, må den guld- og sølvmængde, der findes i et land, være større end den, der er optaget af at fungere som mønt. Denne betingelse opfyldes ved, at penge forefindes i form af skattesamlinger. ${ }^{35}$

I lande hvor vareproduktionen stadig er uudviklet, tager skattesamlinger form af privat akkumulation af guld spredt ud over landet. Men i takt med at vareproduktionen og hermed banksystemet udvikles og udvides, vil

33. K. Marx, Zur Kritik der politischen Ökonomie, MEW 13, Berlin 1969 kap. 2 afsnit 3a.

34. Selvfølgelig kan guldbarrer vise sig at blive solgt for en tilsvarende guldvægt i form af mønter; men dette er blot et formskifte fra umøntet til møntet guld. Det er ikke et salg eftersom der ikke er involveret nogen pris: En ounce guld er én ounce guld uden hensyn til dens skikkelse. Den samme konklusion kan man nå hvad angår det såkaldte guldsalg for guld-indløselige papirpenge. I dette tilfælde er papirpengene et tegn for en guldmængde der svarer til den mængde, som de køber. Marx diskuterer de illusioner, som pengetegn giver anledning til i Zur Kritik...

35. K. Marx, Kapitalen 1. bind, op.cit. s. 242 (oversættelsen rettet) 
skattesamlingerne blive samlet i bankerne. ${ }^{36}$ Under disse omstændigheder viser overskud eller mangel på guldpenge $\mathrm{i}$ forhold til cirkulationens behov sig som stigning eller fald i bankreserverne. ${ }^{37}$

Imidlertid er skattesamlinger i form af bankreserver meget forskellige fra private skattesamlinger: for bankerne er et overskud af bankreserver ud over det lovmæssigt krævede minimum en forsyning af ledig bankkapital, pengekapital som kunne tjene profit for banken i stedet for at ligge brak. En stigning i bankreserverne er derfor almindeligvis ledsaget af et fald i rentesatsen, idet bankerne bestræber sig på at ændre overskydende reserver til fungerende kapital. Et fald i bankreserverne til under det lovmæssige minimum vil omvendt tendentielt medføre en stigning i rentesatsen. Fremfor at hæve prisniveauet er den umiddelbare effekt af et overskud i guldmønter en sænkning af rentesatsen: hvis denne (kapital)eksport sker i form af ædelmetaller, vil det direkte påvirke penge-markedet og hermed rentesatsen...« $\ll^{38}$

Men nu kan man spørge: betyder den kendsgerning at bankerne sætter disse ekstra penge i cirkulation gennem en sænkning af rentesatsen ikke at den effektive efterspørgsel dermed bliver hævet? Og vil dette i så fald ikke igen betyde at priserne, som konsekvens af højere efterspørgsel, til syvende og sidst vil stige - således at kvantitetsteorien alligevel når alt kommer til alt er rigtig? Marx svar er et utvetydigt: Nej.

Vi begynder med at bemærke at et forøget guldudbud virkelig kan medføre en stigning i den effektive efterspørgsel, enten fordi det bruges igen af dets oprindelige ejere, eller indirekte fordi det udvider bankreserverne og hermed udbuddet af pengekapital der kan lånes, hvilket fremmer en sænkning af rentesatserne, og evt. forøger kapitalisternes lån til investeringer. ${ }^{39}$ Selvom denne stigning i den effektive efterspørgsel midlertidigt kan hæve priserne på nogle varer, og derfor hæve profitterne i nogle brancher, må det til sidst føre til en produktionsudvidelse til imødekommelse af den nye efterspørgsel. I og med at produktionen udvides vil priserne falde indtil de alt andet lige - vender tilbage til deres oprindelige niveau. I dette tilfælde

36. K. Marx, Zur Kritik... op.cit. s. 113 f.

37. Det er vigtigt at bemærke sig, at i Marx's analyse opstår skatteophobning af grunde der er specifikke for vareproduktion og/eller kapitalistisk vareproduktion. I Keynesianske analyser er skatteophobning i bund og grund baseret på psykologiske »tilbøjeligheder«.

38. K. Marx, Kapitalen, 3. bind op.cit.

39. Der er ikke nogen automatisk forbindelse mellem et fald i rentesatsen og en udvidelse af investerings-nniveauet. Investering afhænger ultimativt af muligheden for at skabe profitter; en lavere rentesats forøger investeringernes netto-profitabilitet, alt andet lige. Men dette medfører ikke i sig selv en automatisk investerings-udvidelse; ej heller medfører det nogen signifikant reaktion, også selv om andre faktorer ikke spiller ind. 
vil prissummen for alle varer være steget, ikke fordi prisniveauet er steget, men fordi den producerede varemængde selv er steget. Derfor: for så vidt en ren og skær stigning i guldudbuddet medfører en stigning i den effektive efterspørgsel (dvs. for så vidt den ikke blot udvider bankreserverne eller indgår i produktionen af luksusartikler), vil den også skabe et forøget behov for cirkulerende guldmønter.

Det er her vigtigt at bemærke, at for Marx er forestillingen om en kapitalisme som tenderer imod at have mere eller mindre »fuld beskæftigelse « et vulgært fantasifoster. Frem for alt slår Marx fast at kapitalismen har en indre tendens til at skabe og opretholde en relativ overskudsbefolkning af lønarbejdere - de ubeskæftigedes reservearme. ${ }^{40}$ For det andet kan der selv med en given fixkapital-sammensætning (bygninger og maskiner) let foretages en produktionsekspansion; det kræver blot en udvidelse og/eller intensivering af arbejdstiden. ${ }^{41}$ Endelig er det et iboende behov for den kapitalistiske vareproduktion, som kun reguleres gennem cirkulationsprocessen kontinuerlige fluktuationer, at opretholde lagre af forskellige varer således at cirkulationens krav kan imødekommes uden afbrydelse af kontinuiteten i produktionsprocessen. Det er lige netop på grund af disse forskellige slags reserver at produktionsprocessens kontinuitet er mulig side om side med konstant varierende niveauer i produktion og salg. ${ }^{42}$

»Det er yderst vigtig at begribe dette aspekt ved cirkulerende og fix kapital som sarlige former for kapital i almenhed, fordi temmelig mange fænomener i den borgerlige $\emptyset$ konomi - den $\emptyset$ konomiske cyklus periodicitet; (...) effekten af ny efterspørgsel; endog den effekt på den generelle produktion, som stammer fra nye guld- og sølvproducerende lande - ellers ville være ubegribeligt. Det er intetsigende at tale om den stimulus som skabes af australsk guld eller af lige opdagede markeder (...) hvis det ikke var indeholdt $i$ kapitalens natur aldrig at være fuldt udnyttet. (...) Bemærk samtidig hvilke meningsløse modsigelser som økonomerne strejfer om i selv Ricardo - når de forudsætter at kapital altid er fuldt udnyttet. (...) «33

Efter at have bestemt stedet for Marx's kritik af Ricardo's pengeteori, kan vi nu vende os til dens betydning for de guldstrømme der skabes af ændringer i den internationale handelsbalance. F.x. vil der i til fælde af handelsoverskud, være en netto-indstrømning af guld til landet og en heraf følgende stigning i landets guldbeholdning. For så vidt dette fører

40. K. Marx, Kapitalen, 3. bind kap. 25.

41. K. Marx, Kapitalen, 2. bind.

42. K. Marx, Grundrids, Århus 1978, s. 441-446.

43. Ibid. s. 477. (vores oversættelse fra den engelske udgave). 
til en stigning i den effektive efterspørgsel, vil produktionen udvides og med dette cirkulationens behov. En del af den forøgede guldforsyning vil derfor blive brugt til at imødekomme cirkulationens udvidede behov; en del opsamles i bankreserver, og en del vil blive opsuget i den udvidede produktion af luksusartikler lavet af guld. Når vi desuden tager hensyn til den internationale handel, kan en del af det overskydende guld blive reeksporteret i form af udenlandslån, som er på udkig efter renteindtægter, eller som udenlandsinvesteringer på jagt efter merværdi. Disse sidste to muligheder bliver, som vi kort skal se, vigtige i en marxistisk analyse af international handel.

I alle tilfælde forkaster Marx eftertrykkelig forestillingen om at en $»$ ren « forøgelse af udbuddet af guld i almindelighed vil føre til en stigning i priserne:

»Det er i virkeligheden den gamle flovse, at ændringerne i mængden af det forhåndenværende guld må hæve eller sænke varepriserne i landet, idet de forøger eller formindsker mængden af omløbsmidler i landet. Bliver der udført guld, så må varepriserne ifølge denne currency-teori stige i det land, hvortil guldet kommer, og dermed værdien af det guldudførende lands eksport på det guld-indførende lands marked; (...) Men i virkeligheden hæver formindskelsen af guldmængden kun rentefoden, mens forøgelsen af den sænker den; og hvis ikke disse svingninger i rentefoden blev regnet med i fastsættelsen af omkostningspriserne eller ved bestemmelse af efterspørgsel og udbud, så ville de lade varepriserne helt uberørte. « ${ }^{44}$

Det skal her bemærkes at Marx's pengeteori ikke blot implicerer en forkastelse af Hume's mønt-strøms mekanisme, hvorpå Ricardo's resultater var baseret, men også en forkastelse af de forskellige moderne versioner (nævnt i første del, afsnit 4) som har erstattet den.

Lad os begynde med en moderne version af kvantitets-teorien som er baseret på likviditets-balance opfattelsen. Det skal bringes i erindring af Hume's og Ricardo's klassiske kvantitets-teori angav, at udstrømningen af guld fra et land ville føre til et fald i pengeforsyningen og derfor i prisniveauet. I den moderne likviditets-balance version påstås det på den anden side at faldet i pengeforsyning betyder et fald i personers og firmaers likviditet; for »ikke at lade deres likviditet skrumpe for meget ind «, nedsætter folk i underskudslandet deres forbrugs- og investeringsudgifter; og dette fald i den samlede efterspørgsel fører igen til lavere priser og lønninger. ${ }^{45}$

44. K. Marx, Kapitalen, 3. bind kap. 34, s. 567.

45. L. B. Yeager, International Monetary Relations: Theory, History, and Policy, New York 1966, s. 64 . 
Den modsatte bevægelse finder sted i overskuds-landet, og til giver en absolut fordel plads for en komparativ fordel.

En alternativ vej til det samme resultat er at binde prisniveauet til pengelønsniveauet. Da konkurrencen fra billig klæde og vin fra udlandet betyder en reduktion i den indenlandske vin- og klædesproduktion, vil det opståede handelsunderskud i denne version blive forbundet med en stigning i arbejdsløsheden. Pengelønningerne i det tilbagestående land vil som følge heraf falde, og med den pengepriserne; i det førende land er handelsoverskuddet forbundet med udvidelse af beskæftigelsen, med en stigning i pengelønningerne, og derfor med en stigning i pengepriserne. Endnu en gang fører dette til den komparative fordels endelige herredømme. ${ }^{46}$ Det bør i denne forbindelse bemærkes, at selvom pengelønningerne var relativt ubevægelige nedad, kan resultatet ovenfor siges at holde, da alt hvad det behøver er en bevægelse $i$ et af de to prisniveauer for at kunne komme frem til de relative priser, som sikrer den komparative fordels herredømme.

Vi ser derfor at likviditets-balance opfattelsen hviler på at faldet i den effektive efterspørgsel i det tilbagestående land medfører et fald i pengepriserne. Men det er netop denne forbindelse mellem effektiv efterspørgsel og det permanente prisniveau, som Marx benægter. Da varernes prisniveau for Marx er bestemt af deres værdi i forhold til gulds, kan pengelønnen ligeledes ikke permanent påvirke prisniveauet: derfor vil den keynesianske pristeori heller ikke virke.

Indtil nu er hele diskussionen foregået på grundlag af guldstandarden, i hvilken det »sidste « grundlag for international valuta er en pengevare (som vi af bekvemmelighed kalder guld). I de fleste teoretiske diskussioner behandles guldstandarden som værende ensbetydende med faste kurser. Moderne afledninger af den komparative fordel gør derfor også krav på at være rigtig i tilfælde af faste kurser.

Det bringer os endnu en gang tilbage til muligheden for helt fleksible kurser som redskab til at fremkalde specialisering svarende til komparative omkostninger. Som bemærket i del I, afsnit 4, virker den faktiske guldstandard med en fleksibel kurs, der er bundet af grænser (guld-punkter), der er baseret på omkostningerne ved at transportere guld. Dette betød at det ved normale afvigelser var et system med flydende kurser, medens det i dets »afgrænsede « måde opererede som et system med faste kurser.

46. A. Amin, Accumulation on a World Scale: A Critique of the Theories of Underdevelopment, 2. bind, New York 1976 s. 47. Det bør bemærkes at Mandel er kritisk over for Amin fordi han accepterer denne vulgære teori (E. Mandel, Senkapitalismen, København 1977 s. 294 ff. 
Ud fra denne lange erfaring uddrog den ortodokse teori fejlagtigt begreberne om faste og flydende kurser som to polære ordninger. Helt flydende kurser præsenteres som en mekanisme hvormed et verdenskapitalistisk system i teorien kan være sammensat af helt »uafhængige « nationale valutaer. ${ }^{47}$ Som teoretisk mulighed har denne idé altid haft en usikker eksistens: valuta-»strømmenes « historie fremkalder meget stærkt en formodning om en blot begrænset fleksibilitet, ${ }^{48}$ og det internationale pengesystems historie er i høj grad en historie om tiltagende monetær integration, ikke adskillelse. I en vis forstand er forestillingen om helt flydende kurser der kun er bestemt af udbud og efterspørgsel, endnu et udtryk for den almindelige neoklassiske metode, i hvilken alle priser kun er bestemt af udbud og efterspørgsel. I modsætning hertil lægger Marx’s metode vægt på de væsentlige grænser for disse $\varnothing$ jensynlige variationer: med hensyn til priserne opstår disse grænser fra arbejdstiden; med hensyn til kurserne stammer disse fra eksistensen af pengevaren (i form af guldpunkter).

47. Yeager, op.cit. s. 104.

48. Ibid ss. 176-180. 


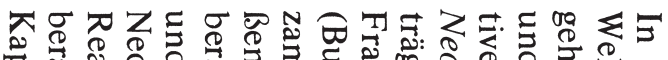

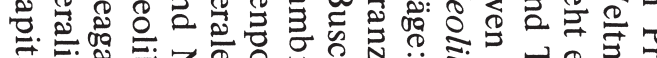

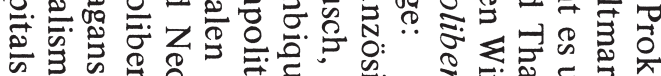

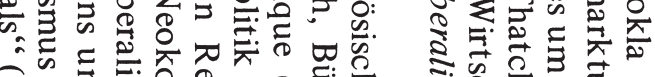

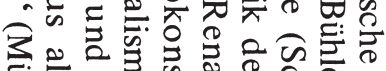

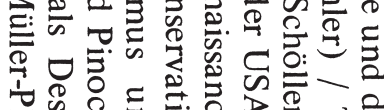

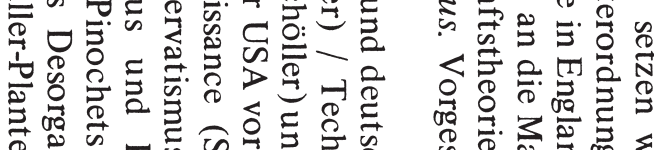

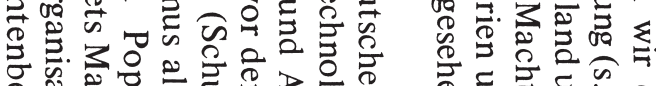

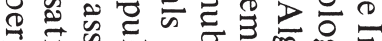

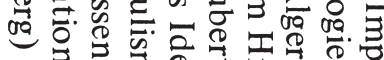

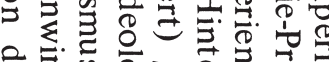

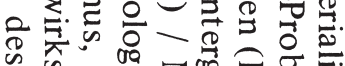

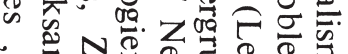

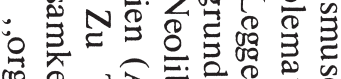

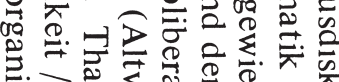

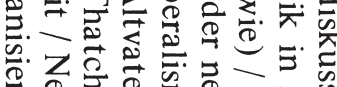

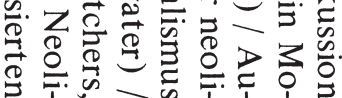

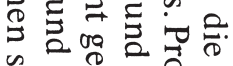

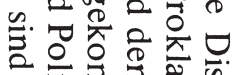

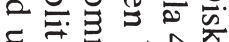

ค 즁

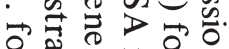

응

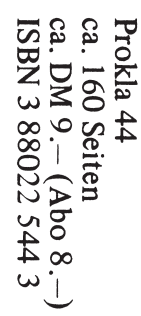

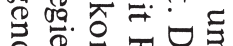

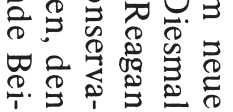

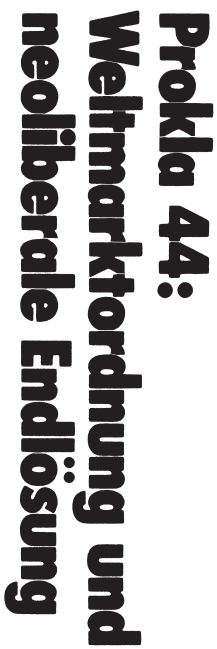

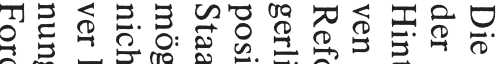

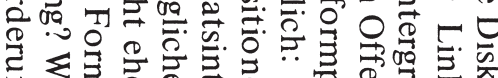

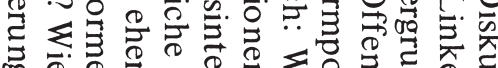

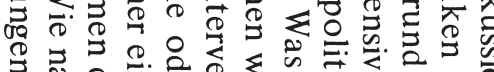

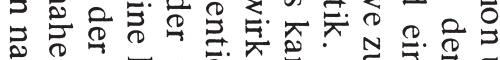

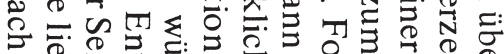
(T)

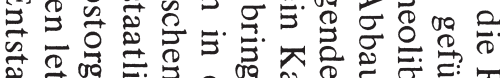

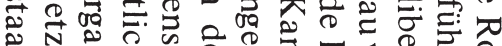

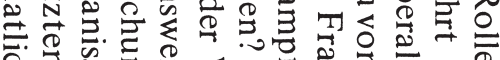

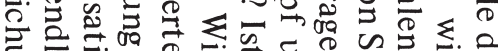

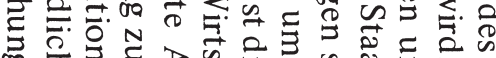
范 气

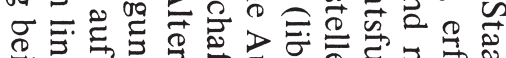
ब. 중

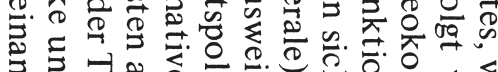

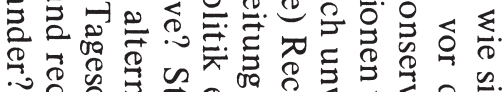

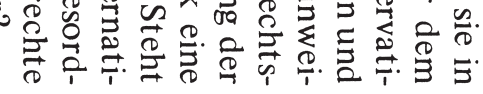

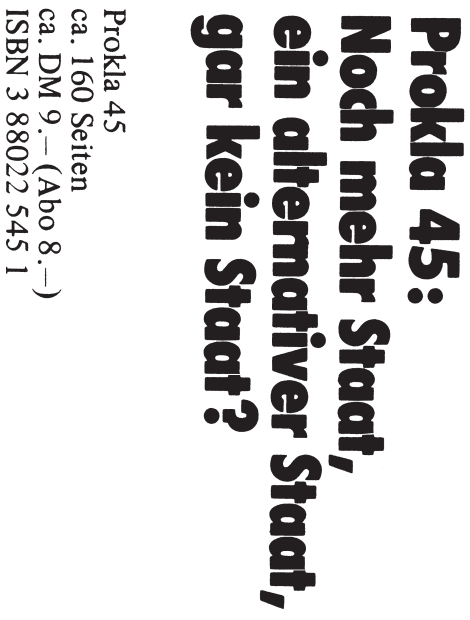




\section{Værdilov og verdensmarked.}

\section{En kritik af teorien om værdilovens modificerede funktion på ver- densmarkedet.*}

Tilla Siegel

Analysen af kapitalismen som et verdenssystem præger i stigende omfang den aktuelle samfundsvidenskabelige diskussion om internationale økonomiske problemer (imperialisme og afhængighed, multinationale koncerner $\mathrm{mm}$.), og fungerer dermed samtidig som en kritik af den tidligere dominerende behandling af disse problemer som »extern«- $\varnothing$ konomiske i forhold til nationen.

Med spørgsmålet om mekanismerne i den internationele værdidannelse giver teorien om værdilovens modificerede funktion på verdensmarkedet $^{1}$ et neomarxistisk bidrag til denne diskussion om det kapitalistiske

* Denne artikel er en omarbejdet udgave af et afsnit i bogen Tilla Siegel, Kapitalismus als Weltsystem. Methodische Probleme einer marxistischen Analyse des Weltmarktes.

Bogen er udkommet i januar 1980 på forlaget Campus i Frankfurt (Serien 'Campus Forschung').

Artiklen er oversat fra tidsskriftet »Mehrwert« nr. 21 af Finn Hansson.

1. Som fortalere for denne teori behandles:

Gunther Kohlmey, »Karl Marx' Theorie von internationalen Werten, Bd. 4, Berlin (DDR) 1961, s. 18 ff.,

Christel Neusüss, Imperialismus und Weltmarktbewegungen des Kapitals, Erlangen 1972, da. udg. Imperialismen og det kapitalistiske verdensmarked, København Kurasje 1976,

Klaus Busch, Die multinationalen Konzerne. Zur Analyse der Weltmarktbewegungen des Kapitals, Frankfurt 1974, da. udg. Imperialismen og de multinationale koncerner, Århus Pax Modtryk 1976,

Wolfgang Schoeller, Weltmarks und Reproduktion des Kapitals, Frankfurt 1976. 
verdenssystem. Af den omstændighed, at den nationalstatslige organisering af kapitaler indebærer, at verdensmarkedet er opdelt i nationale valutaer, udleder teorien en dybtgående modificering af den af Marx udviklede værdilov for så vidt angår verdensmarkedet. Denne modificering består i, at kapitaler i en nation med et overgennemsnitligt produktivitetsniveau kun i meget begrænset omfang, om overhovedet, kan gøre sine konkurrencefordele gældende.

Den følgende kritik skal vise, at ingen af de påståede modificerende gennemsættelser af værdiloven på verdensmarkedet kan afledes på værdilovens analytiske niveau og alene af, at verdensmarkedet er opdelt i nationale valutaområder, og at omtalte teori altså er forkert i sin logiske kerne. Kritikken sætter ind mod de fire punkter, der udgør det centrale grundlag for denne teori:

a) Det nationale markeds »normalitet « i modsætning til verdensmarkedet.

b) Den metodiske status af en undersøgelse af værdidannelsen på verdensmarkedet.

c) Adskillelsen mellem arbejdets produktivitet og intensitet.

d) Teoriens kernemodifikation af værdiloven på verdensmarkedet på baggrund af eksistensen af forskellige nationale valutaer.

\section{a) Det nationale markeds $»$ normalitet $«$ i modsætning til verdensmar- kedet.}

Logikken i den Marx'ske teori modsvarer den tankegang, at kapitalismen skal begribes som et verdenssystem og ikke som et nationalt begrænset system. Tilhængerne af den her behandlede teori går af denne grund og med rette ud fra Marx' udsagn om, at verdensmarkedet »overhovedet udgør kapitalismens basis og livsatmosfære «. ${ }^{2}$ Men allerede i deres bestemmelse af den samfundsmæssige enhed til hvilke de af Marx udviklede love for fordeling af det samfundsmæssige arbejde under kapitalismen ${ }^{3}$ henføres, fjerner de sig fra dette udgangspunkt, idet den samfundsmæssige enhed hos dem er nationen og ikke verdensmarkedet. Klaus Busch skriver eksempelvis mht. udledningen af værdiloven: »Forudsætningen for udfoldelsen af værdilovens virkning på verdensmarkedet er udviklingen af værdilovens mekanismer inden for nationale rammer «. ${ }^{4}$ Og overskriften i

2. Karl Marx, Das Kapital bd. 3, MEW 25, Berlin (DDR) 1969, s. 120, da. udg. København 1972, bd. 3.1, s.142.

3. Værdiloven og loven om dannelsen af produktionsprisen.

4. Klaus Busch, op. cit. s.13, da. udg. s. 12. (kursivering af T.S.) 
kapitlet hvor han beskriver værdiloven lyder: »Værdiloven inden for nationale rammer «.

Dertil kommer, at behandlingen af kapitalens verdensmarkedsbevægelse på værdilovens analytiske niveau bliver begrundet med, at med hensyn til dannelsen af produktionspris må der tages udgangspunkt i det indre markeds »normalitet «, eftersom dannelsen af produktionsprisen udelukkende finder sted på det indre marked og det kun er markedsværdien, der dannes på verdensmarkedet. Det næste afsnit vil udførligt behandle denne begrundelse, men først skal følgende grundlæggende forhold slås fast:

Marx måtte for overhovedet at kunne udvikle værdiloven og loven om dannelsen af produktionsprisen gå ud fra en logisk konstruktion i form af antagelsen om en ensartet kapitalisme, dvs. en kapitalisme med fælles politisk overbygning. Når han alligevel visse steder (især i behandlingen af produktionsprisen) henviser til nationale rammer, så skal det i forhold til logikken i hans teori kun forstås som illustrationer og ikke som en definition af nationen som en bestemmende eller »normal « samfundsmæssig enhed for disse loves virkning. Værdiloven og loven om dannelse af produktionsprisen er love, som regulerer fordelingen af det samfundsmæssige arbejde i den totale kapitalisme og denne kapitalismes virkelige udmøntning er verdensmarkedet. Så snart en kapitalistisk nation befinder sig i et - regelmæssigt - bytteforhold med andre lande (og det var siden den kapitalistiske produktionsmådes opståen tilfældet), kan der ikke længere forudsættes rene nationale værdi- og produktionsprisdannelser. Dette kan heller ikke forudsættes for varer som ikke eksporteres eller ikke konkurrerer med importvarer. For det første indgår importvarer (omend ikke alle) i produktionen af andre varer og for det andet er det samfundsmæssige behov ikke længere kun nationalt bestemt. I samme øjeblik man kan tale om et verdensmarked, og det kan man når den internationale handel ikke længere beror på tilfældigheder - så findes der ikke længere nationale værdier og produktionspriser men kun internationale.

Teorien om værdilovens modificerede funktion på verdensmarkedet beror på følgende inkonsistens: Teorien tager godt nok udgangspunkt i postulatet om verdensmarkedet som bestemmende enhed for analysen, men i antagelsen om at de nationale rammer er den »normale « enhed for værdiog produktionsprisbestemmelsen går det første postulat tabt.

Hvad angår gennemsættelsen af værdiloven og produktionsprisdannelsen er det indre marked for så vidt mere »normalt « end verdensmarkedet $^{5} \mathrm{i}$ den forstand, at den virkelige udligning af forskelle i individuel

5. »Normal« i den forstand, at det modsvarer den kapitalistiske produktionsmådes karakter. 
produktivitet og arbejdsintensitet foregår hurtigere pga. mindre friktion i konkurrencen. Det indre marked er også mere »normalt « $i$ den forstand, at de samme forhold bidrager til at tendensen til dannelse af en gennemsnitlig profitrate hurtigere sætter sig igennem inden for en national ramme. Men det indre marked er ikke mere »normalt « på den måde at det ikke i bund og grund er de samme lovmæssigheder i fordelingen af det samfundsmæssige arbejde, der gør sig gældende på verdensmarkedet som på det indre marked. ${ }^{6}$ Og det er heller ikke mere normalt på den måde, at værdidannelsen først fuldbyrdes i nationalt regi hvorefter den internationale værdi dernæst dannes af nationale værdier. ${ }^{7}$ Og endelig er det ikke mere normalt i den betydning »at varerne på verdensmarkedet står overfor hinanden som varebesiddernes varer og ikke uformidlet som produkter af kapital $\ll^{8}$, hvorfor profitraten på verdensmarkedet altså ikke spiller nogen rolle i prisdannelsen.

For at gentage: Verdensmarkedet er ikke noget som eksisterer udenfor nationen, men nationerne er verdensmarkedet. Den samfundsmæssige enhed som værdiloven virker indenfor er kapitalismen, som i sin virkelige skikkelse omfatter det samlede kapitalistiske verdenssystem. Hvis der altså kan tales om modifikationer i værdiloven på verdensmarkedet, da gælder det i lige så høj grad indenfor nationen.

Bag terminologien »modifikation af værdiloven « gemmer sig to forhold:

For det første siges det, at den proces, der realt reducerer den individuelle arbejdstid til den samfundsmæssigt nødvendige omfang er $\varnothing$ delagt, hvilket betyder, at den mere produktive vareproducent ikke kan udnytte sine konkurrencefordele overfor de mindre produktive producenter. Det er denne modifikation som den her kritiserede teoris $\emptyset$ ger at eftervise for verdensmarkedet.

For det andet siges det, at fordelingen af det samfundsmæssige arbejde ikke alene sker over denne reduktion, men også gennem andre processer. Loven om dannelsen af produktionspriser omfatter denne anden type modifikation, idet den beskriver den indflydelse, som dannelsen af den gen-

6. F.eks. det forhold på verdensmarkedet, at den mere produktive producent ikke samtidig kan være den mest billige.

7. En sådan slutning forledes de her nævnte forfattere til af Marx' udsagn om, at de »nationale gennemsnit (af produktivitet og arbejdsintensitet, T.S.) .. (udgør) en skala, hvis måleenhed er det universelle arbejdes gennemsnitsenhed.« Marx, Das Kapital bd. 1, MEW 23, s. 584, da.udg. bd. 1.3, s. 788 .

8. Christel Neusüss, op.cit., s. 100, da.udg. s. 96. 
nemsnitlige profitrate har på fordelingen af det samfundsmæssige arbejde under kapitalismen. ${ }^{9}$

Analog til den her diskuterede teori undersøges i denne artikel kun om det på værdilovens niveau er muligt at aflede den første form for modifikation ud fra kapitalismens underopdeling i nationale valutasfærer.

\section{b) Den metodiske status af en undersøgelse af værdidannelsen på verdensmarkedet.}

Den af Marx formulerede værdilov omhandler grundprincipperne for fordeling af det samfundsmæssige arbejde i et vareproducerende samfund. Den er kun det første analytiske skridt i undersøgelsen af mekanismerne bag fordelingen af det samfundsmæssige arbejde i et kapitalistisk vareproducerende samfund, eftersom den ikke indeholder profitraternes udligning. I værdidannelsen kommer det til udtryk om det forbrugte individuelle arbejde er samfundsmæssigt nødvendigt arbejde - nødvendigt såvel mht. produktivitetens gennemsnitlige niveau som mht. det (betalingsdygtige) samfundsmæssige behov. Markedets sammenligningsprocesser virker først som en ideel reduktion af det individuelle arbejde til dets samfundsmæssigt nødvendige omfang. Men pga. dette bliver producenterne også på længere sigt tvunget til at tilpasse deres forbrug til den samfundsmæssige reproduktions krav, hvorfor der er også heraf følger en virkelig udligning. Den virkelige udligningsproces kan imidlertid først for alvor tillægges det kapitalistiske vareproducerende samfund, eftersom dette samfunds bestemmende princip - kapitalvaloriseringen - fremskynder eller rettere fremtvinger denne virkelige udligningsproces.

Den her behandlede teori går ud fra en real markedsværdidannelse på verdensmarkedet. Før vi fremstiller begrundelsen herfor og kritiserer denne teori, kommer her et indskud om begrebet »markedsværdi «:

Adskillelsen mellem individuel værdi og markedsværdi, som Marx udfører i Kapitalens 3. bind, er en hjælpekonstruktion, der i sig selv arbejder med falske begreber. Der findes ingen individuel værdi men kun individuelt forbrugt arbejdstid. Værdi er altid en samfundsmæssig kategori. Markedsværdi er en plenoplasme, idet spørgsmålet om overhovedet og i hvilke udstrækning arbejde er samfundsmæssigt, dvs. værdidannende,

9. Med sin teori om ulige bytte på det kapitalistiske verdensmarked afleder A. Emmanuel på dette niveau en modifikation i forhold til en logisk konstrueret kapitalisme med ens overbygning, idet han fastslår, at de antagelser om ens merværdirate som ligger til grund for Marx' fremstilling af produktionsprisdannelsen ikke gælder for verdensmarkedet. Arghiri Emmanuel, L'echange inegal, Paris 1969. 
altid først besvares på markedet. Marx har anvendt denne terminologiske adskillelse for endnu engang at henvise til den betydning, som det samfundsmæssige behov har for værdidannelsen. Eksempelvis bortødsler en producent ikke blot samfundsmæssigt arbejde, når han fremstiller sin vare med undergennemsnitlig produktivitet, men også, når der ikke eksisterer et samfundsmæssigt behov (udtrykt i betalingsdygtig efterspørgsel) for varen. Det er kun på baggrund af henvisningen til dette »kvalitative « aspekt ved værdidannelsen, at Marx kan forklare de kapitalbevægelser, som fører til en gennemsnitsprofitrate og dermed til dannelsen af produktionspriser.

I sig selv er undersøgelsen af mekanismerne bag fordelingen af det samfundsmæssige arbejde i kapitalismen ufuldstændig på værdilovens niveau, eftersom denne stadig udelukker profitratedannelsens indflydelse. Selv i de tilfælde, hvor en gennemsnitsprofitrate ikke har sat sig igennem drejer det sig under kapitalistiske produktionsbetingelser primært om realisering af profit og ikke om realisering af værdi slet og ret. Profitdannelsen virker også ved en gennemsnitsprofitrates fravær ind på prisdannelsen, dvs. forudsat kapitalistisk vareproduktion, så svinger prisen i sådanne tilfælde ikke omkring værdien og prisen i stemmer kun helt tilfældigt overens med værdien. ${ }^{10}$

Når der her argumenteres på værdidannelsens niveau, skal det forstås som et logisk skridt i unders $\varnothing$ gelsen af den samfundsmæssige arbejdsdeling, som ikke alene kan forklare dennes form. I denne forstand er følgende udsagn af Marx også forkert eller i det mindste vildledende:

»Bortset fra, at priser og prisbevægelser beherskes af værdiloven, er det helt igennem korrekt at opfatte varernes værdier som noget der ikke blot teoretisk, men også historisk går forud for produktionspriserne. $\ll^{11}$

Den reduktion af den individuelle arbejdstid til det samfundsmæssigt nødvendige omfang, som ligger tilgrund for markedsværdien fuldbyrdes kun i et udviklet vareproducerende samfund og sådanne samfund har hidtil kun vist sig i det kapitalistiske samfunds form. Og i disse har markedsværdien aldrig udviklet sig realt, dvs. som prisernes occilationscentrum, men det har derimod produktionsprisen. Problemet med at unders $\emptyset$ ge den »modifikation«, som værdiloven undergår på verdensmarkedet er, at man for at forklare sig ind imellem må gå ud fra hypotesen om et enkelt vare-

10. Jeg anvender af samme grund også begrebet produktionspris i de tilfælde, hvor der ikke eksisterer nogen gennemsnitsprofitrate, og definerer det: produktionspris $(\mathrm{pp})=$ kostpris + profit. (Til forskel fra Marx' definition: $\mathrm{pp}=$ kostpris + gennemsnitsprofit).

11. Understreget af T.S., Marx, Das Kapital bd. 3, s. 186, da. udg. 3.1, s. 229.

Frederich Engels fors $\emptyset$ ger at underbygge denne tese i sit efterord, Ibid., s. 905-6. 
producerende samfund og varebytte til værdier, på trods af, at et sådant samfund aldrig har eksisteret og på trods af, at det er højst tilfældigt om varerne byttes til deres værdi i den kapitalistiske $\varnothing$ konomis realitet. Selv om det helt igennem er en korrekt fremgangsmåde, så forleder den dog til antagelser om, værdien - i det mindste som tendens - som noget realt, som noget, der har status som oscilationscentrum for priserne, og værdidannelsen bliver dernæst betragtet som modificeret af faktorer, som må placeres på et meget konkret analyseniveau. Christel Neusüss og Klaus Busch begår denne fejl, idet de direkte forbinder værdidannelsens niveau med vekselkursmekanismernes i deres fremstillinger. Men værre endnu: de går ud fra en virkelig markedsværdidannelse i deres analyser af verdensmarkedet. ${ }^{12}$ De forveksler spørgsmålet om hvorvidt priserne i virkeligheden svinger omkring markedsværdien med spørgsmålet om, hvorvidt reduktionen af det individuelle arbejde til samfundsmæssigt nødvendigt arbejde i virkeligheden finder sted, om producenterne altså i virkeligheden er tvunget til en udligning af arbejdsproduktivitetens og arbejdsintensitetens niveau.

Christel Neusüss begrunder sin fremgangsmåde således:

»Da dannelsen af en gennemsnitlig profitrate virker som tendens, når varerne står overfor hinanden som produkter af kapital, har Marx altså i den manglende betydning af profitrateforskellene for de enkelte nationale kapitaler i den internationale handel forudsat, at varerne på verdensmarkedet i første omgang står overfor hinanden som varebesiddernes varer og ikke uformidlet som produkter af kapital. $\ll^{13}$

Og videre: »Det, som gælder for konkurrencens historiske gennemslagsproces og dens resultater, nemlig først frembringelse af samme markedsværdi og markedspris ud af de forskellige individuelle vareværdier inden for en produktionssfære, så frembringelse af produktionsprisen og dermed egalisering af profitterne mellem de forskellige sfærer, må også antages at gælde for verdensmarkedskonkurrencen under hensyntagen til de særlige momenter, som kommer oven i. De friktioner, som i første omgang modvirker kapitalens og arbejdskraftens bevægelighed mellem de forskellige produktionssfærer og som hindrer udligningen til en gennemsnitsprofitrate, bliver af Marx »inden for visse grænser« sammenlignet med friktionerne i konkurrencen mellem forskellige lande. (jvf. Das

12. Deres kritikere W. Bärtschi og H.D. Jacobson anvender »internationale værdier som oscillationscentrum for markedspriserne «. Internationaler Handel und internationale Ausbeutung, m.M. Berlin u.å. s. 45.

13. Christel Neusüss, op.cit. s. 100, ds. udg. s. 96-97. 
Kapital bd. 3, s. 190, da. udg. s. 233-34) Forskellen mellem konkurrencen inden for en national kapital og verdensmarkedskonkurrencen må således ses i sammenhæng med den forskel, som Marx anfører mellem forudsætningerne for udviklingen af samme markedsværdi og markedspris for en og samme vare på den ene side og forudsætningerne for dannelsen af en gennemsnitsprofitrate mellem produktiosnsfærerne på den anden side, og den må begribes som en forskel, der implicerer en tendens til sin egen udligning. $\ll^{14}$

Christel Neusüss bygger således entydigt sin argumentation på Marx' udsagn om, at markedsværdien ikke blot teoretisk men også historisk går forud for produktionspriserne. Hun begrunder sin analogi mellem den reale udvikling på verdensmarkedet og den logiske fremgangsmåde i Marx' fremstilling af produktionsprisen med, at der endnu ikke eksisterer en gennemsnitsprofitrate på verdensmarkedet og at vareproducenterne ikke optræder enkeltvis (som inden for nationen) men som nationale enheder. »I cirkulationens sammenstilling af varer sammenlignes varernes totalvardi, uanset hvorledes denne totalværdi - som må udgøres af samfundsmæssigt nødvendig arbejdstid - fordeler sig på sine forskellige bestanddele $(\mathrm{k}, \mathrm{v}$ og m eller ved produktionspriser: kostpris og gennemsnitsprofit). $\ll{ }^{15}$ Men også på verdensmarkedet bliver vare- og kapitalbevægelser gennemført af enkeltkapitaler, heller ikke her træder kapitalerne overfor hinanden en bloc. Og det forhold, at gennemsnitsprofitraten endnu ikke har gennemsat sig internationalt, berettiger ikke en antagelse om, at der internationalt eksisterer en tendens til at bytte til markedsværdien. Tilbage står, at varerne er kapitalistisk producerede, og at det for den sælgende kapitalist primœrt drejer om profitraten. Varer kan også på verdensmarkedet udmærket sælges under deres værdi, sålænge profitraten er tilstrækkelig stor. Omvendt kan kapitalisten miste interessen $i$ at producere en vare selvom den kan sælges til sin værdi, når denne pris betyder en for lav profitrate. Fraværet af en international gennemsnitsprofitrate betyder ikke real gennemsættelse af markedsværdien men ene og alene, at varens pris ikke svinger omkring kostpris og international gennemsnitsprofit, men omkring kostpris plus nationalt forskellig profit.

Som begrundelse for at forblive inden for markedsværdianalysen i forbindelse med unders $\emptyset$ gelsen af konkrete verdensmarkedsmekanismer anfører Klaus Busch, at internationale kapitalbevægelser især har fundet sted inden for produktionssfærer, mens de kapitalbevægelser mellem

14. ibid., s. 114, da. udg. s. 109-110.

15. ibid., s. 115, da.udg. s. 110 . 
forskellige produktionssfærer som Marx behandler i sin fremstilling af gennemsnitsprofitraten ikke eller næsten ikke har fundet sted internationalt. ${ }^{16}$

»Det skulle imidlertid være blevet tydeligt, at disse internationale kapitalbevægelser ikke fører til internationale produktionspriser og via denne formidlede værdi-form tendentielt producerer en international gennemsnitsprofitrate, thi den internationale kapitalvandring forløber gennem de her fremstillede mekanismer i første række inden for kapitalens enkelte investeringssfærer og bevirker derfor udelukkende ændringer i den internationale, branchespecifikke markedsværdikonstitueringsproces. ${ }^{17}$

Også her bliver modargumentet, at eftersom varen er produceret kapitalistisk er den faktor som i sidste instans er afgørende profitraten - uanset om den er nationalt eller internationalt bestemt - og ikke værdien selv. Begge forfattere burde på dette punkt have fulgt deres åndelige far G. Kohlmey, idet han ikke glemte, at også de varer som byttes internationalt er produceret kapitalistisk. G. Kohlmey kom til den slutning, at uanset nationale forskelle i profitraten så svinger verdensmarkedsprisen mellem de nationale produktionspriser. ${ }^{18}$

Hvad angår undersøgelsen af verdensmarkedet kan det ikke handle om spørgsmålet om hvorvidt verdensmarkedsprisen realt svinger omkring verdensmarkedsværdien, idet dette spørgsmål er blevet afvist med påvisningen af, at varerne er kapitalistisk producerede. Det kan derimod handle om, hvorvidt den nationalstatslige organisering af kapitalen $\varnothing$ delægger den virkelige reduktion af det individuelle arbejde til samfundsmæssigt nødvendigt arbejde på verdensmarkedet, om altså tvangen til en udligning af produktivitets- og arbejdsintensitetsniveauerne også er $\varnothing$ delagt her.

\section{c) Forskellen mellem produktivitet og arbejdsintensitet.}

Vi tager her udgangspunkt i Marx' begreb om produktivitet: Produktivitet er bestemt af forholdet mellem den samlede mængde arbejde, som sættes i bevægelse (levende og genstandsgjort) $o g$ den mængde brugsværdier der produceres. Dette produktivitetsbegreb er bedre egnet til vores problemstilling end det begreb, der hyppigst anvendes idag, hvor forholdet mellem produktionsomkostninger og produktionsoutput måles i priser. Det

16. Klaus Busch, op.cit. s. 46 ff, da.udg. s. 1148-49.

17. ibid., s. 52, da. udg. s. 41. Jvf. også s. 42, da. udg. s. 34 .

18. G. Kohlmey, op.cit. s. 59. 
førstnævnte begreb omfatter entydigt produktionens tekniske niveau, mens det sidstnævnte påvirkes af faktorer som lønhøjde, profitrate osv.. Det er udelukkende med udgangspunkt i det her valgte produktivitetsbegreb, at man overhovedet kan rejse spørgsmålet om, hvilke faktorer i international sammenhæng, som kan udvirke en forvandling af et absolut produktivitetsefterslæb til en relativ prisfordel.

Det skal understreges, at den her anvendte definition ikke muliggør en direkte sammenligning af produktiviteten mellem forskellige produktionssfærer. Eksempelvis kan man herudfra ikke sige, at stålindustrien er mere produktiv end tekstilindustrien eftersom man ikke kan sammenligne stål og tøj som brugsværdier. Men man kan sige, at målt efter det produktivitetsniveau, som internationalt har gjort sig gældende som det højest mulige, så er stålindustrien i et land mere produktiv end tekstilindustrien i det samme land - forstået på den måde, at stålindustrien befinder sig nærmere sin internationalt gyldige produktivitetsgrænse end tekstilindustrien i forhold til sin. Gradsforskellen i afstanden mellem industriens produktivitet $\mathrm{i}$ et land i forhold til andre lande spiller en rolle for det her rejste spørgsmål om hvorfor samme industrigren i et land kan være samme industrigren fra et andet land underlegen i den internationale konkurrence, selvom sidstnævnte relativt producerer uproduktivt.

Hvad angår bestemmelsen af det »universelle arbejde«, dvs. det arbejde, der er samfundsmæssigt nødvendigt på det kapitalistiske verdensmarked, er der af Marx og hans efterfølgere G. Kohlmey, Christel Neusüss, Klaus Busch og Wolfgang Schoeller fastslået nogle særtræk, som ikke i mine øjne er særtræk.

Det begynder med at Marx gør en forskel mellem et produktivitetsforspring og et forspring $\mathrm{i}$ arbejdsintensitet $\mathrm{i}$ sin diskussion af producenter som anvender mindre end den gennemsnitlige samfundsmæssige nødvendige arbejdstid i produktionen af deres varer. Marx skriver:

»Voksende arbejdsintensitet forudsætter, at der ydes mere arbejde $\mathrm{i}$ løbet af samme tid. Den arbejdsdag, der er mere intensiv, legemliggøres derfor i flere produkter end en arbejdsdag med samme timetal, men som er mindre intensiv. Med forhøjet produktivkraft giver den samme arbejdsdag ganske vist også flere produkter. Men i det sidste tilfælde falder det enkelte produkts værdi, eftersom det koster mindre arbejde end før, mens det i det første forbliver uændret, da produktet koster lige så meget arbejde som før. Her vokser antallet af produkter, uden at prisen på dem falder. Med antallet af produkter vokser summen af deres priser, mens ved forhøjet produktivkraft den samme værdisum blot blev udtrykt i en forøget mængde produkter. Den mere intensive arbejdsdag kommer altså ved uforandret 
timetal til udtryk i et større værdiprodukt, dvs. i flere penge, hvis der ikke sker ændring i pengenes værdi. « ${ }^{19}$

Marx har trukket denne forskel frem i sammenhæng med analysen af merværdiraten..$^{20} \mathrm{I}$ denne sammenhæng virker den rimelig for så vidt, at en stigning i arbejdsintensiteten bevirker en direkte stigning i merværdiraten på produktionsstedet, mens en forøgelse af produktiviteten kun påvirker merværdiraten, når det resulterer i en billiggørelse af varer, som indgår i reproduktionen af arbejdskraft og derigennem sænker dennes værdi. ${ }^{21}$ Denne forskel er også betydningsfuld for arbejderen, da en arbejdsintensivering betyder et forøget forbrug af arbejdskraft, mens dette ikke er tilfældet med en forøgelse af produktiviteten (sålænge denne ikke er forbundet med forøget intensitet).

Set i forhold til værdibestemmelsen kan der ikke fastholdes nogen forskel. Ligemeget om en vare kan fremstilles på kortere tid end hvad der er samfundsmæssigt nødvendigt pga. st $\varnothing$ rre arbejdsintensitet med uændret tekniske betingelser eller pga. bedre tekniske betingelser, så vil den i varen legemliggjorte arbejdstid i begge tilfælde blive reduceret hhv. potenseret til gennemsnitlig samfundsmæssig nødvendig arbejdstid gennem (markeds-)værdidannelsesprocessen. Og i det tilfælde, hvor de andre producenters produktivitetsniveau udlignes til det niveau, som en tidligere overgennemsnitlig producent havde, gælder det samme som for udligning af intensitet:

»Hvis arbejdsintensiteten tiltog $\mathrm{i}$ alle industrigrene på samme tid og i samme grad, ville den nye og højere grad af intensitet blive til den sædvanemæssige normalgrad i samfundet og ophøre dermed at gælde som ekstensiv størrelse. $\ll^{22}$

Marx går et skridt videre og skriver, at produktivitets- og arbejdsintensitetsforskelle på verdensmarkedet indgår på en anden måde i værdibestemmelsen end det er tilfældet inden for en nation:

$\gg$ I hvert enkelt land gælder der en vis middelintensitet for arbejdet. Ligger arbejdet ved at fremstille en vare herunder, forbruges der mere tid end samfundsmæssigt nødvendigt, og arbejdet bliver i så fald ikke regnet som arbejde af normal kvalitet. Det er kun en intensitetsgrad, der ligger over

19. Das Kapital bd. 1, s. 547, da.udg. 1.3, s. 742. Jvf. også s. 548, da.udg. s. 743 og det meget citerede sted fra s. 583/84, da. udg. s. 788, som er anført i note 23.

20. Dette fremgår allerede af overskrifterne fra de afsnit og kapitler, som disse citater stammer fra: »Femte afsnit: Produktion af den absolutte og relative merværdi « og »Kapitel 15: Ændringer i størrelsen af priser på arbejdskraft og merværdi«, ibid.

21. Ibid. s. 547 ff, da.udg. bd. 1.3 s. 742 ff.

22. Ibid. s. 548 , da.udg. 1.3 s. 743 . 
det nationale gennemsnit, som ændrer værdimålet $\mathrm{i}$ et givet land gennem arbejdstidens blotte varighed. Anderledes forholder der det sig på verdensmarkedet, som de enkelte lande er integrerende dele af. Arbejdets middelintensitet varierer fra land til land. Det ene sted er den større, det andet mindre. Disse nationale gennemsnit udgør således en skala, hvis måleenhed er det universelle arbejdes gennemsnitsenhed. Sammenlignet med det mindre intensive arbejde, producerer følgelig det mere intensive nationale arbejde mere værdi i løbet af den samme tid, hvilket kommer til udtryk i flere penge.

Værdiloven bliver imidlertid modificeret endnu mere, når den anvendes internationalt, ved det forhold, at på verdensmarkedet gælder det mere produktive nationale arbejde ligeledes som det mere intensive i alle de tilfælde, hvor den mere produktive nation ikke bliver tvunget gennem konkurrencen til at sænke salgsprisen på sine varer til varernes værdi. $\ll^{23}$

Kohlmey, Neusüss og Busch behandler alle indgående denne differentiering, som der ikke kan hentes belæg for ud fra Marx' analyse af markedsværdien ${ }^{25}$ og behandling af ekstramerværdien ${ }^{26}$. Den arbejdstid, som bestemmer vareværdien er altid et vejet gennemsnit af de forskellige individuelle arbejdstider, som de enkelte producenter har anvendt (forudsat et tilstrækkeligt samfundsmæssigt behov). »Hvor arbejdets produktivkraft (og/eller undtagelsesvis intensitetsgrad, T.S.) er usædvanlig høj virker det som potenseret arbejde eller skaber i det samme tidsrum højere værdier end samfundsmæssigt gennemsnitsarbejde af samme art « ${ }^{27}$.

Kohlmey slår yderligere et særtræk fast ved det internationale bytte mellem nationer med forskellig produktivitet: »Den internationale handel er udveksling af nationalt arbejde, af nødvendigt arbejde og af merarbejde. Den internationale handel er, forudsat udveksling til internationale værdi-

23. Ibid. s. 583-4, da.udg. 1.3 s. 788. Den nedenfor citerede fortsættelse af denne tekst fra Kapitalens 1. bind har forledt de her kritiserede forfattere til en forkert bestemmelse af den nationale valutas værdi, jvf. afsnit d) i denne artikel. »I samme udstrækning som den kapitalistiske produktion er udviklet i et land, hæver arbejdets intensitet og produktivitet i landet sig også over det internationale niveau. De forskellige mængder af varer af samme art, der i forskellige lande produceres i løbet af den samme arbejdstid, har altså forskellig international værdi, hvad der kommer til udtryk i forskellige priser dvs. i pengesummer, der varierer med de internationale værdier. Pengenes relative værdi vil altså være mindre hos den nation, der har en mere udviklet kapitalistisk produktionsmåde end hos den nation, hvor den er mindre udviklet.«

24. Jvf. G. Kohlmey, op.cit, s. 43-44, K. Busch, op.cit., s. 34 ff, da.udg. s. 28, C. Neususs, op.cit., s. $94 \mathrm{ff}$, især s. $115 \mathrm{f}$, da.udg. s. 89 og 110

25. Jvf. Das Kapital bd. 3, 10. Kapitel, især s. 187-88 og s. 192 ff., da. udg. bd. 3.1 s. 230-31 og s. 236.

26. Jvf. Das Kapital bd. 1, s. 336-337, da.udg. 1.2 s. 476-77.

27. Ibid s. 337, s. 477. 
er, en omfordeling af det nationalt forbrugte arbejde, af arbejdsresultaterne fra det mindre produktive land til det mere produktive. Dette er hovedtesen i den Marx'ske teori om internationale værdier. Der opstår en væsentlig modifikation af det almene værdiproblem, men der er ikke tale om et kvalitativt nyt problem. $\ll^{28}$

Men også i den indenlandske handel opnår den producent, som producerer under bedre betingelser end gennemsnitligt, mere legemeliggjort samfundsmæssigt nødvendigt arbejde i en anden vare i bytte for den legemeliggjorte arbejdstid i sin egen vare, idet hans arbejde »virker som potenseret arbejde.«Også her ser vi et ulige bytte af arbejdsmængder.

Modsat Kohlmey, Neusüss, Busch og Marx hælder jeg til den opfattelse, at værdibestemmelsen på verdensmarkedet må følge samme principper som på et nationalt marked. Det gælder i lige så høj grad for verdensmarkedet som for det nationale marked, at så længe den mere produktive nation (den mere produktive producent) »ikke bliver tvunget gennem konkurrencen til at sænke salgsprisen på sine varer til varernes værdi ${ }^{29} \ll^{30}$, så producerer de i samme tid mere værdi, udtrykt i penge, end de mindre produktive nationer (producenter).

Forskellen mellem verdensmarkedet og de nationale markeder består i, at opdelingen af verdensmarkedet i nationalstater hindrer den fulde virkning af den konkurrence, som sikrer, at den overgennemsnitligt produktive producent må sænke sine priser i overensstemmelse hermed og den mindre produktive bliver tvunget til at forøge sin produktivitet eller forsvinde fra markedet (opgive produktionen).

Der er altså tale om, at den virkelige proces som udligner arbejdsproduktiviteten og - intensiteten sætter sig langsommere igennem på verdensmarkedet end inden for nationen. Kun på denne måde bør Marx' - misvisende - udsagn i kap. 20 i Kapitalens 1 . bind forstås ${ }^{31}$.

Trods dette bringer diskussionen af arbejdsproduktivitet og -intensitet ingen antydning af svar på spørgsmålet om, hvilke faktorer på verdensmarkedet, der bevirker, at den relativt mindre produktive producent meget længe kan eksistere side om side med sine mere produktive konkurrenter

28. Kohlmey, op.cit. s. 47.

29. Det ville være bedre at sige »sine individuelle, nationale arbejdsomkostninger.«

30. Das Kapital bd. 1, s. 584, da.udg. 1.3 s. 788.

31. I forlængelse af min fremstilling af værdiloven kan man tale om forskellige nationale niveauer mht. produktivitets - og arbejdsintensitet men pga. verdensmarkedets eksistens ikke om nationale værdier. Værdibestemmelsen sker på basis af det samlede kapitalistiske samfund og det er verdensmarkedet og ikke den enkelte nation. 
fra andre lande og hvilken indflydelse dette har på den internationale arbejdsdeling. ${ }^{32}$

Det er først i næste trin af deres analyse, at C. Neusüss og K. Busch, som her tages som repræsentanter for denne skole, udvikler en ansats til løsning af dette problem, en løsning som på samme tid er enkel, forbløffende men også forkert.

\section{d) Værdilovens modifikation på verdensmarkedet gennem eksisten- sen af forskellige nationale valutaer - teoriens kerne.}

Med udgangspunkt i det forhold, at varen på verdensmarkedet ikke direkte kan sammenlignes via en international pengeenhed, men at denne sammenligning formidles over nationale valutaer, kommer disse forfattere til det resultat, at »... de $\varnothing$ konomisk svagere udviklede nationer bliver beskyttet mod de højst udviklede nationers $\varnothing$ delæggende konkurrencekraft. « ${ }^{33}$

Jeg skal ikke her opholde mig ved den udtalt problematiske bestemmelse af vekselkursmekanismerne hos Neusüss og Busch og heller ikke ved deres utilladelige direkte slutning fra værdilovens abstrakte niveau til valutamekanismernes konkrete. For mig drejer det sig om kernen i deres teori: at på værdilovens abstrakte niveau forsøge at vise, at alene på grund af det forhold, at der eksisterer en opdeling af verdensmarkedet i valutaområder, finder der en væsentlig modifikation af den internationale arbejdsdelingsproces sted. Klaus Busch' fremstilling viser fremgangsmåden i deres argumentation:

»Arbejdsværdigrundlaget for disse internationale penge- og prisbevægelser lader sig illustrere med følgende eksempel:

På verdensmarkedet står tre nationer $\mathrm{A}, \mathrm{B}$ og $\mathrm{C}$ over for hinanden; de råder over forskellige niveauer i produktivkraftudviklingen. A er den højst udviklede nation, den realiserer altså den højeste gennemsnitlige grad af arbejdsintensitet og dens produktionsgrene producerer sammenlignet internationalt med den højeste grad af arbejdsproduktivitet. B er den gennemsnitligt og $\mathrm{C}$ den svagest udviklede nation. Da $\mathrm{A}$ råder over det højeste niveau af arbejdsintensitet og arbejdsproduktivitet, kommer en national arbejdsdag i A til udtryk i større internationale værdier end en tilsvarende arbejdsdag i B og C. Hvis vi kalder de internationale værdiers værdisubstans »universelt arbejde«, så repræsenterer måske 1 national arbejdsdag i A 2 universelle arbejdsdage, 1 national arbejdsdag i B 1 universel arbejdsdag

32. Som en selvfølge går jeg alle steder ud fra frihandel.

33. Busch, op.cit. s. 42, da.udg. s. 34-35. 
og 1 national arbejdsdag i C en halv universel arbejdsdag. Hvis vi nu også indfører den almene ækvivalent i dens nationale og dens internationale form, så kan vi opstille følgende ligninger:

$1 \mathrm{n} A D$ i $\mathrm{A}=1 \mathrm{nVE}$ i $\mathrm{A}=2 \mathrm{u} A D=2 \mathrm{iVE}$

$1 \mathrm{n} A D$ i $B=1 \mathrm{nVE}$ i $\mathrm{B}=1 \mathrm{u} A D=1 \mathrm{iVE}$

$1 \mathrm{n} \mathrm{AD} \mathrm{iC}=1 \mathrm{n}$ VE i $\mathrm{C}=1 / 2 \mathrm{u} A D=1 / 2 \mathrm{iVE}$

$1 \mathrm{n} \operatorname{VE}$ i $\mathrm{A}=2 \mathrm{n} \mathrm{VE}$ i $\mathrm{B}=4 \mathrm{n} \mathrm{VE}$ i $\mathrm{C}$

$\mathrm{n} \mathrm{AD}=$ national arbejdsdag

$\mathrm{n} \mathrm{VE}=$ national valutaenhed

$\mathrm{u} \mathrm{AD}=$ universel arbejdsdag

$\mathrm{i} \mathrm{VE}=$ international valutaenhed

En national arbejdsdag i nation A kommer følgelig til udtryk i større internationale pengesummer end en national arbejdsdag i landene B og C. « ${ }^{34}$

»Under disse forudsætninger antager den internationale markedsværdidannelsesproces følgende form: Varepriserne i alle brancher, hvis arbejdsprodukter skal afhændes på verdensmarkedet, transformeres, når de forlader den nationale cirkulationssfære, til internationale valutaenheder først og fremmest ved hjælp af vekselkursen. Denne pengenavnsmetamorfose svarer til en vægtningsproces. Hvert nationalt arbejdskvantum, der viser sig på verdensmarkedet, vægtes via vekselkursen værdimæssigt med den plads, som den pågældende nationale kapital i gennemsnit indtager på det universelle arbejdes rangstige. Den højest udviklede nations arbejdskvanta er $n \phi d t$ til at komme til udtryk i høje internationale værdier, fordi den gennemsnitlige grad af arbejdsintensitet og den branchespecifikke produktivitetsgrad i dette land ligger over det internationale gennemsnit; omvendt er arbejdskvanta fra $\varnothing$ konomisk svagt udviklede nationer $n \phi d t$ til at komme til udtryk i lavere internationale værdier.

På verdensmarkedet konfronteres varer, som alle har gennemløbet denne landsspecifikke vægtningsproces, og på basis af disse internationale »udbudspriser« dannes der så internationale markedsværdier i de forskellige verdensmarkedsbrancher. Den form, hvori denne markedsværdidannelse forløber, kan i den forbindelse fuldt ud sammenlignes med den tils-

34. Ibid. si. 39-40, da.udg. s. 31-32. 
varende proces inden for nationale produktionsgrene. De mest udbredte produktionsbetingelser bestemmer verdensmarkedsprisernes tyngdepunkt, når udbud og efterspørgsel svarer til hinanden; falder produktion og markedsbehov ikke sammen, får den anden bestemmelse af samfundsmæssigt nødvendigt arbejde indflydelse på markedsværdiens konstitueringsproces inden for de tidligere beskrevne grænser.

Men hvorvidt kan man nu tale om en modifikation af værdiloven på verdensmarkedet? Hvilke er de specifikke forskelle mellem værdilovens virkemåde inden for mationale rammer og dens bevægelsesformer på verdensmarkedet? Det centrale i værdilovens modifikation på verdensmarkedet er følgende to momenter:

1. Mens konkurrencekampen inden for nationale rammer på en uformidlet måde udsætter de svagere producenter for de højt udviklede kapitalers overlegne produktivkraft, bliver de økonomisk svagere udviklede nationer beskyttet mod de højest udviklede nationers ødelæggende konkurrencekraft igennem det forhold, at den internationale konkurrence kamp formidles over grænsepælene for de nationale cirkulationssfærer, valutakurserne. Også i de tilfælde at de mindre udviklede nationer i alle industrigrene producerer med mindre arbejdsproduktivitet end de højere udviklede lande, kan de følge med i den internationale priskonkurrence, fordi deres høje nationale varepriser via vekselkursen transformeres til lavere internationale priser, og fordi de mere udviklede lande omvendt er nødt til via forholdet mellem valutaerne at forvandle deres lave nationale varepriser til højere internationale priser.

Denne beskyttelsesmekanisme, som den internationale værdilov implicerer for de svagere udviklede nationer, repræsenterer en væsentlig modifikation af værdiloven. Denne mekanisme er også årsag til, at der i varekapitalrelationerne mellem de forskelligt udviklede nationer kan etableres en international arbejdsdeling. Da forholdet mellem valutaerne genspejler den gennemsnitlige intensitets- og produktivitetsrang, som de enkelte nationer indtager på det universelle arbejdes rangstige, mens der ved siden af industrigrene med gennemsnitlige produktionsbetingelser også eksisterer produktionssfærer, hvis niveau ligger over og under gennemsnittet, er valutakursmekanismen i enhver nation til ulempe for de industrigrene, hvis produktive kapacitet ligger under gennemsnittet. I de højtudviklede lande påtvinger valutakursmekanismen industrigrenene med produktionsbetingelser under gennemsnittet så høje internationale priser, at de kan udkonkurreres af de tilsvarende brancher i de mindre udviklede nationer, selv om de eventuelt er i stand til at producere mere produktivt $\mathrm{i}$ absolut forstand 
end sidstnævnte; i de mindre udviklede lande beskytter valutakursmekanismen ikke i tilstrækkelig grad de produktionssfærer, som ligger under gennemsnittet, mod de højere udviklede nationers overlegne konkurrencekraft og lader dem derfor bukke under i den internationale konkurrencekamp. På denne måde institutionaliserer de internationale varekapitalrelationer formidlet over valutakurserne en international arbejdsdeling på basis af komparative omkostningsfordele, dvs. en arbejdsdelt struktur, der ikke er mulig inden for nationale rammer, fordi de svagere producenter her uden beskyttelse er udleveret til de højt udviklede kapitaler. $\ll^{35}$

Sammenfattet er Busch' resultat følgende:

$\mathrm{Vi}$ antager at en enhed af vare $\mathrm{X}$ i land $\mathrm{B}$ fremstilles på en arbejdsdag. I land A bruger man - analog til produktivitetsforskelle - kun en halv dag til produktionen og $\mathrm{i}$ land $\mathrm{C} 2$ dage.

Hvis producenten fra land $\mathrm{A}$ ville sænke prisen på vare $\mathrm{X}$ af hensyn til konkurrencen på verdensmarkedet, ville han pga. de nationale valutaers mellemkomst modtage mindre arbejdstid udtrykt i den nationale valuta, end han i virkeligheden havde lagt ud til produktionen af vare X. Producenten fra land $\mathrm{A}$ kan således ikke udnytte sin produktivitetsfordel på verdensmarkedet, hvilket han havde kunnet, hvis alle tre havde produceret i samme land.

Hos Klaus Busch er det således alene de producenter, hvis produktivitet afviger mere fra det internationale niveau end deres lands produktivitetsniveau i gennemsnit afviger herfra, som pga. deres større produktivitet råder over konkurrencefordele på verdensmarkedet.

På den anden side vil de producenter, der nok producerer mere produktivt end det internationale gennemsnit, men hvis afstand fra dette gennemsnit er mindre end afstanden fra deres nations samlede produktivitetsniveau til verdensmarkedsniveauet, på verdensmarkedet ligge under for konkurrencen fra mindre produktive producenter fra andre nationer - trods deres produktivitetsfordele.

Alt i alt er der således på verdensmarkedet tale om ganske voldsomme afvigelser fra konkurrenceprincipperne inden for en nation og også om en indlysende forklaring på, at den internationale arbejdsdeling reguleres efter

35. Ibid. s. 41-42, da.udg. s. 33-34. Den anden modifikation følger af den første: »Mens de kapitaler, hvis produktive kapacitet ligger over gennemsnittet, kan tilegne sig merprofitter i den nationale konkurrencekamp, er tilegnelsen af ekstraprofitter kun forbigående mulig for de højere udviklede nationale kapitaler i den internationale konkurrencekamp.« (s. 43, da.udg. s. 35. De er kun mulige indtil valutapariteten har tilpasset sig forholdet mellem landenes produktivitetsniveauer (jvf. s. 44 ff, da.udg. s. 36). Eftersom denne anden modifikation er bygget op på den fejlagtigt bestemte første modifikation vil jeg ikke behandle den her. 
princippet om sammenlignelige fordele. Dette princip er netop baseret på, at en nation som på alle områder har en undergennemsnitlig produktivitet skal kunne specialisere sig på verdensmarkedet i produktionen af en vare, hvor afstanden i produktivitet til det internationale niveau er mindst. Det ser ud som om at Klaus Busch (og med ham de andre tilhængere af denne teori) på det abstrakte niveau for udviklingen af værdiloven har påvist en udtalt og vidtrækkende modifikation af værdiloven på verdensmarkedet en modifikation som udelukkende skulle være opstået derved, at pengene som almen ækvivalent har internationalt forskellige navne, derved altså, at der eksisterer forskellige valutaer.

Er denne påvisning korrekt, er det ikke tilstrækkeligt at tale om en modifikation af værdiloven på verdensmarkedet, men om dens ophævelse. Den ideelle reduktion af det individuelle (nationale) arbejde til det samfundsmæssigt (internationale) nødvendige omfang ville ikke finde sted den virkelige reduktion ville være forsvundet.

Med disse overvejelser arbejder både de neomarxistiske teoretikere som jeg tidligere har nævnt ${ }^{36}$ og også deres kritikere ${ }^{37}$, som sætter ind med deres kritik på et senere niveau. Jeg vil nu vise, at denne kritik af »teorien om værdilovens modifikation på verdensmarkedet «ikke først og fremmest må sættes ind mod de slutninger, dens tilhængere drager, men mod dens kerne: »arbejdsværdigrundlaget for disse internationale penge- og prisbevægelser.«

Vi vil nu gå tilbage til det sted hos Marx i kap. 20 i Kapitalens 1. bind, som denne teori bygger på.

»De forskellige mængder af varer af samme art, der i forskellige lande produceres i løbet af den samme arbejdstid, har altså forskellig international værdi, hvad der kommer til udtryk i forskellige priser, dvs. i pengesummer, der varierer med de internationale værdier. «39

Hvis vi starter på samme måde som i Klaus Busch' model, har vi at vare $\mathrm{X}$ fremstilles i land A på $1 / 2$ arbejdsdag, $\mathrm{i}$ land B på 1 arbejdsdag og i land $\mathrm{C}$ på 2 arbejdsdage.

36. C. Neusüss, Busch, Schoeller men også Altvater og Goralzcyk for at nævne nogle går ud fra dette.

37. C. Neusüss, Busch, Schoeller men også Altvater og Goralzcyk for at nævne nogle går ud fra dette.

38. Eksempelvis er fremstillingen af vekselkursmekanismen yderst problematisk hos Neusüss og Busch. Wolfgang Schoeller har mht. dette allerede $\varnothing$ vet (selv-) kritik, op.cit.

39. Det samlede citat er tidligere trykt i afsnit c) i denne artikel. Det findes iøvrigt hos Marx inden for rammerne af en anden problemstilling end den vi behandler her, hvad kapitaloverskrifterne viser: »Nationale forskelle i arbejdslønnen«, og der er heller ikke tale om præcise formuleringer. 
De internationale penges værdi svarer til 1 universel arbejdsdag. Herudfra kan man formalisere Marx' udsagn på følgende måde:

$1 \mathrm{n} A D$ i $\mathrm{A}=2 \mathrm{X}=2 \mathrm{u} \mathrm{AD}=2 \mathrm{iVE}$

$1 \mathrm{n} \mathrm{AD} \mathrm{i}=1 \mathrm{X}=1 \mathrm{u} \mathrm{AD}=1 \mathrm{iVE}$

$1 \mathrm{n} A D$ i $C=1 / 2 X=1 / 2$ u AD $=1 / 2 \mathrm{iVE}$

Så langt stemmer Klaus Busch' model overens med Marx' udsagn. Det, der er galt hos Klaus Busch, er fortolkningen af dette udsagn og bestemmelsen af forholdet mellem den nationale og den internationale valuta. Inden vi behandler denne forkerte bestemmelse skal vi for at tydeliggøre konsekvenserne eftervise, hvad der sker i et samfund, der kun har en almen ækvivalent, én type penge, når de enkelte producenters produktivitet er forskellig.

$\mathrm{Vi}$ antager således at $\mathrm{A}, \mathrm{B}$ og $\mathrm{C}$ er producenter i et samfund med en type penge (P). Her gælder præcis hvad Marx har sagt i forbindelse med ekstramerværdien: Producent A forbruger kun det halve af den arbejdstid til produktion af vare $X$, der ville være nødvendig i forhold til det samfundsmæssige gennemsnit. Så længe at værdien af vare $X=1$ gennemsnitlig arbejdsdag $=1 \mathrm{P}$ får han i byttet ækvivalenten for mere arbejdstid end han selv har forbrugt. ${ }^{40}$ Her $»$ hvor arbejdets produktivitet er usædvanlig høj virker det som potenseret arbejde eller skaber i samme tidsrum højere værdier end samfundsmæssigt gennemsnitsarbejde af samme art. $\ll^{41}$ Eftersom han i virkeligheden har færre omkostninger end de andre producenter - idet arbejdstid er målestok for produktionsomkostningerne - kan han sænke sin pris til $1 \frac{2}{2} \mathrm{P}$ i konkurrencen om at sælge vare $\mathrm{X}$ og dog stadig mindst få sine reale omkostninger dækket.

Dette vil han oftest også gøre, idet mere produktivt arbejde tillige betyder, at han producerer flere varer end tidligere. Dette betyder igen, at totaliteten af de producerede varer X kun kan afsættes når deres pris falder forudsat et givet betalingsdygtigt samfundsmæssigt behov. Den prissænkning, som producent A gennemfører har en af to mulige følger for de andre producenter: enten må de forøge deres produktivitet, hvorved de også uden tab kan afsætte deres varer til de faldende priser, eller de kan ikke forøge deres produktivitet og kan derved ikke følge med i konkurrencen med det resultat, at de forsvinder ud af markedet.

40. Her skal endnu engang henvises til, at bytte til værdier er en hypotese, som svarer til analysens logiske niveau. I virkeligheden byttes der til produktionspriser, men også her virker produktivitetsstigningen hos en producent ind, således at han med samme pris får en højere profitrate eller kan sænke prisen pga. lavere produktionsomkostninger.

41. Das Kapital bd. 1, s. 337, da.udg. 1.2 s. 477. 
Værdiloven som formidling mellem samfundsmæssige behov og fordeling af det samfundsmæssige arbejde, tilvejebringer ikke blot en fælles vareværdi, men også en virkelig tilpasning af det gennemsnitlige samfundsmæssigt nødvendige arbejde til det stigende produktivitets- (og intensitets-) niveau, idet den via konkurrencen tvinger mindre produktive producenter til at forøge deres produktivitet eller forsvinde ud af markedet.

Heroverfor hævder Klaus Busch, at denne virkelige gennemsættelse af det samfundsmæssigt nødvendige arbejde på verdensmarkedet forhindres af de forskellige nationale valutaer. Som det også fremgår af hans eksempel ville den mest produktive nations kapitaler lide tab, hvis de ville sænke verdensmarkedsprisen på deres varer i overensstemmelse med deres højere produktivitetsniveau. Denne konsekvens fremkommer hos Busch fordi han lader »nationale « og »internationale « værdier eksistere side om side $\mathrm{i}$ virkelighedens verden og - i sammenhæng hermed - fordi han bestemmer pengene forkert.

Penge er ikke en målestok for arbejdstid, som det hedder hos Klaus Busch med ligestillingen $1 \mathrm{n} \mathrm{AD}=1 \mathrm{n} \mathrm{VE}$, men penge er - på det niveau, hvor værdiloven udvikles - selv en vare, hvis værdi er bestemt af den samfundsmæssig nødvendige arbejdstid, der medgår til denne vares produktion. Som almen ækvivalent tjener denne vare som målestok for de andre varers værdi. ${ }^{42}$

Efter denne bestemmelse kan man mht. bestemmelsen af de internationale penges værdi være enig med Klaus Busch. Vi antager begge, at de internationale penges værdi - eksempelvis varen gulds - er bestemt af den internationale samfundsmæssige nødvendige arbejdstid, der medgår til dens produktion. Men mht. bestemmelsen af de nationale valutaers værdi kommer jeg som følge af ovenstående fremstilling til et andet resultat end Klaus Busch. Når de enkelte lande, som tilsammen udgør verdensmarkedet, har forskellige valutaer, kan det kun betyde ét af to: enten fungerer en anden vare som almen ækvivalent i et land (f.eks. sølv i land A og kobber i land C) eller også har de også varen guld som penge og deres valutaenhe-

42. Jvf. Das Kapital bd. 1, kap. 3. I lyset af dette kapitel er Marx upræcis i kapitel 20, når han skriver: »Pengenes relative værdi vil altså være mindre hos den nation, der har en mere udviklet kapitalistisk produktionsmåde end hos den nation, hvor den er mindre udviklet.« Hvad han bør have ment med dette i lyset af kapitlerne om pengene er; med udgangspunkt i det relative værdiudtryk kan der i det mere produktive land købes mindre legemeliggjort arbejdstid med internationale penge end i det uproduktive - eller med udgangspunkt i de internationale penges værdi, så skal der anvendes mindre arbejdstid i det mere produktive land end hvad der er internationalt gennemsnitlig nødvendigt. 
der udtrykker forskellige mængder guld (f.eks. kunne valutaenheden i land A hedde daler og svare til 2 ounze guld og i land $\mathrm{C}$ hedde rubel og være navnet for $1 / 2$ ounze guld). I metodisk forstand er der herved ingen forskel på de nationale valutaers forhold til verdenspenge. I begge tilfcelde er forholdet mellem de nationale valutaer bestemt af forholdet mellem deres internationalt bestemt vardier.

Dette er umiddelbart indlysende i det tilfælde, hvor de nationale valutaer kun udtrykker forskellige mængder guld. Men også i den situation, hvor forskellige varer tjener som almen ækvivalent i de nationale valutaer, er der tale om samme forhold. For så vidt, at verdensmarkedet er forudsat, er alle varers værdi internationalt bestemt og der findes ikke længere nationale værdier; der kan højst være tale om nationale forskelle i den arbejdstid, der er genstandsgjort i varen. Og dette gælder også for varen penge. Analog til vort eksempel er eksempelvis forholdet mellem den nationale valuta sølv og verdenspengene guld lig forholdet mellem deres internationale værdier. Her spiller nationale produktivitetsniveauer kun en rolle i den udstrækning, de indgår i bestemmelsen af de internationale værdier. ${ }^{43}$

Klaus Busch' tilsyneladende så indlysende forklaring på værdilovens modifikation på verdensmarkedet beror på den fejl, at den på den ene side antager, at alle varer på verdensmarkedet får en international værdi og på den anden side, at varen penge har en national bestemt værdi i samme $\varnothing$ jeblik denne vare repræsenterer en national valuta. Årsagen til hele denne misere skal søges $i$ hans antagelse om det indre markeds normalitet $\mathrm{i}$ forhold til verdensmarkedet og $\mathrm{i}$ en implicit overtagelse af den teori om arbejdspenge, som Marx skarpt kritiserer på følgende måde:

»Det spørgsmål, hvorfor pengene ikke umiddelbart repræsenterer arbejdstiden selv, således at f.eks. en pengeseddel forestiller X arbejdstimer, er ganske simpelt det samme som spørgsmålet, hvorfor arbejdsprodukterne på grundlag af vareproduktionen må optræde som varer; for den måde, varen fremtræder på, indbefatter dens tvedeling i vare og pengevare. Eller hvorfor privatarbejde ikke kan behandles som umiddelbart samfundsmæs-

43. At forholdet mellem de nationale penge og de internationale kun kan være bestemt gennem deres internationale værdier og ikke, som Klaus Busch tror, halvt gennem de internationale værdier og halvt gennem de nationale værdier, kom Japan allerede i det 19. århundrede på sporet af. Da Japan dengang åbnede sig mod verdensmarkedet blev der holdt fast ved et nationalt (japansk) bytteforhold mellem guld og sølv: 1 G 5 S. Dette svarede ikke til det internationale bytteforhold på $1 \mathrm{G} 15 \mathrm{~S}$. Klaus Busch må nu mene, at de japanske producenter af verdensmarkedsgoder herigennem rådede over en enorm konkurrencefordel på verdensmarkedet. Resultatet var imidlertid at sølv blev eksporteret til Japan som derigennem solgte guld, som igen blev eksporteret fra Japan. Og selv i de tilfælde, hvor der blev solgt japanske varer for sølvet, lignede det mere et sommerudsalg end en forøgelse af akkumulationsraten. 
sigt arbejde, som sin egen modpart. Jeg har andetsteds redegjort udførligt for den overfladiske utopisme, der ligger $\mathrm{i} »$ arbejdspenge « som grundlag for vareproduktionen (»Bidrag til kritikken af den politiske økonomi « (se Dietz-udg. bd.13, s.6-6ff)). Her skal kun tilføjes, at f.eks. Owens »arbejdspenge « ikke er mere penge end et garderobemærke er det. Owen forudsætter umiddelbart fællesgjort arbejde, en produktionsform, der er diamentralt modsat vareproduktionen. Arbejdscertifikatet konstaterer kun producentens individuelle andel i fællesarbejdet og hans individuelle krav på den del af fællesproduktet, der er bestemt til forbrug. Men det falder ikke Owen ind at forudsætte vareproduktionen og alligevel forsøge på at omgå dens nødvendige betingelser ved hjælp af pengeprojekter. «4

Den forvandling, der sker med en vare fra dens nationale til dens internationale prisudtryk, modsvares i en korrekt bestemmelse af den nationale valutas værdi af en udelukkende formel, numerisk forandring af værdiens målestok. I det ene øjeblik tjener den vare, der kaldes iVE (international værdienhed), og som er udtryk for 1 legemeliggjort universel arbejdsdag, som målestok for alle andre varers værdi, og i det andet $\varnothing j$ jeblik tjener den vare, der kaldes n VE (national valutaenhed), og som er udtryk for m universelle legemliggjorte arbejdsdage, som målestok. På denne måde kan producenterne i det overgennemsnitligt produktive land sænke prisen på deres varer på verdensmarkedet analogt til deres produktivitetsfordel uden at det fører til tab, præcis som jeg tidligere har fremstillet det i forbindelse med et samfund, hvor der kun er én slags penge, en almen ækvivalent.

Det lighedstegn mellem 1 national arbejdsdag og 1 national valutaenhed, som Klaus Busch tvinges til at antage i sin model er således forkert. Hvis man nu i hans model indfører den eneste bestemmelse af den nationale valuta, der er korrekt i forhold til dette abstraktionsniveau, som værende varer med international værdi, så bryder hele teorien om værdilovens modifikation på verdensmarkedet sammen. Det skulle således også være overflødigt at gå videre med behandlingen af de fejl, som forfatterne begår i forsøget på at omsætte deres fejlagtige teori til realiteternes verden.

Tilbage er to vigtige tankegange, som ligger bag denne teori:

a) Tilløbet til at behandle verdensmarkedet som noget, der ikke er udvendigt i forhold til de nationale $\varnothing$ konomier, men at se disse som en del af enheden verdensmarked. Det forbliver imidlertid ved tilløbet, som det ses af bestemmelsen af den nationale valuta.

44. Das Kapital bd. 1, s. 109, da udg. 1.1 s. 197, note 50. 
b) Overvejelser om, at ændringer i valutapariteten kan influere på verdensmarkedskonkurrencen. Dette kan imidlertid netop ikke eftervises på værdilovens niveau, hvor pengene må behandles direkte som varer, og hvor man derfor må gå ud fra en neutralitet og ikke-manipulerbarhed hvad angår vekselkurser. Men da pengene i virkeligheden blot er formidlede repræsentanter for en vare, og da vekselkurserne kan påvirkes af nationalstatslige foranstaltninger, så kan man i en konkret analyse af de internationale $\varnothing$ konomiske forhold ikke se bort fra en behandling af vekselkurserne. En sådan undersøgelse forudsætter mere udviklede analyser, end hvad der er muligt på værdianalysens niveau.

Teorien om værdilovens modificerede funktion på verdensmarkedet virker ikke bare desorienterende, fordi den alene vil behandle problemerne i kapitalens verdensmarkedsbevægelser som den påstår at forklare ud fra værdiloven, og gør dette på et forkert analytisk niveau, men også fordi denne teori ikke konsekvent holder fast ved postulatet om, at verdensmarkedet er den kapitalistiske produktions livsatmosfære og basis, og således baserer hele sin udsagnskraft på en logisk fejl. Først og fremmest virker den dog desorienterende, fordi den nok henviser til kapitalernes nationalstatslige organisering, men samtidig præcis bortdefinerer dette forhold fra analysen af kapitalens verdensmarkedsbevægelse gennem sin tilbagevenden til rene $\varnothing$ konomiske forklaringer. Det bortdefinerede definerer således forskellen mellem Marx' logiske konstruktion med en ensartet kapitalisme og den virkelige kapitalisme, hvor herredømmet ikke er organiseret i en verdensstat, men i nationalstater. Klaus Busch er mest insisterende $\mathrm{i}$ at fastholde denne udelukkelse, idet han konsekvent omtaler og også behandler de afhængige - og heri ligger også forestillingen om dominans - kapitalistiske lande som » $\varnothing$ konomisk svagt udviklede lande «. Det er nu engang et faktum, at herredømmet i den virkelige kapitalisme er nationalt organiseret. Den modificerende funktion, som nationalstatens eksistens har på de almene love for fordeling af det samfundsmæssige arbejde i kapitalismen, består netop i, at grundprincippet i disse love, ifølge hvilket det kun i snæver forstand er $\varnothing$ konomiske, »markedsmekanistiske« love, som spiller en rolle i den fordeling, bliver brudt. Rent økonomisk er der intet nyt at forklare på verdensmarkedet, eftersom politik med kapitalernes nationalstatslige organisering er blevet en integreret del af den internationale konkurrence.

Det bestemmende princip i den kapitalistiske produktionsmåde er rent $\emptyset$ konomisk: kapitalvalorisering. Af denne grund var det også korrekt af Marx, at han eliminerede faktoren politik i sin logiske rekonstruktion af det borgerlige samfunds anatomi. Ligeledes er det rigtigt at forstå politik som for så vidt afledt af $\emptyset$ konomien, eftersom enhver politik, som inden 
for systemet forholder sig dysfunktionelt til kapitalvaloriseringen, på lang sigt er dømt til at forsvinde.

I denne forstand kan man tale om $\varnothing$ konomiens primat i kapitalismen og i det kapitalistiske verdenssystem. Det er imidlertid forkert at forstå dette primat således, at det udelukkende er den økonomiske udvikling som spiller en rolle i den konkrete analyse, og at politik kun kan tilpasse sig halvvejs afmægtigt.

Hvad angår verdensmarkedsanalysen, må postulatet om $\varnothing$ konomiens primat ikke forstås derhen, at man først går frem efter rent økonomiske synspunkter og først senere indfører politikken som en extern faktor. Kapitalvaloriseringen rummer samtidig herredømmeforhold. (Af samme grund har Marx undersøgt dens lovmæssigheder!) Den internationale konkurrence er samtidig en kamp om et nationalt organiseret herredømme, og politikken kan - selvom den nok kan afledes af kapitalens valoriseringsinteresser men dog altid en bestemt national kapitals interesser - helt afgørende påvirke de betingelser, som denne konkurrence finder sted under.

Den $\varnothing$ konomiske automatik, som tilhængerne af teorien om værdilovens modificerede gennemsættelse mener at have fundet, er ikke bare umulig at eftervise - den blokerer ydermere for at se følgerne af kapitalens nationalstatslige organisering: statens forholdsregler virker pga. deres nationale karakter ikke ens på alle kapitaler; den socioøkonomiske og politiske integration og udvikling i deres respektive oprindelseslande spiller en afg $\varnothing$ rende rolle i kapitalernes internationale konkurrencekamp (og omvendt); en nations og dermed også dens kapitalers internationalt førende stilling bliver ikke kun forsvaret med økonomiske midler, men også politisk og militært. Kort og godt: med fremmaningen af en - godt nok forkert - ren $\varnothing$ konomisk automatisk modifikation af den internationale arbejdsdeling, står denne teori i vejen for en kritik af det kapitalistiske verdenssystems politiske økonomi. 


\section{Introducerende note til Bernhard Blanke: Socialdemokrati og samfundskrise}

\section{Nils Bredsdorff og Leif Hansen}

Den følgende artikel er oprindeligt trykt i Wolfgang Luthardt, (red.): Sozialdemokratische Arbeiterbewegung und Weimarer Republik. Materialien zur gesellschaftlichen Entwicklung 1927-1933, 2. Bd., Frankfurt/M 1978, der omkring en række centrale problemstillinger har genoptrykt tekster fra den omhandlede periode og forsynet disse med kortere indledningsartikler. I denne sammenhæng står Blankes artikel dog ikke som indledning til et tekstudvalg, men netop som materialesamlingens afsluttende, forsøgsvise syntetiserende bidrag.

Socialdemokrati og samfundskrise kalder Blanke sin artikel, men den vigtigste pejling til forståelsen af artiklens hovedsigte fås af undertitlen: Hypoteser til en socialvidenskabelig reformismeteori. Grundlaget - den historiske ramme om man vil - for artiklen er debatten om arbejderbevægelsens (specielt den socialdemokratiske) rolle under Weimarrepublikken, men sigtet er teoridannende.

Blankes projekt er at nå frem til en forståelse af de strukturer i kapitalismen, der gør den reformistiske arbejderbevægelse i stand til ikke blot at overleve alle sine nederlag (og Weimarrepublikkens sammenbrud er et af de store), men til at genopstå styrket og vital.

Artiklen er på den ene side et opgør med de gængse forklaringsmønstre (både borgerlige og marxistiske) omkring (Weimar-) reformismen, som enten ser reformismen som handlingsblokerende for en i sig selv revolutionær eller i det mindste reformivrig arbejderklasses krav, eller som ser reformismen som en bevidst valgt strategi for en arbejderbevægelse, der har ladt de socialistiske forhåbninger bag sig. I sin kritik af den meget omfattende litteratur om weimarperiodens socialdemokrati er artiklen naturligvis bundet til den historiske periode. Men selvom en del af dens pointer måske forudsætter en del viden om den samfundsmæssige udvikling før og under Weimarrepublikken (hvilket bl.a. kan hentes i det to-binds-værk artiklen afslutter), så leverer artiklen samtidig et godt grundlag for at rydde ud i myterne $\mathrm{i}$ diskussionen af baggrunden for overgangen til det fascistiske barbari.

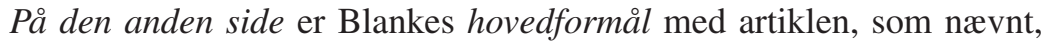
noget bredere, nemlig i egentligste forstand teoridannende. Det drejer sig for det første om et opgør med de samfundsteoretiske forudsatninger for de kritiserede analyser hhv. reformismeteorier. 
For det andet er det et fors $\emptyset \mathrm{g}$ på at skitsere en teori om reformismen, som ikke tager sit udgangspunkt i de politiske handlinger, der er et udtryk for konflikten mellem lønarbejde og kapital, men derimod i de samfundsmæssige strukturer, som sætter både modsætningen mellem lønarbejde og kapital $o g$ betingelserne for denne modsætnings temporære ophævelse eller bedre dens forskellige bevægelsesformer.

Og hermed har vi allerede antydet det tema, der behandles i artiklens indledning og 1. tese: Artiklens ofte stikordsagtige kritik af de teoretiske forudsætninger for de herskende reformismeforklaringer (og det er igen vigtigt at præcisere, at det gælder såvel de borgerlige som de marxistiske) kan sammenfattes under begrebet handlingsteori. Blanke hævder, efter vores mening med rette, at de eksisterende analyser fra Wehler over Groh til Abendroth og Fülbert/Harrer (det samme gælder i $\varnothing$ vrigt for størstedelen af den danske reformismediskussion, jvf. kritikken af de »socialhistoriske « bidrag i Bredsdorff $m$. $f$. i Kurasje 21) basalt har samme samfundsteoretiske udgangspunkt: Samfundet forstås som en »handlingssammenhæng«, dvs. samfundets strukturer og institutioner og ændringer heri forstås alene udfra og som et resultat af (formålsbestemt) individuel eller kollektiv handlen.

Der kan være grund til at knytte nogle få bemærkninger til dette forhold, da det er temmelig centralt for artiklen, men samtidig i sin knappe form kan være vanskeligt at overskue, eftersom Blanke med den indledende kontrastering mellem handlingsteori og systembetragtning (uden i $\varnothing v$ vrigt selv at gøre opmærksom derpå) skriver reformismedebatten ind i et af de væsentligste samfundsvidenskabelige stridsemner: Hvilke af disse teoretiskmetodiske udgangspunkter skal man tage ved analysen af samfundet?

Siden begyndelsen af dette århundrede har der inden for samfundsvidenskaberne eksisteret en stærk og efter trediverne dominerende og til tider næsten enerådende tradition, der på grundlag af en »metodologisk individualisme « har taget udgangspunkt i individernes/aktørernes handlinger $\mathrm{i}$ forsøgene på at forklare samfundsmæssige strukturer og funktioner og $\mathrm{i}$ sidste instans også samfundet som system. Stikordsagtigt drejer det sig om den subjektive værditeori inden for $\emptyset$ konomien, om behavioralismen og strukturfunktionalismen inden for politologien. Disse teoriers praktiskpolitiske bias er ofte blevet kritiseret gennem årene (f.eks. deres im- og eksplicitte regulerings- og manipulationsintention), hvorimod deres teoretisk-metodiske grundlag stadig står forholdsvis uantastet tilbage ofte kun postulatorisk modstillet til en marxistisk system/totalitetsbetragtning. 
Det er imidlertid ikke de fundamentale problemer i den handlingsteoretiske samfundsteori Blanke indledningsvis (utilladeligt kort) polemiserer imod, men snarere mod resultaterne af en - oftest implicit - anvendelse af et sådant udgangspunkt i historieforskningen, in casu om reformismen. Det afgørende problem er, at udgangspunktet ikke gør det muligt at unders $\emptyset$ ge spørgsmålet om de samfundsmæssige/systemsatte betingelser for og virkninger af den politiske handlen. Dette giver sig bl.a. udslag i den relative vilkårlighed, med hvilken forskellige historikere fremhæver eller udelader bestemte samfundsmæssige forhold i deres reformismeforklaring.

Heroverfor fors $\emptyset$ ger Blanke at arbejde videre med begreber, som er udviklet tidligere i den statsteoretiske debat. Det drejer sig om det i artiklen kun implicit forudsatte begreb om transformationen af herredømme-konflikten til en fordelingskonflikt, som strukturelt er sat af den form, hvori forholdet mellem lønarbejde og kapital fremtræder. Og om det hér ligeledes blot forudsatte begreb om retten og pengene som forhåndsstrukturerende for de agerendes handlingshorisont (jvf. kort Kurasje nr. 21, s. 37 ff). I fors $\varnothing-$ get på at konkretisere og videreudvikle disse bestemmelser til en historisk analyse fastholder Blanke sit »systemudgangspunkt « og gør det endog på en ret provokerende måde, idet han (jvf. note 6): »forsøger at overføre impulser fra den funktionel-strukturelle systemteori (Niklas Luhmanns systemteori, NB \& LH) på det marxistiske paradigma «. Det sker i en præcisering af begreberne systemgranser og aktivitetsgranser for de statlige tiltag, men først og fremmest i forsøget på at bestemme det i artiklen helt centrale begreb: Reformers funktionelle ambivalens.

Overfor Luhmanns position, at den samme funktion kan opfyldes af forskellige strukturer og processer, der er komplementære (funktionel ækvivalens) vil Blanke med begrebet funktionel ambivalens angive, at den samme funktion er bestemt af forskellige relationer, der netop ikke er komplementære, men antagonistiske/modsigelsesfulde og historisk bestemte, hvilket gør processen og strukturen i funktionsopfyldelsen ambivalent (jvf. også B. Blanke. Entscheidungsanarchie und Staatsfunktionen, in: $R$. Ebbighausen (red), Bürgerlicher Staat und politische Legitimation, F/M 1976, s. 188 f.).

I analysen af reformerne, der opfattes som problemløsninger og konfliktreguleringer, viser Blanke nu, hvordan reformerne i deres gennemsættelsesproces er bundet til disse modsigelsesfyldte relationer uden umiddelbart selv at udtrykke modsigelserne, og hvordan reformerne gennem vedvarende institutionalisering udvikler sig til et system til reproduktion af lønarbejdet. Der er ikke tale om konstruktionen af et system, inden for hvis 
rammer individerne handler, og som derfor altid i sidste instans kan påkaldes som forklaringsinstans overfor uforklarlige eller uønskede handlinger eller konsekvenser heraf. Derimod er der tale om en begrebsliggørelse af forhold, som under kapitalismen tvangsmæssigt strukturerer handlinger og deres institutionalisering, individernes forståelse af disse handlinger og deres fors $\emptyset \mathrm{g}$ på at uddrage handlingsrettede strategier af denne forståelse.

Vi ser selv Blankes - ofte meget skitseprægede og komprimerede og ind i mellem uoverskuelige - analyse som et af de seneste års vigtigste bidrag inden for den marxistiske teoretiske debat om reformismens reproduktionsbetingelser og som et godt grundlag for en videreudvikling heraf og dermed også mere alment af forholdet mellem økonomi og politik under kapitalismen.

Samtidig aktualiserer Blankes artikel nødvendigheden af et videre arbejde med helt fundamentale samfundsvidenskabelige problemstillinger, som det ovennævnte forhold mellem »handlingsteori og »strukturteori«, idet artiklen demonstrerer, at en sådan afklaring er nødvendig også for den marxistiske teoriudvikling. 


\title{
Socialdemokrati og samfundskrise:
}

\section{Hypoteser til en socialvidenskabelig reformismeteori.}

\author{
Bernhard Blanke
}

\section{Indledning}

Når man beskæftiger sig med Weimarrepublikken, hvis skæbne stadigvæk knuer den videnskabelige og politiske diskussion i Forbundsrepublikken og nu atter i relation til den nye krise helt umiskendeligt dukker op af den kollektive fortrængning, så støder man i litteraturen om arbejderbevægelsen på en slags to-linie-diskussion. På den ene side står de bidrag, som $\mathrm{i}$ traditionen fra Bracher til H. Mommsen (trods alle forskelle) kører rundt om mønstret: socialdemokratiets manglende »kompromis- og handlingsevne «, og som projicerer »folkepartimodellen« tilbage i historien som et strategisk alternativ, hvorved samtidig arbejderklassens enhed medtænkes under socialdemokratisk ledelse - selvom det for det meste dog kun sker implicit. På den anden side står en »reformismekritik«, som konstruerer arbejderklassens forening under revolutionære fortegn som den strategiske vej ud af fasciseringsprocessen. ${ }^{1}$ Også her bliver der naturligvis argumenteret forskelligt. Alligevel reproducerer denne debat for det første skismaet »reform eller revolution« som strategisk grundmønster. Dette strategiske

1. Karl Dietrich Bracher: Die Aufløsung der Weimarer Republik. Eine Studie zum Problem des Machtverfalls in der Demokratie, Villingen 1971; Hans Mommsen: Die Sozialdemokratie in der Defensive: Der Immobilismus der SPD und der Aufstieg des Nationalsozialismus, in: Hans Mommsen (red.): Sozialdemokratie zwischen Klassenbewegung und Volkspartei, Frankfurt/M 1974, p. 106ff. Særlig tydelig er »folkeparti«perspektivet i den partinære historieskrivning som hos Heinrich Potthof: Die Sozialdemokratie von den Anfangen bis 1945, Kleine Geschichte der SPD, Bind 1, Bonn/Bad Godesberg 1974: Det andet perspektiv repræsenteres eksemplarisk af Georg Fülberth/Jürgen Harrer: Die deutsche Sozialdemokratie 1890-1913, Darmstadt/Neuwied 1974. 
grundmønster rummer imidlertid samfundsteoretiske implikationer, som er fælles i den forstand, at samfundet skal bestemmes som en handlingssammenhaeng. Thi kun indenfor denne kontekst er det muligt at strides så indædt om, hvorvidt reformer tvangsmæssigt fører til arbejderbevægelsens integration i det borgerlige samfund eller om de må betragtes og bruges som blotte midler på vejen til og i overgangen til den revolutionære omvæltning af samfundet. For det andet er grundlaget for de opfattelser, der argumenterer indenfor en handlingslogik ofte en (negativ eller positiv) evolutionsteori om det borgerlige samfund, hvad enten det nu drejer sig om industrisamfundsteorien eller om teorien om kapitalismens almene almene krise efter 1917 og om den lovmæssige overgang til socialismen. ${ }^{2}$

Men handlingsteori og evolutionsteori kan kun bringes i samklang med den omkostning, at kriserne i det borgerlige samfund enten under - eller overvurderes alt efter evolutionsteoriens telos. De historiske og socialvidenskabelige arbejder, der nærmest har en legitimatorisk hældning i forhold til socialdemokratiets udvikling, vurderer f.eks. ikke krisen ved Weimarrepublikkens slutning som så graverende i dens tvangslovmæssighed ${ }^{3}$, at republikken ikke kunne være blevet redet i sidste $\varnothing$ jeblik gennem en anden politik. Omvendt er de arbejder af marxistisk oprindelse i videste betydning, som står kritisk henholdsvis fjendtligt overfor socialdemokratiet, nærmest tilbøjelige til at bestemme verdenskrisen som en systemkrise af en sådan dybde, at et revolutionært omsving i Tyskland ikke blot var blevet programmatiskpolitisk nødvendigt, men også samfundsmæssigt muligt. I modsætning til deres proklamerede uforenelighed når begge retninger dog sluttelig ufrivilligt til enighed i kritikken af weimarsocialdemokratiets reformisme på netop det punkt, at reformismen har blokeret denne bevæ-

2. Som repræsentant for den første variant står arbejder som Hans-Ulrich Wehler: Theorieprobleme der modernen Wirtschaftsgeschichte, in: Gerhard A. Ritter (red.): Entstehung und Wandel der modernen Gesellschaft. Festschrift für Hans Rosenberg, Berlin 1970, eller Dieter Groh: Negative Integration und revolutionårer Attentismus. Die deutsche Sozialdemokratie am Vorabend des Ersten Weltkrieges, Frankfurt/Berlin/Wien 1973 (for den evolutionært begrundede integrationsteori). Som repræsentant for den anden variant jvf. f.eks. Dieter Fricke: Die deutsche Arbeiterbewegung 1869 bis 1914. Ein Handbuch über ihre Organisation und Tåtigkeit im Klassenkampf, Berlin 1976, eller Wolfgang Küttler/Gerhard Lozek: Die historische Gesetzmåssigkeit der Gesellschaftsformationen als Dialektik von Ereignis, Struktur und Entwizklung, in: ZFG, 1970, hefte 9, p. 1117 ff. For en kritik af den marxistisk-leninistiske historiemetodologi jvf. Heinz-Dieter Kittsteiner: Bewusstseinsbildung, Parteilichkeit, dialektischer und historischer Materialismus, in IWK, hæfte 4, s. 408ff. For en kritik af integrationsteorien se Volker Ullrich: Emanzipation durch Integration?, in Kritik der bürgerlichen Geschichtswissenschaft II, Das Argument, nr. 75, s. 104ff.

3. Alfred Sohn Rethel: Ökonomie und Klassenstruktur des deutschen Fascismus, Frankfurt/M 1973. 
gelses handlinger. På den ene side beklages således den gammelkendte modsigelse mellem radikal teori og reformistisk praksis ${ }^{4}$, på den anden side bliver den socialdemokratiske arbejderbevægelses borgerliggørelse og skinradikalismens manipulative karakter hudflettet. ${ }^{5}$

Begge retninger tænker - dette skal være den første konstatering - ikke deres respektive tilgrundliggende samfunds-teoretiske ansatser konsekvent til ende. Thi hvis samfundet tænkes som system, hvor det i første omgang er uden betydning, om man analyserer på baggrund af Marx og Engels eller ud fra »moderne « funktionel-strukturelle sociologiske systemteorier, så kan handlingslogikken ikke længere udgøre et væsentligt analytisk referencepunkt for spørgsmålet om de politiske handlingers - især reformers - samfundsmæssige betingelser og virkninger. Handlingslogik, navnlig den som har sit empiriske tyngdepunkt i kildemæssigt dokumenterbare programmer og aktioner, bliver altid afhængig af netop dét udsnit af den samfundsmæssige realitet, i hvilken processer viser sig som handlinger og disses til enhver tid værende fortolkninger. Strukturer vil kun delvis kunne fattes og funktionelle sammenhænge kommer stort set ikke i betragtning. Denne mangel finder sit spejlbillede i den relative vilkårlighed som fremkommer, når overordnede, socialvidenskabelige teorier overføres til historiske analyser. De fleste af disse teorier er øjensynligt udviklet på et abstraktionsniveau, som ikke ubetinget korresponderer med relevant erkendelse om samfundet.

I de følgende fire teser til temaet socialdemokrati og samfundskrise forsøger jeg, gennem behandlingen af et særligt problem at overvinde kløften mellem »teori og historie«. Dette sker ved, at statsteoretiske overvejelser (der for en god dels vedkommende er et resultat af abstraktioner ud fra en historisk analyse af stats- og politikopfattelser) bliver relateret tilbage til analysen af historiske processer, specielt til tendenser i Weimarrepublikkens krise. $^{6}$

4. Om krisepolitikken efter 1929 jvf. Robert A. Gates: Von der Sozialpolitik zur Wirtschaftspolitik? Das Dilemma der deutschen Sozialdemokratie in der Krise 1929-1933, in: Hans Mommsen/Dietmar Petzina/Bernd Weisbrod (red.): Industrielles System und politische Entwicklung in der Weimarer Republik, Düsseldorf 1974, p. 206 ff.

5. F.eks. Erika Konig: Vom Revisionismus zum »Demokratischen Sozialismus«, Berlin 1973.

6. Mine tekster står fsv. videnskabslogisk på et lavere abstraktionstrin end debatten om historievidenskabens teoriproblemer (sammenlign bogen af samme navn, redigeret af Theodor Schieder und Kurt Gräubig, Darmstradt 1977; og: Peter Ludz (red.): Soziologie und Sozialgeschichte, Kölner Zeitschrift für Soziologie und Sozialpsychologie, Sonderhefte 16, Opladen 1972; Werner Conze: Sozialgeschichte; Hans Mommsen: Sozialgeschichte, in: HansUlrich Wehler (red.): Moderne deutsche Sozialgeschichte, Köln/Berlin 1966; Heinz-Dieter Kittsteiner: Theorie und Geschichte, in: Das Argument, nr. noten fortsættes 75, p. 18ff). Jeg forsøger at overføre impulser fra den funktionel-strukturelle systemteori på det marxistiske paradigme. Det »metodeanarki«, der muligvis opstår herved (set ud fra de respektive »sko- 
Men hvad betyder nu statsteoretisk? Ved forsøgene på at bestemme det politiske system ud fra forholdet mellem $\phi$ konomi og politik i det borgerlige samfund, støder man til stadighed på det problem, hvorledes det politiske systems funktionsområder skal udvikles ud fra andringer i de politisk- $\varnothing$ konomiske problemkomplekser. Især i forbindelse med statens såkaldte »sociale funktioner « spiller sociale bevægelser, partier og organisationer en afgørende rolle. Man bør vel at mærke ikke blot undersøge sådanne funktioners opkomst, men også deres afvikling ${ }^{7}$. I begge retninger opkomst og afvikling af sociale statsfunktioner - støder man uvægerligt på den socialdemokratiske arbejderbevægelse og dermed på reformismeproblemet. Det var jo netop denne type arbejderbevægelse, der blev såvel initiator som bærer af sådanne funktioner. Og samtidig er der ikke lykkedes denne bevægelse, hverken i den fatale krise eller i det tyske samfunds ombrydningsfase at forsvare de opnåede positioner og/eller at forhindre det politiske herredømmes overgang til diktatoriske former. Alligevel er denne reformistiske type arbejderbevægelse efter sine nederlag på ingen måde - som kritikerne havde ventet - gået bankerot ${ }^{8}$, men har derimod hver gang udfoldet sig i et nyt flor. Man kan altså konstatere kontinuiteten og først og fremmest ambivalensen i en bestemt politiktype, som ikke kun lader sig forklare ved hjælp af »tendenser « $\mathrm{i}$ den programmatiske og organisatoriske tradition.

\section{Problemer i reformismebestemmelsen}

Den første tese skal vise, hvorfor debatten om »reform og revolution «, som både blev og stadig bliver ført på det strategiske plan, efter min mening

ler «) opfatter jeg som en uomgængelig forudsætning for en udvikling af hypoteser. For vidste man allerede, hvordan alt skulle udforskes i detaljer, behøvede man ikke længere hypoteser. Nye spørgsmål opstår iflg. videnskabssociologiens resultater netop ved, at det gængse paradigme og den heraf satte "metodetvang", bliver gennembrudt. Dette forekommer mig især nødvendigt ved et forsøg på at udvikle en materialistisk politikteori, hvor der ud fra Marx og Engels i alle tilfælde rejser sig nogle systematiske spørgsmål. Jvf. Paul Feyerabende: Wieder den Methodenzwang, Frankfurt/M 1976; Henning/Hirsch/Reichelt/Schäfer: (red.): Karl Marx/Friedrich Engels: Staatstheorie. Materialien zur Rekonstruktion der marxistischen Staatstheorie, Frankfurt/Berlin/Wien 1974; Thomas S. Kuhn: Die Struktur wissenschaftlicher Revolutionen, Frankfurt/M 1973; Helmut Reichelt: Zur logischen Struktur des Kapitalbegriffs bei Karl Marx, Frankfurt/M 1976.

7. De politisk-sociologiske diskussioner om statsproblemet, som også mine teser er en del af, er repræsenteret i de to antologier: Rolf Ebbighausen (red.) Bürgerlicher Staat und politische Legitimation, Frankfurt/M. 1976 og Brandes, Hoffmann, Jürgens, Semmler (red.) Handbuch 5, Staat, Frankfurt/Köln 1977.

8. F. David, Der Bankrott des Reformismus, Berlin 1932. 
indeholder en ganske særlig begrænsning. Først og fremmest er det ikke muligt med udgangspunkt i de store strategidebatter, som blev udkæmpet indenfor socialdemokratiet og i II. internationale før første verdenskrig, at trække to abstrakte linier - »revolutionær « på den ene side og »revisionistisk « på den anden - op gennem historien. ${ }^{9}$ Hvor flimrende begrebet reformisme end er, så kan man vel være enig i denne sammenfattende definition:

»'Reformisme'-problemet (tematiserer) en strategisk helhedsopfattelse, hvori den statslige reformpolitik i videste forstand udgør det fornemste middel til at gennemsætte samfundsmæssige udviklingsmål. $\ll^{10}$

Med reformisme kan man således forstå såvel 1) den teoretisk underbyggede opfattelse af den skridtvise, graduelle virkeliggørelse af socialistiske målsætninger ved hjælp af parlamentarisk demokrati og mod den kapitalistiske samfundsform; som 2) forsøget på at ville repræsentere og gennemsætte de lønafhængiges elementære interesser på grundlag af $l i$ geberettigelse uden overvindelse af de kapitalistiske produktions- og ejendomsforhold. Netop i kombinationen af begge orienterings- og handlingsmuligheder modsvarede den socialdemokratiske arbejderbevægelse i Weimarrepublikken efter $1922 \mathrm{vel} » \mathrm{i}$ reneste form « dette begreb. ${ }^{11}$

9. Om denne debats historie jvf. bl.a. Kurt Brandis, Der Anfang vom Ende der Sozialdemokratie (oprindelig 1927) genoptryk Berlin 1975, Hansgeorg Conert, Die politischen Grundrichtung der deutschen Sozialdemokratie vor dem ersten Weltkrieg, Offenbach 1974, Helga Grebing, Geschichte der deutschen Arbeiterbewegung, München 1974, Groh op.cit., Bo Gustafsson, Marxismus und Revisionismus, Eduard Bernsteins Kritik des Marxismus und ihre ideengeschichtlichen Voraussetzungen, 2 bd, Frankfurt/M 1972; Detlef Lehnert, Reform und Revolution in den Strategiediskussionen der klassischen Sozialdemokratie Bonn-Bad Godesberg 1977; Erich Mathias, Kautsky und der Katskyanismus, Die Funktion der Ideologie in der deutschen Sozialdemokratie vor dem ersten Weltkrieg in: Marxismusstudien II, Tübingen 1957; Manfred Scharrer, Arbeiterbewegung und Obrigkeitsstaat, Berlin 1976; Hans-Josef Steinberg, Sozialismus und deutsche Sozialdemokratie, Bonn-Bad Godesberg 1976. I disse analyser foretages forskellige klassifikationer af »reformisme«, »revisionisme« etc., som er mindre interessante for min problemstilling, da de er klassifikationer af handlingsstrategier og - tolkninger (-ideologier). Min problemstilling suppleres (omend analysen går i en anden »retning «) af de fremstillinger, der behandler relationerne mellem ledelse og basis under den synsvinkel, at »reformismen « kan og skal tolkes som den socialdemokratiske arbejderbevægelse levevis, (f.eks. Scharrer, op.cit. jvf. her ogsåOskar Negt/A. Kluge, Öffentlichkeit und Erfahrung, Frankfurt/M 1972).

10. Lehnert, Op.cit.p. 301. Hvor problematisk det er at overføre de strategiske »tendenser « på unders $\emptyset$ gelsen af politikken inden for enkelte områder viser Adelheid von Saldern, Sozialdemokratische Kommunalpolitik in Wilhelminischer Zeit, in: K.H. Nassmacher (red.) Kommunalpolitik und Sozialdemokratie, Bonn-Bad Godesberg 1977, s. 18 ff.

11. Enheden $o g$ modsigelsesfyldtheden i de to strategiske komponenter (som allerede sås i Erfurterprogrammet) kommer i Weimarrepublikkens tid til udtryk i Heidelberger programmet 1925, jvf. Dieter Dowe/Kurt Klotzbach (red.) Programmatische Dokumente der deutschen Sozialdemokratie, Bonn-Bad Godesberg 1973, p. 203 ff. 
Reformismen - hvad enten der er tale om en teoretisk skitseret eller om en praktisk reformpolitik i de lønafhængiges interesse - der betjener sig af staten som middel, bliver nu i en polemisk drejning fortolket som modsætning til en revolutionaer eller virkelig systemoverskridende strategi. Ud fra dette kritiske udgangspunkt bliver en reformistisk strategi tilskrevet en bestemt funktion, nemlig den funktion at være systemstabiliserende via integration. Og dermed er jeg ved problemets kerne: Hvordan kan en bevægelse og/eller en strategi, som programmatisk eller faktisk udvikles ud fra modsigelsen mellem lønarbejde og kapital, være modsigelsesløs, nemlig »stabiliserende « $i$ sin systemfunktion? ${ }^{12}$

En sådan funktionsbestemmelse beror på en naiv handlingslogik, som overhovedet kun kan fastholdes inden for rammerne af teoretiske strategidebatter. Men på dette plan kan man jo ikke afgøre eller ophæve den evige strid om formidlingen mellem reform og revolution. Hertil tre bemærkninger:

1. Reformismen bliver i denne kontekst kun tolket udfra logikken i kollektive handlinger. Men kollektiv handlen er jo altid bundet ind i samfundets systemrelationer. I den traditionelle reformismekritik fremtræder samfundet i dette tilfælde blandt de kategorier, der på den ene side er angiveligt eksakt bestemmelige »objektive forudsætninger«, og på den anden side »objektive virkninger «. Men selve handlingen synes principiel udskillelig, synes mulig at strukturere i sig selv, og følgelig synes den også at være umiddelbar modificerbar alt efter den »objektive situation «. På denne baggrund lader forkerte handlinger sig naturligvis altid tyde som fejlagtig teori, strategi, taktik, forkert organisationspolitik og -tradition eller slet og ret som tilpasning eller »forræderi «. ${ }^{13}$

2. Der forudsættes en bestemt handlingstype, som består i en naiv sammenknytning mellem mål og middel. Reformismen er så en forkert formid-

12. I det følgende står dette spørgsmål bestandig i centrum af undersøgelserne, uden at det hele tiden vil blive gentaget. Ideen om at fors $\varnothing$ ge en »funktionel « analyse af reformismen stammer fra min skepsis overfor påstanden om dennes »systemstabilisering «. Thi denne påstand må for at kunne forklare, hvorfor reformismen under en af det borgerlige samfunds svære kriser netop fungerer som modstander for de samfundsmæssige grupperinger, der vil stabilisere det bestående samfundssystem - igen gribe tilbage til relativt enkle politikbegreber (såsom magtkamp, politik udelukkende begrebet som et herredømmesystem, »den herskende klasses valg af forskellige taktikker « etc.), begreber som hverken lever op til kompleksiteten i de politiske systemer i udviklede kapitalistiske lande eller begriber modsigelsesfyldtheden i de samfundsmæssige kriseprocesser.

Jvf. hertil også Niels Kadritzke, Fascismus als gesellschaftliche Realität und als unrealistischer Kampfbegriff, in: Prokla 8/9, 1973, samme forf. Reformismus als Sozialfascismis in: Prokla 11/12, 1974.

13. Eksemplarisk er Hannes Heer, Burgfrieden oder Klassenkampf, Neuwied und Berlin 1971. 
ling (eller slet ingen) mellem det socialistiske mål og vejen derhen. Det er ikke længere muligt i reformismens strategi, at erkende sammenhængen med det tilstræbte mål, og det afgørende moment, nemlig kampen om den politiske magt, stryges fra dens teori eller praksis og den borgerlige stat begribes som middel i en fredelig, graduel og evolutionær udvikling.

Begge momenter skulle føre til, at reformismen - bevidst eller ubevidst altid har haft og stadig har den »funktion« at være systemstabiliserende. Omvendt bliver det påstået, at det er muligt helt igennem målrettet at organisere kollektiv handlen inden for de samfundsmæssige systemrelationer. ${ }^{14}$ Denne forestilling er igen kun logisk under to teoretiske forudsætninger:

a) det kapitalistiske samfund udvikler sig hen mod sin afslutning trods fasevise opgange efter kriser;

b) arbejderbevægelsens opgave kan derfor kun bestå i, over for alle tilbageslag at organisere klassekampen hen imod en totalsamfundsmæssig $\gg$ afgørelse $\ll .{ }^{15}$

3. På basis af disse to første punkter fremkommer så vurderingen af den kollektive handlen, som er rettet mod forbedringen af arbejderklassens materielle levevilkår indenfor det borgerlige samfund. Da denne handlen aldrig vil kunne bevirke en endegyldig forandring af det kapitalistiske system, men på den anden side heller ikke bliver afvist, så skal en specifik »formidling « mellem »reform « og »revolution« sørge for, at reformerne ikke bliver til den bare tilpasning til systemet. I dette formidlingsfors $\emptyset \mathrm{g}$, som det efter min mening kun er muligt at udtænke indenfor strategiske skitser, bliver der - i overensstemmelse med en påstået mål-middel-relation for den politiske handlen - tvangsmæssigt abstraheret fra samtlige $u \phi n$ skede konsekvenser af handlingerne, dvs. konsekvenser, der er uforenelige med handlingernes egen logik.

14. For en kritik af denne forestilling se Niklas Luhmann, Zweckbegriff und Systemrationalität, Tübingen 1968.

15. Handlingskontinuiteten garanteres således af en quasieksterritorial instans: »Bevægelsen« eller »partiet «, begge to instanser, som repræsenterer »klassebevidstheden « som bevidsthed om samfundets totalitet og dets bevægelsesretning i form af den altid rigtige strategi. I denne grundforestilling adskiller Lenin og Luxemburg sig ikke. I en sådan sammenhæng mister kategorien »formidling « sin dialektiske kvalitet, dvs. det forhold, at den peger hen mod den samfundsmæssige totalitet og dens enhed af handlings- og systemsammenhænge, dvs. bevidste og ubevidste relationer. Det er ikke noget tilfælde, at det navnlig er i leninismen, at mekaniske begreber som f.eks. »transmission « bliver centrale. Til diskussionen om system- og handlingsteori jvf. også Jürgen Habermas/Niklas Luhmann, Theorie der Gesellschaft oder Sozialtechnologie, Frankfurt/M. 1971 og Jürgen Ritsert (red.) Gründe und Ursachen gesellschaftlichen Handelns, Frankfurt/M. 1975. 
Den strategiske abstraktion fra de handlingskonsekvenser, der er uforenelige med det revolutionære mål, fører sluttelig til en vurdering af reformer efter et enten-eller-skema. En retning af reformismekritikken argumenterer f.eks. således: Reformer er altid kun resultater af klassekampe eller præventive ydelser til dele af arbejderklassen for at integrere disse. Reformer må uden tvivl have en ambivalenskarakter: de vil kunne virke integrerende eller politiserende. Hvilke virkninger de har vil i høj grad afhænge af den måde arbejderklassen er politisk og fagforeningsmæssigt organiseret på. F.eks. bevægede Weimar-SPDs funktion sig til stadighed indenfor et spændingsfelt, der udgjordes af modsatningen mellem på den ene side opretholdelsen og effektiviseringen af den kapitalistiske samfundsorden og på den anden side de lønafhængiges sociale interesser. Resultatet af modsætningen blev inkonsekvenser i handlingerne og en fastlåsning af reformismen som formidlende bureaukrati, dvs. som det bærende lag de steder, hvor statsapparatet på den ene side og medlemmerne og organisationsfunktionærerne i SPD og fagforeningerne på den anden side sammenflettes og sammensmeltes.

I denne argumentationskæde bliver reformernes ambivalenskarakter netop ikke fremstillet, men tværtimod argumenteres der hele tiden på grundlag af samfundsmæssige antinomier, altså åbne modsætninger. Det er kun til nød organisationernes adfærd, der er ambivalent. ${ }^{16}$

Problemet vedrørende organisationerne kan naturligvis ikke blot fejes af bordet, men en kritik, der tager strategien som sit væsentligste, teoretiske udgangspunkt, må nødvendigvis altid ende med at knytte reformismeproblemet sammen med organisationerne. Dermed får de ikke fat $\mathrm{i}$ analysen af disse organisationers funktionelle indvævning i det borgerlige samfunds totalsystem og de kan altså ikke godtgøre den hævdede »systemstabilisering $\ll$.

16. Wolfgang Abendroth (Aufstieg und Krise der deutschen Sozialdemokratie. Das Problem der Zweckentfremdung einer politischen Partei durch die Anpassungstendenz von Institutionen an vorgegebene Machtverhältnisse, Frankfurt/M. 1964) har lagt grunden til denne retning i reformismekritikken. Jvf. Fülbert/Harrer op.cit. især p. 7-24. Samme forf., Kritik der sozialdemokratischen Hausgeschichtesschreibung, Köln 1975, p. 9, 19, 35. Helmut Korte (Vom Unsinn, in der SPD einen marxistischen Flügel aufbauen zu wollen in: Jungsozialisten nr. 7-9, Wunstorf 1974) tolker eksplicit reformismen som et problem om det formidlende byrokrati. Jvf. hertil også Georg Fülbert, Zur Genese des Revisionismus in der deutschen Sozialdemokratie vor 1914, in: Das Argument nr. 63, 1971. Det drejer sig her iøvrigt kun om en kritik af en bestemt argumentationsmåde, hvorved arbejdernes øvrige værdi ikke er endegyldigt bestemt. 


\section{Reformers funktionelle ambivalens eller ambivalensen i systemet til reproduktion af lønarbejdet}

Med min anden tese vil jeg forsøge, skitseagtigt, at udvikle reformers funktionelle ambivalens. Når man definerer reformer som »problemløsninger« får man følgende skridt:

1. Problemer i lønarbejdets reproduktion bliver genstand for organiserede konflikter og efterfølgende reguleringer, når disse når en bestemt grad af dysfunktionalitet for reproduktionen af det samlede system. ${ }^{17}$

2. Sådanne problemer artikuleres som interesser i sociale konflikter.

3. Bliver resultatet ikke blot en tilfældig, f.eks. repressiv, løsning, men en varig regulering, så institutionaliseres bestemte funktioner.

4. Disse skal nu på deres side formidles med allerede bestående institutionaliserede funktioner. Det kan ske over retssystemer, penge, bureaukratisk organisation eller også blot gennem ændret adfærd..$^{18}$

Et klassisk eksempel er kampen om normalarbejdsdagen og en klassisk analyse er den Marx lavede. ${ }^{19}$

Karl Marx udvikler lфnarbejde og kapital som værende en modsigelsesfuld enhed, dvs. momenter i den materielle produktionsproces, som er relateret antagonistisk til hinanden: subjektet »levende arbejde « producerer det genstandsgjorte arbejde, dvs. produktionens objekter, som samtidig bestandig bliver til kapital og dermed til herredømmesubjekt, der gør det levende arbejde til objekt. Denne antaginisme fremtræder i de sociale kampe mellem klasserne som antinomi, som en modsætning mellem to i sig selv begrundede rettigheder: ret til opretholdelse af arbejdsevnen versus ret til valorisering af kapitalen. I denne modsætning bestemmer - med Marx' formulering - magten, og i tilfældet med arbejdsdagen til sidst statsmagten

17. Om kategorien: det samfundsmæssige problem jvf. Dieter Sauer, Staat und Staatsapparat. Ein teoretischer Ansatz, Frankfurt/M 1978, p. 69 ff.

18. Muligheden for at identificere samfundsmæssige problemer, som bliver løst gennem institutionaliserede funktioner (strukturer), er det videnskabslogisk helt centrale spørgsmål for enhver systematisk samfundsteori (jvf. Günter Schmid, Funktionsanalyse und politische Theorie, Düsseldorf 1974, Manfred Deutschmann, Das Elend systemteoretischer Krisenanalyse, in: Prokla nr. 24, 1976). Efter min opfattelse kan faren for en ren tautologisk forklaring (det som eksisterer, er funktionelt) kun undgås gennem historiske »længdesnitsanalyser «, som er rettet mod sådanne problemløsningers funktionelle ambivalens og derfor samtidig kan forklare, hvorfor såvel en bestemt problemløsning på langt sigt kunne blive institutionaliseret, som hvilke problemer den ikke løser, og det betyder igen, hvorfor problemløsningerne må forandres historisk. Jvf. bl.a. Thomas Blanke. Das Dilemma der Verfassungspolitischen Diskussion der Linken, in: H. Rottleuthner (red.) Probleme der marxistischen Rechtstheorie, Frankfurt/M. 1975, s. 419 ff.

19. Karl Marx, Das Kapital, bd. 1 kapitel 8, MEW bd. 23 pp. 245-320. 
per lov. Marx undersøger derefter på hvilken måde denne lov er funktionel ambivalent: Den beskytter lønarbejdet, men befordrer imidlertid samtidig overgangen til den relative merværdiproduktion, dvs. til forøgelse af arbejdets produktivitet, til forøget udbytning af arbejdskraften, til udvidelse af den akkumulerbare merværdi. Den åbner samtidig for chancen for, at lønarbejdet får en højere andel af det producerede nyprodukt ved en passende organisering af kampen om delingsforholdet mellem løn og merværdi. På dette næste trin optræder altså igen antinomien mellem to rettigheder. Her afgør »magten « igen kampen, også her følger en retlig regulering, nemlig f.eks. anerkendelsen af arbejderorganisationerne og kollektive arbejdskontrakter. Og også disse er igen funktionelt ambivalente, for så vidt de tillader kapitalen stabile omkostningsberegninger, men dog samtidig beskytter lønarbejdet mod vilkårligt løntrykkeri.

De sociale kampe trækker et ophobet produkt af konfliktreguleringer efter sig. Disse ophobede summer af reguleringer kræver på deres side, at lønarbejdets organisationer fortløbende må bekymre sig om deres overholdelse, og ikke - abstrakt talt - overlade denne til »staten«. Thi eller ville der jo bestå den fare, at sådanne reguleringers funktionelle ambivalens ville virke imod dem på grund af den herskende magtstruktur, og endda uden at det umiddelbart blev synligt i sociale kampe. Ved siden af den antinomiske sociale kamp optræder dermed problemet om at værne om de tilkæmpede positioner i rettens form, dvs. som retstolkninger og retstvister, altså den permanente konflikt om, i hvilken interesseretning forskellige funktionelt ambivalente reguleringer skal virke.

Bragt på kort formel:

1. Konfliktreguleringens funktionelle ambivalens betyder følgelig: Reguleringen relaterer sig til modsigelsesfulde problemkonstellationer. I processen, hvor funktionen opfyldes, er reguleringen bundet til disse modsigelsers bevægelse, men udtrykker imidlertid $i k k e$ selv disse modsigelser umiddelbart. Disse fremtræder snarere som »konflikter om konfliktreguleringen «, for så vidt som sådanne reguleringer bliver knyttet sammen med andre reguleringer indenfor systemsammenhængen og dermed formidlet med andre problemer. Problemrelateringen betegner det genetiske aspekt ved konfliktreguleringen, system-relateringen betegner det i sncevrere forstand »funktionelle« aspekt ved relationerne indenfor et system.

2. Den fortsatte institutionalisering af sådanne problemløsninger/- konfliktreguleringer fremtvinger en komplementaer organisering, en komplementær vækst i lønarbejdets organisation og dets konflikt, kooperation og institutionelle sammenfletning med systemets andre organiserede bærere (først og fremmest kapitalistiske foretagender, 
organisationer og staten). Det drejer sig her ikke om en fuldstandig institutionalisering, i dette tilfælde af lønarbejdets organisationer, men om »politiksammenfletning . $^{20}$

Ud fra en sammenfatning af den hidtidige diskussion kan man tale om et system af konfliktreguleringer, hvor systemkarakteren foreløbig kun består $\mathrm{i}$, at de forskellige konfliktreguleringer står i samfundsspecifikke relationer til hinanden; relationer hvis »logik « indholdsmassigt endnu står tilbage at udvikle. I tilslutning til Marx, som i forbindelse med kampen om normalarbejdsdagen taler om »princippets sejr«, om sejr for »arbejdets $\emptyset$ konomi over besiddelsens $\emptyset$ konomi $«$, og andre steder om »arbejderklassens politiske $\varnothing \mathrm{konomi} \ll^{21}$, vil jeg tale om et system til reproduktion af l $\phi n-$ arbejdet, et system, som danner sig inden for det borgerlige samfund og som formidler politik og økonomi for lønarbejdet på en specifik måde. ${ }^{22}$

Et sådant system opstår imidlertid ikke tilfceldigt. På grund af den forudsatte adskillelse og selvstændiggjorte relation mellem politik og $\varnothing$ konomi i det borgerlige samfund retter funktionerne sig

1. фkonomisk, dvs. relateret til den materielle reproduktionsproces, mod:

- forholdet mellem lønarbejde og kapital i kampen om arbejdsbetingelserne og arbejdslønnen. Een udviklet organisationsstruktur er den kollektive arbejdsret;

- herredømmeforholdet i virksomhederne, f.eks. samarbejdsudvalgsaftalerne;

- arbejdskraftens reproduktionsområde i bredere forstand, altså sociallovgivning: f.eks. arbejdsløshed; sundhed; alderdom;

20. Dette begreb er blevet udviklet i den politikvidenskabelige føderalismeforskning. Jvf. Fritz Scharpf m.fl., Politikverflechtung: Theorie und Empirie des Kooperativen Föderalismus in der Bundesrepublik, Kronberg 1976.

21. Karl Marx, Inauguraladresse der internationalen Arbeiter-Assoziation (1864) in: MEW bd. 16 p. 5-13. Se også Lohn, Preis und Profit (1865) samme sted p. 147, og Instruktionen für die Deligierten des provisorischen Zentralrats zu den einzelnen Fragen (1867) samme sted. P. 194 ff.

22. »Princippets sejr « er så vidt jeg ved netop fra marxistisk side analytisk ikke blevet fulgt yderligere op - det har man overladt til »reformismen«. Karl Korsch har i sin bog Arbeitsrecht für Betriebsräte, (1922, nyudgivet af E. Gerlach, Frankfurt/M. 1968) gjort et af de få forsøg på at rekonstruere dette system. Den diskussion, som i de seneste år først og fremmest blandt kritiske arbejdsretsteoretikere har sigtet på at rekonstruere dette system, har knyttet an til dette værk og til andre arbejder om Weimarrepublikkens arbejdsret (Neumann, Fraenkel, KahnFreund, Sinzheimer). Jeg trækker på denne diskussion, jvf. f.eks. Blanke/Erd/Mückenberger/Stascheit (red.), Kollektives Arbeitsrecht. Quellentexte zur Geschichte das Arbeitsrechts in Deutschland, 2 Bd. Reinbeck 1975, og den fortløbende diskussion i tidsskriftet Kritische Justiz. 
- socialpolitik i snævrere forstand; bærere er her enkelte grene af den statslige forvaltning;

- arbejdskraftens kvalifikation, altså forskellige former for skolevæsen.

2. Politiske funktioner, dvs. funktioner bestemt i forhold til staten som almen herredømmeinstans, relaterer sig til:

- den enkelte lønarbejders forhold som statsborger i forhold til statsmagten (valgret og andre frihedsrettigheder);

- lønarbejdets organisationers rettigheder overfor statsmagten (anerkendelse af foreninger og partier);

- organisationernes mulige indflydelse på statsmagten (fra parlamentsindflydelse til besættelse af stillinger i alle dele af det statslige bureaukrati.)

Disse funktioner omfatter ikke lønarbejdets samlede reproduktionsområde, altså totaliteten af leveviklår. ${ }^{23} \mathrm{Og}$ den historiske gennemsættelse af funktionerne følger heller ikke denne nærmest definitoriske logik. De opstår ikke til stadighed, men snarere i ryk. Sådanne funktioner kan også opstå usamtidigt, som eksemplet Tyskland viser, hvor f.eks. socialforsikringen blev institutionaliseret af staten, før de demokratiske rettigheder var blevet virkeliggjort i fuldt omfang.

Den integrationskraft, som reformismen tilskrives, skyldes følgelig den kendsgerning, at denne politiktype altid er bærer af sådanne funktioners opståen og institutionalisering. Dvs. på den ene side skyldes den systemstabiliserende kvalitet, som reformismen tilskrives, det borgerlige samfunds evne til bestandig på ny at frembringe sådanne funktioner til reproduktion af lønarbejdet. Hvis man imidlertid ikke ganske vil prisgive den kritiske impuls i reformismebegrebet, som er rettet mod organisationerne og deres handlinger, og følge en quasideterministisk systemlogik, så må man lægge hovedvægten på spørgsmålet om granserne for et sådant system og på institutionaliseringens form. Først da kan problemet om en »systemstabilisering « afklares nærmere.

En betydelig del af reformismekritikken fra venstre består i, at påvise almene granser ${ }^{24}$ for udviklingen af systemet til reproduktion af lønarbejdet indenfor det borgerlige samfund. Hvor plausible de velfunderede kri-

23. Her kommer de unders $\varnothing$ gelser ind, som unders $\varnothing$ ger såvel arbejderklassens ikkeorganiserede grupperinger, dens levevis og forestillinger som overgangene mellem organisation og ikkeorganisation. For en begrebsliggørelse jvf. Negt og Kluge op.cit.

24. Wolfgang Müller/Christel Neusüss, Die Sozialstaatsillusion und der Widerspruch von Lohnarbeit und Kapital, in: Prokla Sonderheft 1, 1971, Willi Semmler/Jürgen Hoffmann, Kapitalakkumulation, Staatseingriffe und Lohnbewegung, in: Prokla nr. 2, 1972. 
tikker af f.eks. omfordelingsillusionen end er, så løser de dog ikke spørgsmålet om, hvordan disse grænser har kunnet lægge sig fast.

\section{Systemgrænser og aktivitetsgrænser}

Hermed kommer jeg til den tredie tese. Mens jeg i den anden tese har skitseret funktionerne i et system til reproduktion af lønarbejdet genetisk, dvs. som afhaengige af det borgerlige samfunds problemkonstellationer, så er det et andet funktionsbegreb, der står i centrum i den tredie tese. Det drejer sig her om de interne funktionelle sammenføjninger indenfor rammen af det borgerlige samfunds politiske system (som en specifik form for formidling mellem $» \varnothing k o n o m i \ll ~ o g ~ » p o l i t i k \ll) .{ }^{25}$

Under den betingelse, at det borgerlige samfund ikke ændrer sig i sine grundlæggende formationsstrukturer, er der trukket almene grænser for den statslige handlen. Disse grænser har vi kaldt systemgraenser. De kan igen differentieres: I videste forstand begrænser privatejendommen den statslige handlen. Men privatejendommen selv er i lige så høj grad en almen ret, der også beskytter lønarbejdet, som den er udtryk for den sarlige garanti for kapitalakkumulationens autonomi. Grænserne for indgreb i privatejendommen er altså fleksible, og statsinterventioner finder først deres formations-specifikke begrænsninger, når kapitalens autonomi i rådigheden over den materielle produktion er truet på afgørende måde. Anderledes udtrykt: kapitalakkumulationen er strukturelt priviligeret $\mathrm{i}$ forholdet politik/økonomi. ${ }^{26}$

Udsagnene om almene grænser definerer altså for det første endnu ikke mulighederne for al statslig handlen, først og fremmest ikke dennes organisationsform. Teoretisk kan der tænkes en ligefrem uendelig mængde af aktiviteter, og empirisk er det borgerlige samfunds politiske system som helhed blevet et enormt kompleks. For det andet er de almene grænser ikke mure, og grænsekrænkelser kan ikke forstås efter modellen for brud på husfreden - de er snarere funktionsforstyrrelser. I den samfundsmæssige proces er overholdelsen og håndhævelsen af disse grænser bestandig

25. Niklas Luhmanns, Soziologie des politischen Systems, in: sammes Soziologische Aufklärung. Aufsätze zur Theorie sozialer Systeme, bd. 1, Opladen 1970, kan tjene som ledetråd i skitseringen af et abstrakt udkast til sådanne funktionelle sammenføjninger.

26. Om den statsteoretiske begrebsdannelse, der ligger til grund for min undersøgelse her, jvf. Blanke/Jürgens/Kastendiek, Kritik der politischen Wissenschaft 2 bd. Frankfurt/M. 1975, Bernhard Blanke, Formen und Formwandel des politischen Systems in der bürgerlichen Gesellschaft, in: Handbuch 5 Staat op.cit. og Blanke/Jürgens/Kastendiek, Systemgrenze des Staates - Grenze der Theoriediskussion? in: Die neue Gesellschaft, nr. 81975. 
et problem i de samfundsmæssige konflikter. I øvrigt står de til debat ved enhver institutionalisering af statslige aktivitetsområder i spørgsmålet om institutionaliseringens form. Dette problem har vi betegnet med termen aktivitetsgraense (Tätigkeitsgrenze). Relateret til systemet til reproduktion af lønarbejdet betyder denne opfattelse, at på de forskellige niveauer af det politisk- $\varnothing$ konomiske funktionsområde, som opstår i sociale konflikter og deres regulering, er de grænser, der er trukket for de respektive kontrahenter, forskellige. Systemet til reproduktion af lønarbejdet er, opfattet sådan, et i sig selv differentieret system. Der ligger ikke nogen samlet, ensartet plan til grund for dets udvikling ${ }^{27}$, uanset at netop reformistiske strategiudkast bestandig forsøger at give systemet en sådan logik (tænk f.eks. på begrebet $\varnothing$ konomisk demokrati $)^{28}$. Vi skelner mellem to typer af aktivitetsgrænser:

a) en grundkonstellation, som er relativ stabil for bestemte udviklingsetaper over længere tid, f.eks. forholdet mellem lønarbejde og kapital, således som det blev og er fastlagt med den endegyldige anerkendelse af fagforeningerne og den kollektive arbejdsret;

b) kompromis- og fordelingsstrukturer for materielle ressourcer og politisk indflydelse, som etableres indenfor denne grundkonstellation.

De til enhver tid værende, aktuelle konflikt- og kompromisstrukturer opretholder den mere langsigtede etablerede grundkonstellation, men forskyder den som tendens. Denne forskydning stopper dog ved den almene grænse og reproducerer den - forudsat det ikke er lykkedes for nogen af siderne at gøre betydelige »erobringer«. I tendensanalysen formidles proces og struktur. Hvorvidt langsigtede evolutioner af samfundssystemet sætter sig igennem i en sådan tendens, er det mest omstridte

27. I planlægningsteoriens kategorier ville man sige, at systemet var opstået »imkrementalt « dvs. gennem jævn partiel vækst. Netop i krisen beklager man, at ingen mere kan gennemskue det sammenfiltrede socialpolitiske vildnis. Det hjælper ikke meget at fors $\varnothing$ ge at sammenstille og systematisere det retlige grundlag i f.eks. socialrets-eller arbejdsretsfremstillinger, fordi man her ikke fatter de funktionelle sammenhænge, men snarere tildækker det problem, de står overfor: at organisere modsigelsesfulde funktioner. Den »inkrementale« måde, hvorpå systemet til reproduktion af lønarbejdet er opstået (sammen med den delvis »ulogiske« organisationsform) gør det netop svært for lønarbejdets organisationer, at optræde planmæssigt i deres konkrete politik, hvilket altid fordres af dere venstrefløjskritikere. De hinker snarere bagefter udviklingen. Det som er gældende for funktionernes opståen, gælder iøvrigt også for deres afvikling; den følger ligeledes inkrementalt. Før den indre logik i denne afvikling er gennemskuelig, er ophobningen af et bestemt »kritisk « konfliktpotentiale dog nødvendigt. Herom mere nedenfor.

28. Jvf. Cora Stephans bidrag: Wirtschaftsdemokratie und Umbau der Wirtschaft, in: W. Luthardt (red.),. Sozialdemokratische Arbeiterbewegung und Weimarer Republik. Materialien zur gesellschaftlichen Entwicklung 1927-1933, 2. bind. Frankfurt/M. 1978. 
spørgsmål ikke blot i samfundsvidenskaberne, men også i historievidenskaben. Mine overvejelser ligger på en vis måde på et niveau under disse spørgsmål. Det, der interesserer mig, er følgende problem: Er der tærskler for forandringer af de samfundsmæssige relationer, som tvangsmæssigt indicerer funktionsforstyrrelser (kriser)? Hvilken rolle spiller det politiske system, som funktionelt er bundet til grundbetingelserne, $\mathrm{i}$ en sådan forandringsproces? Hvilke forandringer ville være nødvendige i de samfundsmæssige styrkekonstellationer for at løsne sådanne funktionelle bindinger?

Den rolle, som den konkrete form for institutionalisering - f.eks. af de »sociale statsfunktioner « - spiller, bliver nu tydelig: Det er afgørende for aktionsspillerummet såvel som for muligheden for at erkende de samfundsmæssige udviklingstendenser, hvorvidt den funktionelle ambivalens kan udtrykke sig. Sagt anderledes: Netop for arbejderbevægelsen er det i forbindelse med de almene restriktioner for staten i det borgerlige samfund vigtigt, om arbejderbevægelsen gennem institutionaliseringen af systemet til reproduktion af lønarbejdet bliver koblet til de immanente udviklingstendenser og grænser i dette samfund, eller om den i krisetider kan artikulere de sociale konflikter autonomt. ${ }^{29}$

Til spørgsmålet om institutionaliseringens form vil jeg med tre eksempler, som viser typologiscringer af den tyske udvikling, vise, hvordan »den $\emptyset$ konomiske politiks primat« kan sætte sig igennem.

29. Dette problem er blevet diskuteret under overskriften reformismens »statsfixering «. Men herved overbetones den »ideologiske« statsfixering og dens materielle grundlag bliver ikke tilstrækkeligt unders $\emptyset$ gt (jvf. især Bodo Zeuner, »Solidarität mit der SPD oder Solidarität mit der Klasse? Zur SPD-bindung der DGB, in: Prokla nr. 26, 1976). Metodisk stammer denne begrænsning fra, at de »sociale funktioner « tilskrives staten. Derved bliver på den anden side - logisk - arbejderbevægelsen en principelt autonom kraft, hvis autonomi alene kan stilles til diskussion p.gr.a. organisationernes ageren. Dette kan eksemplarisk eftervises hos Johannes Agnoli, hos hvem »Staten « på den ene side organiserer arbejderklassens reproduktion, mens klassen på den anden side forbliver ikke-integreret, og hvor endelig de »retliggjorte fagforeninger « og de »statsliggjorte partier« svæver derimellem. At organisationerne netop er blevet til »forvaltere « af de sociale funktioner, overses, hvorved deres funktionelle ambivalens forsvinder og til nød kun kan udtrykke sig igen $i$ et andet forhold mellem basis og organisationer. Her bliver betydningen af det tidligere skitserede handlingsbegreb klar: Politik og $\varnothing$ konomi bliver abstrakt adskilt i forhold til arbejderbevægelsen; »politik « konstitueres for arbejderbevægelsen som autonom handlingssfære, mens $\varnothing$ konomi bliver sammensat som »Stat«og »kapital«. Heri adskiller Stamokap-teorien og mange »udogmatiske « statsteorier sig overhovedet ikke fra hinanden. (Jvf. Johannes Agnoli, Überlegungen zum bürgerlichen Staat, Berlin 1975, først og fremmest kapitlet: Klasse und Staat, p. $60 \mathrm{ff}$.) 
1. Store dele af systemet til reproduktion af lønarbejdet er organiseret gennem den kollektive arbejdsret. Dennes grundstruktur ${ }^{30}$ beror på en vidt gående autonomi for klasseorganisationerne og på inddragelse af statsmagten som garanten for den i retlige former organiserede klassekonflikt. Det såvel aktuelle som periodiske konfliktpotentiale i dette område er her relativt åbenbart. Her antager den antagonistiske konflikt antinomiens form, modsætningen: ret mod ret. Alligevel viser netop diskussionerne om arbejdsretten under stikordet »retliggørelse«, at en bestemt fortolkning af arbejdsrettens funktion, som er retlig gennemsat og accepteret af organisationerne, og som f.eks. hviler på »fredspligt« og på »social konsensus«, kan fratage dette område dets konfliktkvalitet over kortere eller længere tidsrum uden at $\varnothing$ delægge den funktionelle ambivalens.

2. Et andet område af lønarbejdets reproduktion er i Tyskland organiseret efter forsikringsprincippet. ${ }^{31}$ Åbenbart på grund af, at staten indførte dette princip i kejserriget, henregnes området (f.eks. også i finansvidenskaben) under »staten«, skønt det funktionelt regulerer et problem i den materielle reproduktion, altså i økonomien. Den halvstatslige organisation af forsikringen, bag hvis form der skjuler sig et princip om selvforvaltning efter det delvis »ulogiske « paritetsprincip (hvorfor er arbejdsgiverne f.eks. medbestemmende i arbejdsløshedsforsikringen, når indbetalingerne udelukkende er en del af lønnen?), frembyder nu en specifik mulighed for, at systemet til reproduktion af lønarbejdet kan bindes til den kapitalistiske $\varnothing$ konomis bevægelser. Akkumulationsprocessen og dens virkninger på lønnen slår igennem på bidragene (og på statstilskud eller-garantier, som må financieres over skatterne). Men det, at forsikringssystemet hviler på den individuelle »ydelse« (og dermed på betragtelige interne differentieringer og sarstillinger blandt lønarbejderne som klasse) får i udpræget grad dets formationsspecifikke genese og begrænsning til at forsvinde. Her står ikke længere ret mod ret som klassemodsætningernes form, men

30. Jvf. Blanke/Erd/Mückenberg/Stacheit, Kollektives Arbeitsrecht, op.cit., Hans-Hermann Hartwich, Arbeitsmarkt, Verbände und Staat 1918-33, Berlin 1967, Thilo Ramm (Red.) Arbeitsrecht und Politik, Quellentexte 1918-33, Neuwied und Berlin 1966, Hugo Sinzheimer, Arbeitsrecht und Rechtssoziologie, 2 bd. Frankfurt/Köln 1976.

31. Monika Fuhrke, Staatliche Sozialpolitik, Eine Untersuchung zur Entwicklung des Systems der sozialen Sicherheit im Kapitalismus. Offenbach 1975, Ludwig Preller, Sozialpolitik in der Weimarer Republik, Stuttgart 1949. Det store skub til en gennemsættelse af den statlige organisering af disse sociale funktioner skete endegyldigt i Weimarrepublikken, specielt i tiden omkring socialreformen 1926/27 (AVAVG, Lov om arbejdsformidling og arbejdsløshedsforsikring). At fagforeningerne i kejserriget allerede havde set problemet med en sådan »statsligg ørelse « viser A. v. Saldern eksemplarisk i: Emanzipations- und Integrationsprozesse im kulturellen und sozialen Bereich, in: IWK 1977, Heft 4 især p. 495 ff. 
først og fremmest lønarbejdernes individuelle retskrav såvel i indbyrdes konkurrence som overfor staten. De forsikredes solidariske fællesskab er udelukkende en tom formel for fordelingen af financieringsproblemerne. Alligevel bevarer også dette efter forsikringsprincippet organiserede område sin funktionelle ambivalens. Som en del af den samfundsmæssige lønkvote står denne pengemasse, der omfordeles blandt lønarbejderklassen, arbejderne og funktionærerne, stadigvæk i en mulig modsætning til akkumulationsprocessens krav.

3. En tredie organiseringsform, nemlig den umiddelbare statslige tilvejebringelse af ydelser, socialpolitikken $i$ sncevrere forstand, har traditionelt haft forsorgens og undertrykkelsens janushoved. Den er derudover principielt koblet til den $\varnothing$ konomiske proces over skatterne. Som en del af »statskvoten « optræder dette område i krisetider regelmæssigt i debatterne om den rigtige krisepolitik. ${ }^{32}$

Disse tre områder er altså flettet tæt sammen med hinanden, selv når institutionaliseringens konkrete form med tiden lader én »glemme «, at det drejer sig om et system til reproduktion af lønarbejdet. I krisen kommer denne sammenhæng til syne i det samtidige tryk fra kapitalen, de borgerlige partier og »vismændene $\bmod » l ø$ nkvoten $«$ og $»$ statskvoten $«{ }^{33}$

Meningen med min korte fremstilling var ikke at udvikle denne sammenhæng udtømmende, men at antyde, at institutionaliseringens konkrete form er afg ørende for, hvordan den $\varnothing$ konomiske politiks forrang for socialpolitikken og (indenfor den økonomiske politik selv) kapitalakkumulationens forrang overfor lønnen kan sætte sig igennem, ikke nødvendigvis $m a ̊$ sætte sig igennem. Den funktionelle ambivalens lader sig også aflæse af, hvordan fors $\emptyset$ get på institutionaliseringen af reformer samtidig kan skabe forudsætningerne for afinstitutionaliseringen i krisen, når den

32. Derved opstår det paradox, at »statskvoten« trods faldende statsudgifter stiger, fordi $\emptyset$ konomiens skrumpningsproces forløber endnu hurtigere og staten ikke kan sænke sine sociale udgifter så hurtigt, som $\varnothing$ konomien kan producere arbejdsløse: et paradox, som prægede Brünings $\varnothing$ konomiske politik. For taloplysninger se W.G. Hoffmann/F. Grumbach/H. Hesse, Das Wachstum der deutschen Wirtschaft seit der Mitte des 19. Jahrhunderts, Berlin/Heidelberg/New York 1965, Dietmar Keese, Die volkswirtschaftliche Gesamtgrössen für das deutsche Reich in den Jahren 1925-36 in: Conze/Raupach (red.) Die Staats- und Wirtschaftskrise des Deutschen Reiches 1929/1933, Stuttgart 1967, p. 35 ff.

33. Dette viser sig under den store koalition 1928 til 1930 i konflikten i jernindustrien i Ruhr og i kampen om socialpolitikken, jvf. Helga Timm, Die deutsche Sozialpolitik und der Bruch der Grossen Koalition im März 1930, Düsseldorf 1952, Ernst Fraenkel, Der Ruhreisenstreit 1928-29 in historisch-politischer Sicht, in: sammes Reformismus und Pluralismus (red. af Falk Esche und Frank Grube) Hamburg 1973, p. 145 ff., Hartwich op.cit. (omhandler især Berlin), Michael Schneider, Unternehmer und Demokratie Bonn-Bad Godesberg 1975, (omhandler arbejdsgivernes strategi). 
totalsamfundsmæssige asymmetri vedligeholdes i dem. Kerneproblemet gemmer sig i den til enhver tid eksisterende grad af »statsliggørelse « af systemet til reproduktion af lønarbejdet. ${ }^{34}$ For reformismeproblemet må det følge heraf, at en strategi (jeg minder om Lehnerts definition, som jeg citerede i begyndelsen) som i det væsentlige koncentrerer sig om staten (det gælder alle momenter, organisatorisk såvel som ideologisk) i ligeså høj grad hviler på kapitalakkumulationens implicitte primat (grænseproblemet) som på den eksplicitte prosperitetsforventning. Hvilke konsekvenser opstår der heraf for en krisepolitik? Først og fremmest i krisesituationer, som alt $i$ alt udviser en regressiv tendens i kapitalakkumulationen og dermed sætter spørgsmålstegn ved de etablerede konfliktog kompromisstrukturer? Kan »reformismen « artikulere de fremvoksende sociale konflikter i takt med udviklingstendensen og trække en politisk- $\varnothing$ konomisk forsvarslinie, som forhindrer, at lønarbejdet bliver til det blotte objekt for krisen?

\section{Reformisme og krisepolitik}

I den afsluttende fjerde tese vil jeg gerne konkretisere de almene hypoteser i forhold til problemer i krisepolitikken og forfølge dem videre i forhold til handlingslinierne i den socialdemokratiske arbejderbevægelses politik i den $\varnothing$ konomiske verdenskrise.

Man ville gøre det for enkelt for sig selv, hvis man fraskrev weimarsocialdemokratiet enhver bevidsthed om, at det agerede indenfor rammerne af et kapitalistisk samfund. De omfangsrige statsteoretiske og økonomiteoretiske debatter, som jo alle sammen kredser om temaet, hvordan kan man forandre et kapitalistisk samfund indefra, og som først lidt efter lidt er blevet »genopdaget «, taler imod en sådan antagelse. ${ }^{35}$ Men det centrale

34. Her må man sætte ind med sammenlignede regionalstudier, som skal analysere de forskellige løsningsformer på sociale problemer især med henblik på, hvorvidt de er funktionelle aekvivalenter for de samme problemer. Som eksempel på en sådan undersøgelse kan tages Stefan Leibfried, Forord, til: Piven/Clovard, Regulierung der Armut. Die Politik der öffentlichen Wohlfart, Frankfurt/M. 1977, p. 7-67. Der burde også skitseres et sammenlignende perspektiv i relation til overgangen fra Weimarrepublikken til fascismen: hvilke funktioner var fascismen $n \phi d t$ til at organisere i et system til reproduktion af lønarbejdet og hvilke var ikke nødvendige; var disse institutionaliseringer 'funktionelt ækvivalente' eller var de specifikt andre funktioner? Overvejelser herover findes hos Timothy W. Mason, Arbeiterklasse und Volksgemeinschaft, Opladen 1975.

35. Her skal der henvises til de forskellige antologier af Fraenkel, Heller, Kirchheimer, Sinzheimer og andre. Nogle overvejelser omkring disse statsopfattelsers »reformistiske « karakter findes hos Blanke/Jürgens/Kastendiek, Kritik der politischen Wissenschaft, op.cit. kapitel 7, 
problem for dets strategi $o g$ for dets faktiske sammenfletning med det bestående samfund var, at det hele beroede på to forudsætninger - især umiddelbart før verdenskrisens udbrud, hvor den socialdemokratiske arbejderbevægelse kunne fremvise noget i retning af en samlet strategi $(1927 / 28)$ : de sammenhængende forestillinger om den »organiserede kapitalisme « og $» \varnothing$ konomisk demokrati . De to forudsætninger var:

1. en kapitalisme, der på grund af indre organiseringsprocesser i fremtiden ville kunne reproduceres krisefrit.

2. socialdemokratiets mulige rådighed over den parlamentariske stat gennem udvidelse af organisationen og vælgerbasis eller gennem koalitioner eller indflydelse på statsbureaukratiet.

I kritikken af disse vurderinger og i forventningerne til en anden politik er både kritikkerne fra venstre og de forfattere, som hælder mod socialdemokratiet, på sælsom vis enige på ét punkt: Ex post forventes en anticyklisk politiktype eller en sådan »konstrueres « som alternativ. Ved den store koalitions sammenbrud har sådanne handlingslinier antydningsvis vist sig. Denne fase er også kendetegnet derved, at den negative sammenhæng mellem det institutionaliserede system til reproduktion af lønarbejdet og kapitalakkumulationens krise blev tydelig i og med konflikterne om arbejdsløshedsforsikringen og saneringen af statsfinancerne. Men den efterfølgende tolereringspolitik er procyklisk kriseskarpende - ikke kun i $\varnothing$ konomisk-politisk sammenhæng.

$\mathrm{Nu}$ finder man ofte i litteraturen en bagudrettet sanktionering af, at socialdemokratiet accepterede »den samlede politiks « forrang for socialpolitikken. ${ }^{36}$ Samtidig konstateres socialdemokratiets manglende handlingsevne. Denne manglende handlingsevne bliver ex post »løst op« fra to sider:

1. I tesen om at socialdemokratiet konsekvent skulle have udviklet sig til et »folkeparti«; 2. i overvejelserne om ikke en keynesiansk økonomisk politik under socialdemokratiets medvirken havde kunnet lede den fascistiske stormflod bort. ${ }^{37}$

Hans Ulrich, Die Einschätzung von kapitalistischer Entwicklung und Rolle des Staates durch den Allgemeinen Deutschen Gewerkschaftsbund, in: Prokla nr. 6, 1973, Wolfgang Müller, der Pluralismus - Die Staatstheorie des Reformismus, in: Doeker/Steffani, Klassenjustiz und Pluralismus, Festschrift für Ernst Fraenkel, Hamburg 1973. Jvf. også bidraget fra Brauchmüller/Hartmann in: Wolfgang Luthard (red.) op.cit., s. $354 \mathrm{ff}$.

36. F.eks. Ursula Hüllbüsch, Die deutschen Gewerkschaften in der Weltwirtschaftskrise, in: Conze/Raupach op.cit. p. $126 \mathrm{ff}$.

37. Den første argumentationslinie findes udtalt hos Mommsen, op.cit., den anden findes hos Hüllbüsch, op.cit., Michael Schneider, Das Arbeitsbeschaffungsprogramm des ADGB, Zur gewerkschaftlichen Politik in der Endphase der Weimarer Republik, Bonn-Bad Godesberg 1975, Gates, op.cit. I Mommsen/Petzina/Weisbrod, Industrielles System und politische 
Uden her at kunne fremstille strukturen og dybden i krisen i Tyskland 1929 til 1933 i enkeltheder vil jeg mod disse argumenter indvende:

For det første at et socialdemokrati, som havde skiftet »ham « til et folkeparti (en problematisk fordring, når man betænker, at SPD netop var et reformistisk arbejderparti, og også blev anset for at være et sådant af de andre samfundsmæssige kræfter og grupper) ikke havde kunnet lave en anden krisepolitik; krisen ville ligeledes være blevet løst på lønarbejdets bekostning, men i autoritære (evt. parlamentarisk autoritære) former. For det andet at en »demokratisk « keynesianisme kun ville have en chance for at gennemføre en $\varnothing$ konomisk kriseløsning, hvis strukturproblemet ${ }^{38} \mathrm{i}$ den tyske kapitalisme var blevet løst gennem en politisk værdinedskrivning af store dele af de sværindustrielle og $\varnothing$ vrige storindustrielle kapitaler (hvilket går i mod det første argument, thi med en sådan linie ville en »folkepartipolitik« ikke have været mulig, men i det højeste en enhedsfrontpolitik). Den anden udvej var en massiv ordreudstedelse i skikkelse af rustningspolitik, som man omvendt ikke kunne forlange af SPD (man kan sammenligne de 1-2 mia RM, som fagforeningerne havde tiltænkt til arbejdspladsskabelse, med de omkring 60 mia. RM som frem til 1939 blev puttet ned i krigsproduktionen.) ${ }^{39}$

Entwicklung in der Weimarer Republik, op.cit. er der kun få bidrag om kriseudviklingen og dens virkninger på arbejderbevægelsen; øjensynlig reproduceres også i forskningen »sozialpolitikkens « underordning under den samlede politik.

38. De fleste unders $\emptyset$ gelser af den $\emptyset$ konomiske krise er netop set $u d$ fra dette aspekt ubrugelige, fordi de indskrænker sig til en kronologisk opstilling af statistiske »tildragelser«, hvorved de forskellige faktorer i krisen (agrarkrise, pengekrise, valutakrise, karteller osv.) blot bliver adderet. Således f.eks. Charles P. Kindleberger, Die Weltwirtschaftskrise, München 1973. Keynesianismens »strukturdeficit « (se herom Michael Bolle, Globalsteuerung und ökonomische Krise, in: Handbuch 5, Staat, op.cit., Venstrekeynesianismen (Christoph Deutschmann, Der linke Keynesianismus, Frankfurt/M. 1973) præger også Keeses arbejde, op.cit. SohnRethels analyse forekommer mig stadig den mest plausible. Den er - om end på baggrund af andre samfundsteoretiske præmisser - blevet bekræftet af analyserne af Mottek/Becker/ Schröder, Wirtschaftsgeschichte Deutschlands, Bd. 3, Berlin (DDR) 1975 og Dieter Petzina, Grundriss der deutschen Wirtschaftsgeschichte 1918-45, in: Deutsche Geschichte seit dem 1. Weltkrieg, bd. 2 Stuttgart 1971 f. - Iøvrigt kan krisen kun undersøges i sin kontinuitet ind i anden verdenskrig. Om kontinuitetsproblemet jvf. Eike Hennig, Thesen zur deutschen Sozialund Wirtschaftsgeschichte 1933 bis 1938, Frankfurt/M. 1973, Gerd Hardach, Deutschland in der Weltwirtschaft 1870-1970, Frankfurt/M. 1977, Niels Kadritzke, Fascismus und Krise, Frankfurt/M. 1976.

39. Omkring arbejdspladsskabelsen se bidraget af Michael Schneider in: W. Luthardt, op.cit. - I rustningsudgifternes højde kommer følgelig ikke kun den politiske beslutning til udtryk, men også en nødvendighed sat af den økonomiske struktur, som ikke tillod en anden form for »fuldbeskæftigelsespolitik «på basis af den eksisterende $\emptyset$ konomi. Dette overser f.eks. René Erbe, Die nationalsozialistische Wirtschaftspolitik 1933-39 im Lichte der modernen Theorie, Zürich 1958. De andre kapitalistiske lande kunne også først virkelig overvinde krisen i 
Det betyder: Sådanne bagudrettet, konstruerede strategiske alternativer, som ex post blot sanktionerer, at socialdemokratiet for at redde »demokratiet « mod »totalitarismen « ikke som den centrale strategiske ledetråd havde stræbt efter arbejderklassens enhed, bliver teoretisk fanget i de samme tvangsmekanismer, som historisk har betinget den socialdemokratiske arbejderbevægelses manglende handlingsevne. For det var netop den »samlede politiks « primat over socialpolitikken, der førte til en slags selvopløsning af den socialdemokratiske politik.

Jeg vil forsøge at udvikle denne linie i selvopløsningen som et resultat af systemiske tvangsmekanismer. Dvs. jeg skildrer godt nok handlingslinierne, kritiserer dem imidlertid ikke i handlingslogikken, men fremstiller disse »handlinger « som strukturelt betinget, hvor den faktisk førte politik tages som forudsætning. ${ }^{40}$

Kriseudviklingens totalsamfundsmæssige tendens fra 1928-33 lader sig skitsere nogenlunde således:

1. Set fra kapitalsiden er den strategiske retning klar fra i hvert tilfælde 1930: befrielse af kapitalakkumulationen fra den angiveligt allerede oprettede »socialisme «. For arbejdsgiverne er reformismens ambivalens tydelig - socialdemokratiet bliver til stadighed også betragtet som potentiel organisator af klassekonflikterne. Kapitalen har to fordele i krisen: Den besidder for det første informationerne om krisens dybde, selvom det videre $\varnothing$ konomiske kriseforl $\varnothing \mathrm{b}$ ikke er tydeligt. For det andet

verdenskrigen, hvilket især gælder for USA og almindeligvis overses i overvejelserne over, hvorfor der ikke fandtes nogen fascisme der. Fascismeproblemet kan ikke stilles i den form, at USA havde overvundet den $\phi$ konomiske krise gennem en keynesiansk politik, men snarere på den måde, at det amerikanske samfund havde fundet andre politiske former til krisebearbejdningen. Disse lå væsentligst deri, at den amerikanske arbejderklasse på en ganske anden måde viste sig integrationsdygtig, hvor dog magtens rolle overfor arbejderorganisationerne (Stat og Mafia!) må undersøges nøjere. Om det sidste anstiller Maurice Dobb, Zwischen den Weltkriegen, in: Entwicklung des Kapitalismus, Köln/Berlin 1970 p. 318 ff., nogle overvejelser.

40. Her forudsætter jeg de øvrige bidrag in W. Luthardt op.cit. såvel som den dér citerede litteratur. En lignende argumentation mht. SPD's politik før 1933 er udviklet af Wolfram Wette: Mit dem Stimmzettel gegen den Faschismus? og Horst Lademacher: Gewalt der Legalität oder Legalität der Gewalt, in: W. Huber/J. Schwerdtfeger (red.): Frieden, Gewalt, Sozialismus. Stuttgart 1976, p. 358ff, 404ff. Heller ingen af disse undgår imidlertid helt faren for at lave en reformismekritik, der abstraherer fra de strukturelle problemer. Mht. forløbet i Weimarrepublikkens sidste år jvf. også Werner Conze: Die politischen Entscheidungen in Deutschland 1929-1933, in: Conze/Raupach, op.cit., p. 176 ff. (som skildrer konsekvensen af selvopløsningen, omend meget vaklende, men kun kan fatte denne med kategorien den »tiltagende sandsynlighed «, fordi han er orienteret mod en beslutningskaede); E. Mathias/R. Morsey: Das Ende der Parteien 1933, Düsseldorf 1960, og bidraget af Hans Kluge in W. Luthardt, op.cit. 
har den et negativt handlingsforspring. De nye analyser af de forskellige strategier hos de forskellige kapitalgrupper viser imidlertid samtidig, at kriseløsningens politiske form først udskilte sig i det videre forløb, og at nationalsocialisternes magtovertagelse først var produktet af en kompliceret kompromisproces mellem forskellige konservative og reaktionære kræfter. ${ }^{41}$

2. Forudsætningen herfor var for det første, at eksekutivmagten lidt efter lidt var blevet løst fra Weimarforfatningens grundsætninger og dermed fra den parlamentarisk-demokratiske kontrol. For det andet måtte lønarbejdets indflydelse alt i alt fortrænges fra det politiske system. Dette krævede forskydninger af aktivitetsgranserne i nedbrydningen af formidlingen mellem politik og økonomi, først og fremmest nedbrydningen af overenskomstsystemet og nedskæringerne af de sociale ydelser. ${ }^{42}$

3. Kapital og selvstændiggjort eksekutivmagt kunne ikke regere alene mod folkets overvældende flertal. Efter at de borgerlige partier var skrumpet ind blev nødvendigheden af en massebasis tydelig - senest med Papen-eksperimentet. Denne massebasis i skikkelse af den fascistiske bevægelse er lige så meget resultat af krisen og af samfundets desintegration. Den forbliver derfor til stadighed et ikke fuldstændigt kalkulerbart element.

4. Hvordan har nu socialdemokratiets adfærd virket i denne konstellation?

Især i Brünning-perioden krydses forskellige linier, hvis modsigelsesfyldthed systemisk producerer den beklagede, manglende handlingsevne hos den socialdemokratiske arbejderbevægelse. Med andre ord: Samfundsmæssige udviklingstendenser lader sig fra et bestemt punkt ikke længere korrigere, fordi de netop udtrykker systemprocesser, som sætter sig strukturelt igennem, når de en gang er sat i bevægelse. (Hvis ikke dette var tilfældet, ville ordet »krise« være galt anbragt).

a) Den socialdemokratiske arbejderbevægelses angst for massebevægelser og ikke-parlamentariske kampformer (allerede i 1918/19 en årsag til nederlaget) og det primat, man tilskriver opretholdelsen af de etablerede, institutionaliserede indflydelsesmuligheder, tvinger denne bevægelse ind $\mathrm{i}$ en tolereringsstrategi for at sikre »institutionsopretholdelsen «, selv når prisen er forfatningens praktiske udhuling. ${ }^{43}$

41. Sohn-Rethel, op.cit., Dirk Stegmann: Kapitalismus und Faschismus in Deutschland 19291934, in: Gesellschaft. Beiträge zur Marxschen Theorie 6, Frankfurt/M 1976, p. $19 \mathrm{ff}$.

42. Smlg. Rossmarie Leuschen-Seppels bidrag in: W. Luthardt op.cit.

43. Dette havde venstresocialister inden for og i udkanten af Socialdemokratiet allerede erkendt dengang, jvf. Ulrich Heinemanns bidrag in: W. Luthardt op.cit., såvel som de samtidige 
b) Denne politik beror på en manglende evne til at analysere den $m u$ lige forening af forskelligartede og konkurrerende interessegrupper, partier og magtbærere fra midten ud til højre. ${ }^{44}$ Det bliver især tydeligt mod Weimarrepublikkens afslutning, da socialdemokratiet undervurderer en forbindelse mellem konservative grupperinger og den fascistiske massebevagelse.

c) Det, der viser sig på den parlamentariske scene, har sit materielle fundament i systemet til reproduktion af lønarbejdet: overenskomstsystemet, arbejdsløshedsforsikringen osv. Med dette system var den socialdemokratiske arbejderbevægelse placeret som et hjul i maskineriet og den havde komplementcert hertil organiseret sig bureaukratisk. ${ }^{45}$ Det som generelt tematiseres som bureaukratiets uhåndterlighed (f.eks. hos Mommsen), får kun samfundsteoretisk mening, hvos man analyserer det materielle fundament for »politiksammenfletningen $\ll$.

d) Da opretholdelsen af status-quo også for socialdemokratiet i stadig højere grad bliver det fremmeste, strategiske primat, tolererer det skridtvis den materielle nedbrydning af de sociale statsfunktioner (Brünnings nødforordninger) for så vidt systemet i det mindste formelt opretholdes i dets grundtræk. Mens Hilferding i sin berømte tale på Kielerpartikongressen i

Arkadij Gurland: Das Heute der proletarischen Aktion, Berlin 1931; og Otto Kirchheimer: Von der Weimarer Republik zum Faschismus (artikler), Frankfurt/M. 1976.

44. Jvf. Brauchmüller/Hartmann og Helga Grebing in: W. Luthardt, op.cit.

45. Hartwich, op.cit., viser dette med eksemplet om samarbejdet mellem alle fagforeningerne indbyrdes og med rigsarbejdsministeriet (såvel centralt som i voldgiftsapparatet). Ernst Fraenkels(1929) og Franz Neumanns (1942) vurdering af det »kollektive demokrati« er interessant. Fraenkel går stadigvæk helt igennem positivt ud fra, at der i Weimar skulle være opstået en ny type demokrati, i hvilken »organisationerne får overdraget en umiddelbar indflydelse på dannelsen af statsviljen, realiseringen af statsmagten (...) I og med, at de nødvendigvis bureaukratisk udviklede økonomiske organisationer (ergo også fagforeningerne) bliver indlemmet i statens bureaukratiske apparat i kraft af egen ret, kan funktionærerne i organisationerne, der er udstyret med kollektivt demokrati, finde den støtte over for de statslige embedsmænd, der forhindrer, at lægmandselementet i forvaltningen og justitsen bliver betragtet som dekoration på statsmaskineriet«. (Kollektive Demokratie, in: E. Fraenkel: Reformismus und Pluralismus, op.cit. p. 73 ff.) Omvendt gør Neumann 1942 i sin fascismeanalyse(Behemoth. Struktur und Praxis des Nationalsozialismus, udg. af G. Schäfer, Frankfurt/M. 1977, især siderne 467-477) netop det kollektive demokrati ansvarlig for, at den socialdemokratiske arbejderbevægelse var ude af stand til at handle i krisen: Fagforeninger og politiske partier var »blevet (til) bureaukratiske apparater, der var bundet til staten ved talløse bånd (...) Således tæt forbundet med det bestående system og ovenikøbet fuldstændigt bureaukratiseret, mister fagforeningerne og Socialdemokratiet deres handlefrihed «. Neumann anfører også detallieret de etablerede funktioner (overenskomst-systemet, arbejdsløshedsforsikring, arbejdsret etc.). R.N. Hunt (German Social Democracy 1918-1933, New Haven/London 1964) kommer ganske vist med en mængde data om bureaukratiseringen i SPD, men er kun lidet oplysende for en funktionel forklaring. 
1927 havde talt om »demokratiets sociale substans «, som først gjorde det vard for arbejderklassen at opretholde dette parlamentariske demokrati, så førte forsvaret for de formelle indflydelsesmuligheder stadig mere hen mod en politik, som nedbrød denne »sociale substans« og som medførte legitimationstab for »demokratiet $\ll$.

e) Dermed befordrede socialdemokratiet ufrivilligt den allerede aktuelle radikalisering i befolkningen, som det - for så vidt angik arbejderbevægelsen - bekæmpede på sin egen venstrefløj og først og fremmest i forhold til KPD. ${ }^{46}$ At radikaliseringen også er en følge af deres egen politik, kan organisationerne ikke længere »sanse «, da de på grund af deres interne bureaukratisering forlængst har fjernet sig langt fra de eneste informationskilder, der så at sige er samtidige ${ }^{47} \mathrm{i}$ forhold til kapitalens, nemlig de lønafhængiges kriseerfaringer (og især de arbejdsløses). Omvendt stoler kernevælgerne og medlemmerne på, at organisationerne allerede forfølger den rigtige politik - en paradox kommunikation ${ }^{48}$, hvor begge parter til sidst (fra Papen-kuppet til midten af 1933) håber på den anden, fordi det tidligere var blevet dem indprentet, ikke at handle »selvstændigt«, skønt både ledelse og basis samtidig forventer af hinanden, at der bliver handlet selvstændigt: Parti- og fagforeningsledelser forudsatte jo i deres appeller om ro og tilbageholdenhed, at masserne på det »rigtige tidspunkt « ville være handlingsduelige og modstandsvillige, mens masserne antog, at parti- og fagforeningsledelserne ville være villige og i stand til at bestemme det rigtige tidspunkt. Da endelig karakteren af den nationalsocialistiske magterobring var blevet klar, så var det rigtige tidspunkt for modstand ganske vist tilsyneladende kommet, set ud fra en strikt legalitetsbunden adfærd, men samtidig var virksom modstand imidlertid ikke længere mulig. En tildeling af skyld går i denne sammenhæng netop fejl af en bureaukratiseret organisations strukturelle problem, fra hvis systemiske tvang ingen af siderne uden videre kan gøre sig fri.

Min bestemmelse af krisetendensen argumenterer fra facits standpunkt. Netop denne mulige udgang på udviklingen har den socialdemokratiske arbejderbevægelse ikke anticiperet, fordi den i sidste ende ikke erkendte

46. Smlg. Rainer Torstorffs og Martin Martinys bidrag in: W. Luthardt op.cit.

47. Ernst Bloch: Erbschaft dieser Zeit, Gesamtausgabe, Bd. 4, Frankfurt/M. 1977, p. 122ff.

48. Mht. begrebet om og strukturen i den paradokse kommunikation jvf. Watzlawick/Beavin/ Jackson: Menschliche Kommunikation. Bern/Stuttgart/Wien 1974, især siderne 171ff. - I en analyse af Weimarrepublikken skal problemet nok snarest belyses ved hjælp af en biografisk tilgang. Jvf. Wolfang Abendroth: Ein Leben in der Arbeiterbewegung. Gespråche, redigeret af B. Dietrich og J. Perels, Frankfurt/M 1976; Bernd Rabe: Der sozialdemokratische Charakter, Frankfurt/M 1978. 
krisens dybde og struktur ${ }^{49}$ og fordi dens $\varnothing$ konomiske strategi, hvis formulering var præget af konflikter mellem fagbevægelse og parti, vaklede mellem tiltroen til det $\varnothing$ konomiske systems kræfter til at kurere sig selv og forestillingerne om en aktiv konjunkturpolitik i begrænset målestok. Kort og formelagtigt udtrykt: På den ene side står den forsinkede erkendelse af krisen og den socialdemokratiske arbejderbevægelses manglende evne til at erkende modsigelsesfuldheden i sin egen strategi og i det system, som den selv havde været med til at skabe. På den anden side viser kapitalens synkrone evne til negativ krisepolitik og den programmatisk modsigelsesfulde hhv. diffuse reaktionsevne i det statslige bureaukratis status-quo-politik sig at være politisk overlegen overfor den borgerlige lejr, der bevæger sig mod højre, og overfor en reaktionær massebevægelse.

Sålænge den teoretiske beskæftigelse med denne proces - uanset hvor differentieret den end er - udspiller sig som analyser indenfor rammerne af de strategiske aksiomer og dermed i skikkelse af indbyrdes stridigheder om legitimiteten mellem de forskellige traditionslinier indenfor arbejderbevægelsen, vil man ikke virkelig kunne begribe den på forhånd givne overlegenhed i denne status-quo-politik. Thi strategier tenderer mod at konstruere det store alternativ, mens analysen af samfundsmæssige systemers strukturelle stabilitet og begrænsninger - selv i krisetider - snarere synes egnet til at åbne blikket for de minimale forskelle, som frembyder chancen for politiske handlinger, der skaber eller effektivt blokerer tendenser. $^{50}$

49. Et vigtigt aspekt heri er arbejderbevægelsens teoriers afhængighed af krisefremstillingen og fortolkningen hos det borgerlige samfunds egne meningsbærere. At de dengang fremherskende $\varnothing$ konomiske teorier lige så lidt kunne analysere kriserne er velkendt (jvf. Gerhard Kroll: Von der Weltwirtschaftskrise zur Staatskonjunktur, Berlin 1958 - med de allerede nævnte forbehold over for keynesianske fortolkninger). På venstrefløjen fandtes faktisk kun Eugen Vargas analyser (Uddrag i dennes: Die Krise des Kapitalismus und ihre politischen Folgen, red. E. Altvater, Frankfurt/M 1969); men disse fandt imidlertid ikke megen resonans i arbejderbevægelsen.

50. Thi ud fra modstandernes overlegenhed kan man ikke slutte, at Socialdemokratiets strategi var rigtig, således som H. Skrzypczak gør overfor de Freien Gewerkschaften (Zur Strategie der Freien Gewerkschaften in der Weimarer Republik, in: Heinz-Oskar Vetter (red.) Vom Sozialistengesetz zur Mitbestimmung. Zum 100. Geburtstag von Hans Böckler, Köln 1975, p. $201 \mathrm{ff}$.). 


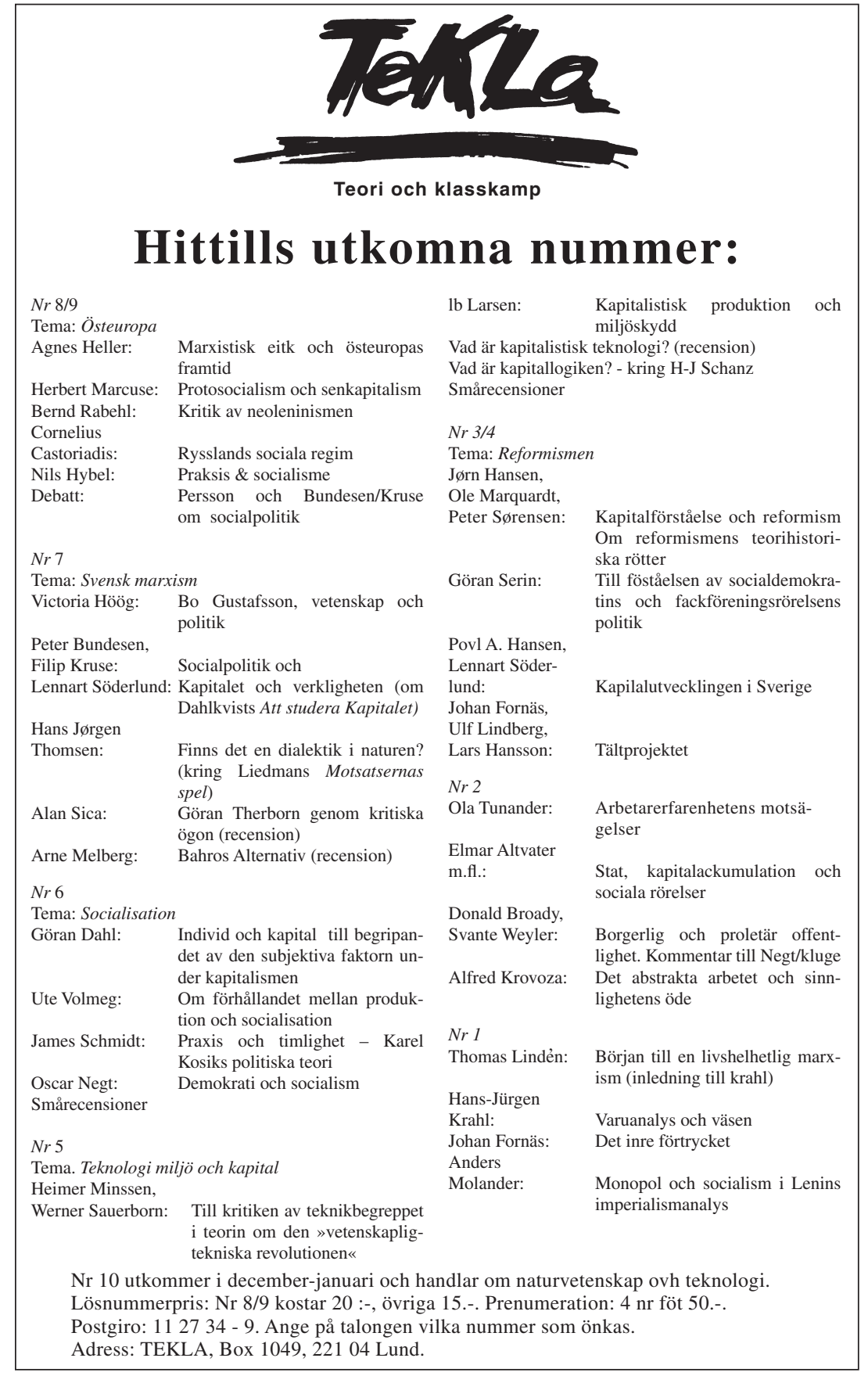




\section{KOMMENTARER OG ANMELDELSER:}

\section{Tiden råber på ............?}

\section{Kommentar til nogle aktuelle tendenser i marxismen}

\section{Finn Dam Rasmussen}

Der er ingen tvivl om at tiden råber på rigtige svar. Derimod er der stor tvivl om, hvilke der er de rigtige spørgsmål og hvordan de skal besvares. Det er i dette perspektiv nogle nyere udgivelser her skal diskuteres: hvilken karakter har marxismens livtag med samtiden?

Da marxismen for mere end 10 år siden startede sit triumftog gennem »venstrefløjen « var den del af en bevagelse, den var i opposition, kritisk overfor og uforenelig med det bestående. $\mathrm{Nu}$ derimod, er marxismen ved at størkne, ved at blive til en position, hvorfra verden dogmatisk kan udlægges, et standpunkt der skal tjene bestemte interesser indenfor det eksisterende samfund, bruges i kampen for individuelle særinteresser. Det samme er ved at ske med »kvindebevægelsen«, den anden store kritiske bevægelse der er gået gennem samfundet og hovederne i de sidste 10 år. Dette er selvfølgelig ikke noget der blot sker og som er uafvendeligt - det er karakteren af vort politiske engagement, vi selv er ved at ændre, selvom det selvfølgelig sker i sammenhæng med nogle samfundsmæssige ændringer, der ligger uden for vor kontrol. I en sådan situation er det vigtigt at skærpe bevidstheden om indholdet i de forandringer vi medvirker til og det er som et beskedent bidrag til denne diskussion, at det følgende skal ses.

»Marxismen« udvikler sig som bekendt $i$ en mangfoldighed af for- 
skellige retninger og opfattelser, og her er ikke tilstræbt noget overblik over disse, men blot diskussion af nogle skrifter, der forekommer mig vigtige og karakteristiske. De to første skrifter, der er af helt forskellig karakter, er sammenstillet, fordi de hermed gensidigt skulle kunne belyse bestemte problemer hos hinanden, nemlig sammenhænge mellem samfundsmæssig væren og bevidsthed. Og det er netop sådanne sammenhænge, der eksplicit tages op i det tredie skrift, der behandles her. Disse skrifter, der skal ses som eksempler på bestemte tendenser i den aktuelle teoriudvikling, har det fælles at de, hver på sin måde, direkte eller indirekte, stiller deres problemer indenfor en »historisk materialisme«, dvs. indenfor rammerne af en teori, der om ikke andet kan kendetegnes ved, at omfatte andet og mere end » $\mathrm{konomi}{ }^{1}$ På en måde er det paradoksalt: I samme omfang som krisen reducerer alle samfundsmæssige, problemer til et spørgsmål om $» \emptyset k o-$ nomi og hermed overtrumfer alle vulgærmaterialistiske forstillinger, i samme omfang bevæger marxismen sig væk fra snævre »økonomiske« problemstillinger og i retning mod teorier om hele den samfundsmæssige kultursammenhæng.

Teori-internt kan dette fænomen vel forstås som reaktion på en vis reduktionisme i den foregående teoriudvikling, men da ingen jo vil tage en sådan forklaring som den fulde, er spørgsmålet for de der mener, at også en teoretisk forholden sig til samfundet har sin berettigelse: Hvad er det der driver vore interesser $\mathrm{i}$ ganske bestemte retninger - for det er jo ikke os selv, der bevidst styrer og udpeger nye »retninger « og »strømninger « $\mathrm{i}$ vore interessefelter, og alligevel opstår disse bevægelser som tydelige og klare samfundsmæssige/ overindividuelle fænomener. Denne problemstilling må en kritisk »historisk materialisme« altså indeholde som selvreflektion.

At betegne sin egen teori som $\mathrm{ma}$ rxisme må være ensbetydende med at teorien ses som formidler af en revolutionær intention. I det følgende forudsættes altså, at marxister idet mindste - har det tilfælles, at de opfatter deres teori som en emancipationsteori. I en stillingtagen til forskellige marxistiske teorier må deres relation til de sociale grupper eller klasser, der skal realisere denne intention unders $\varnothing \mathrm{ges}$, for herigennem at belyse hvorledes den pågældende teori i sin selvforståelse begrunder de erkendelsesmål, den sætter sig.

Der er en snæver sammenhæng mellem, hvad man forstår ved socialisme og »vejen til den« og så hvilke teoretiske opgaver i forhold til den eksisterende kapitalisme, der er relevante og hvilke, der ikke er det. Når dette tilsyneladende banale forhold skal fremhæves, er det, fordi det efter min opfattelse fortrænges i den aktuelle marxisme - der gås ud fra, at marxismen automatisk »tjener revolutionen «. Når forholdet engang imellem gøres explicit, er det som regel med henvisning til en »ydre«, 
funktionel sammenhæng mellem teori og bevægelse (klasse) indenfor rammerne af en generel »strategi «opfattelse, og ikke som et problem, der også er immanent $\mathrm{i}$ teoriens form for begrebslighed. Pointen er, at en bestemt teoris politiske implikationer ikke behøver at fremhæves hvergang et bestemt problem analyseres, men at der udfra form-/indhold i den erkendelse, der søges oparbejdet, lader sig slutte til bestemte socialismeopfattelser, og at en diskussion af teorierne også må omfatte en forholden sig til disse implikationer. Det er således ikke et tilstrækkeligt argument for en given teoris emancipatoriske karakter, at den rent instrumentelt forbindes med de »rigtige « politiske intentioner - problemet bliver altså at undersøge om eller hvordan den ønskede erkendelse begrundes i forhold til en bestemt emancipationsforestilling.

Det drejer sig ikke her om at vurdere andres socialismeopfattelser i forhold til min egen »rigtige « opfattelse, men i første omgang om at rejse spørgsmålet om der »internt « i de forskellige teorier er overensstemmelse mellem deres egne programatisk formulerede politiske intentioner og den erkendelse (form/indhold') de faktisk oparbejder. På baggrund af dette må man da spørge: Hvilken revolutions- eller socialismeopfattelse betinger - eller er betinget af - den pågældende teori, samt hvilket forhold har teorien (explicit og implicit) til den - faktiske eller tænkte - sociale bevægelse, der skal realisere den emancipation teorien foregriber.

\title{
»Realanalysen og den materialistiske historieopfattelse «
}

\author{
(af Andreassen, Bahner, Elling, Kerndrup \& Kjær, i Kurasje nr. 26, \\ 1981)
}

Den første artikel der skal tages op her er en overvejende videnskabsteoretisk programmatisk argumentation for, at en række »realanalyser « udgør en »Materialistisk historieopfattelse«, der er såvel den øvrige danske marxisme som den traditionelle »historiske materialisme« overlegen. Artiklen er således en opsamling af en bestemt nyere »retning $\ll \mathrm{i}$ den danske marxisme, en slags statusopgørelse, men også et fors $\varnothing \mathrm{g}$ på at skitsere en videnskabsteoretisk og politisk ramme for denne retning som sådan forekommer dens intension vigtig og relevant ${ }^{2}$

Artiklen vil begrunde en bestemt teoretisk-politisk praksis, hvilket er yderst legitimt, da det burde kunne bidrage til en præcisering af formålet 
med det teoretiske arbejde der udføres og hermed gøre en diskussion af dette arbejdes politiske relevans mindre kompliceret.

Når jeg skriver »burde kunne bidrage « er det fordi faren for efterrationalisering og legitimering er nærliggende - og en efterrationalisering vil (uanset om den er bevidst tilsigtet eller ej) blot gøre den politiske diskussion yderligere kompliceret. På denne baggrund er den måde artiklen er skrevet på skuffende: stilen er systematisk afproblematiserende. Mange af de stående teoretiske stridsspørgsmål behandles som om de overhovedet ikke udgør noget problem, samtidig med at skinløsninger fremsuggereres gennem gentagelse af kognitivt tomme udsagn indeholdende ord som »virkelig, « »materiel«, osv. Netop anvendelsen af begrebet »materiel« (og materialistisk) kan tjene som eksempel på ovennævnte: Selvom udtrykket anvendes ustandseligt som central karakteristik af helt afgørende pointer hos forfatterne, fors $\emptyset$ ger de ikke et eneste sted at præcisere det, på trods af at en præcisering af hvad »samfundsmassig materialitet « er, både hører til en historisk materialismes mest centrale, men også mest forsømte problemstillinger.

\section{Den danske marxismes degenere- ring}

Andreassen m.fl. trækker indledningsvis paralleller mellem Karl Korsch' kritik af 20'ernes og 30'ernes marxisme og deres egen position. Korsch havde kritiseret datidens gængse marxisme - personificeret ved K. Kautsky - for dens doktrinære og ahistoriske karakter, for adskillelsen mellem teori og praksis. Marxismens daværende krise »skyldes ikke, at teorien er blevet degenereret af epigonerne « (s. 9), men er en krise i selve »Marx-Engels teorien«. Korsch' kritik af marxismen fremsættes sammen med hans berømte tese, om at anvende den historiske materialisme på analysen af den historiske materialisme selv. Når Andreassen m.fl. her trækker Korsch' synspunkter frem, er det fordi de vil tilslutte sig hans program for en praktisk, kritisk, udogmatisk, levende marxisme (- og hvem vil ikke det?) Men som vi skal se, gælder det her, som hele artiklen igennem, at den er opbygget som en række udmærkede programmatiske principper, der imidlertid gøres meningsløse, idet de fuldstændig dementeres gennem forsøgene på at udfylde dem. At forfatterne her således prøver at stille sig på skuldrene af Korsch i hans kritik af Kautsky og Ortodoksien, dementeres af deres egen marxismes slående lighed med Kautskys.

Vi præsenteres her for en automatisk marxisme, en gammel kending i nyt udstyr, en marxisme der ikke kan etablere nogen sammenhæng mellem de »historiske bevægelseslove « og de virkelige, handlende og tænkende, menneskelige subjekter og hvor teoriens relation til samfundsforandrende praksis derfor forsvinder. $^{3}$ Denne automatiske marxisme står aktuelt overfor en anden marxisme, der dyrker hvad man kan kalde 
den abstrakte subjektivitet, dvs. en teori der isolerer bevidsthed og subjektivitet fra de samfundsmæssige processer, hvori de er et integreret moment. ${ }^{4}$

Forfatterne vender sig efter diskussionen af Korsch' synspunkter mod den nyere udvikling i den danske marxisme. Men istedet for at anvende deres "materialistiske historieopfattelse« på denne teoriudvikling, anvender de som forklaringsmodel netop den teori-interne »degenererings-tese «, som Korsch ifølge dem selv havde gjort op med.

Deres kritik er et godt eksempel på »det sociale hukommelsestab $\ll, 5$ som R. Jacoby påviser i psykologiens forhold til sin egen historie, og som totalt fortrænger det vigtige spørgsmål om determinationen af ændringerne i ens egen teoretiske forståelse. Den »materialistiske historieopfattelse« bliver derved på trods af alle principielle besværgelser - netop historieløs i forhold til sin egen historie. Forfatterne går frem på følgende måde: De projicerer deres egne tidligere $»$ fejlopfattelser (eller en karikatur af deres egne tidligere standpunkter) over på andre teoretikere, her Schanz og Altvater (se f.eks. s. 18-19 og 22). Derefter retter de en dødbringende kritik mod disse indlysende tåbeligheder. De kan så udgive de »rigtige« elementer af opfattelserne hos Schanz og Altvater for deres egne og lade som om de altid selv har haft dem. Særlig i forhold til Schanz giver fremgangs- måden absurde resultater - han gøres til fortaler for en formallogisk deduktiv teoriforståelse på trods af, at hans måske væsentligste fortjeneste jo har ligget i opgøret med sådanne opfattelser og i påpegningen af de $\varnothing$ konomikritiske begrebers karakter af fungerende realabstraktioner.

Udover at det her lykkes forfatterne at skabe voldsom uklarhed omkring forholdet mellem teoriernes forskellige abstraktionsniveauer og virkeligheden, er problemet, at en sådan retoucheret historieskrivning aldrig kan formidle erfaringer; den samtidige eksistens af forskellige teoretiske opfattelser af virkeligheden og af teoriens forhold til den bliver aldrig sat i sammenhæng med modsigelser i den eksisterende form for samfundsmæssighed, men blot diskuteret som følger af en forkert teori. Og forfatterne konkluderer: »Rekonstruktionsprogrammet, som på den ene side var udtryk for et nødvendigt og det umiddelbart eneste mulige opgør med den nedarvede 1930'ermarxisme, betød på den anden side en degenerering af marxismen som en materialistisk videnskab ved at blokere for analysen af de virkelige historiske bevægelseslove«. (s. 24)

\section{Tilintetgørelsen af spekulationen}

Herefter vil forfatterne så skitsere deres egen 'materialistiske historieopfattelse'. De vil referere Marx' og Engels' synspunkter omkring »filosofien og det logiske og forholdet mellem logik og historie« (s. 24) 
med det formål, at give en karakteristik af den 'materialistiske historieopfattelse'. De mener at kunne hente deres argumentatoriske skyts i Marx' ungdomsværker »... der kan opfattes som programmatiske formuleringer af den materialistiske historieopfattelse, som gøres gældende i Marx' senere 'økonomiske' værker« (s. 25), hvilket imidlertid ikke indebærer, at forfatterne undersøger om disse »programmatiske formuleringer « har gyldighed, efter at de er udfoldet i de $\varnothing$ konomiske værker. Hvorfor dog henholde sig til programatiske forhåndsantagelser, hvis de rent faktisk er indløst i senere arbejder?

De tager udgangspunkt, der hvor Marx siger, at den virkelige, positive videnskab udgøres af fremstillingen af menneskenes praktiske virksomhed, fordi de vil gøre op med forestillinger om, at det kan være meningsfyldt at kritisere ideologi og filosofi. Andreassen m.fl. fremsætter så følgende påstand: »Fremstillingen af de virkelige, materielle forhold ophæver filosofien og ideologien« (s. 25). ${ }^{6}$ Fremstillingen af de virkelige materielle forhold var jo identisk med videnskaben, så forfatterne fremsætter altså den påstand, at videnskaben ophæver ideologien.

Ideologien ses her ikke som en konstitutiv del af den samfundsmæssige reproduktionsproces og videnskabens opgave ikke som at begrunde ideologiens eksistens og forandring, ikke ud fra den selv, men fra dens relationer til reproduktionsprocessens $\varnothing$ vrige momenter. Denne »materialistiske« teori vil derimod »ophæve« bestemte dele af den samfundsmæssige virkelighed gennem teoretisk fremstilling af andre dele. ${ }^{7}$ Ideologi, osv. forklares og kritiseres ikke udfra »de virkelige materielle forhold «, men reduceres til dem.

Imidlertid er denne opfattelse forudsætningen for at give politisk mening i de efterfølgende overvejelser. Her bringes bl.a. dette Marx-citat: »Men efterhånden som historien skrider frem og proletariatets kamp får tydeligere konturer, behøver de (teoretikerne) ikke længere at lede efter videnskab i deres hoveder; de skal blot aflagge regnskab for det, som foregår for фjnene af dem og gøre sig til talerør for det«. (s. 26)

Man må spørge sig: Hvad er det dog for noget elitært sludder, hvordan skal proletarerne dog kunne lave revolution, hvis de ikke engang selv kan se, hvad der foregår for øjnene af dem, men må have »videnskaben « til at gøre det, og hvordan har Marx her forestillet sig, at det skulle være til hjælp for dem, at nogen aflægger et sådant regnskab - hvordan og hvornår skal det rent praktisk ske? Og til hvem skal talerøret tale? Her mangler næsten bare et af de mange mulige citater fra denne periode, hvor Marx taler om »filosofferne « som den revolutionære bevægelses hoved og proletarerne som dens krop.

Her er tale om et fortolkningskrævende citat, hvis det skal kunne uddybe den politiske mening, Andre- 
assen m.fl. selv lægger i deres teoretiske arbejde og dermed begrunde de specifikke erkendelsesmål, som de forfølger. Men den fortolkning af citatet, de forsøger sig med, undviger imidlertid helt denne problematik.

Vi har her at gøre med det gammelkendte problem om forholdet mellem intellektuelle og proletariat og det kunne jo være spændende at høre lidt om, hvordan videnskabens vidunderlige ideologiske vaskekraft skulle forvaltes af videnskabsmændene. Forfatterne stiller da også problemet: »Men hvordan skal dette regnskab aflægges?« og foregriber straks selv svaret: »det kan ikke blot være et spørgsmål om at udarbejde en protokol over dagens begivenheder« (s. 27). Tilsyneladende mener de, at problemet kun er et teori-internt spørgsmål og afviser protokollen fordi en sådan fremgangsmåde vil være dårlig videnskab (»abstrakt empiri«). De søger derfor at besvare spørgsmålet gennem en diskussion af, hvorledes det korrekte forhold mellem »logik og historie « skal se ud. Hermed gøres problemet om hvordan dette »regnskab « skal aflægges til et rent metodisk og ikke et samfundsmæssigt spørgsmål om deres eget og deres teoretiske arbejdes forhold til andre dele af lønarbejderklassen, om opgør med arbejdsdeling, om herred $\varnothing$ mmefri organisationsformer, om radikalt demokrati, osv.

Det var jo omkring problemerne om »logik og historie «, at nogle afgørende skillelinjer mellem for- skellige Marx-forståelser (og i forlængelse heraf forskellige socialismeopfattelser) markeredes under det store marxisme-boom fra slutningen af 60erne og fremefter. STAMOKAP teorierne repræsenterede dengang den opfattelse, at »Kapitalen« var en fremstilling dels af den »simple vareproduktion «, dels af »konkurrencekapitalismen «. Marx' arbejde måtte derfor videreudvikles af Lenin (monopolkapitalisme), og da kapitalismen på trods af hans diagnose overlevede sit »sidste stadium «, måtte Lenin suppleres med teorierne om »statsmonopolkapitalismen«. I kritik af denne opfattelse udvikledes den senere s.k. »kapitallogik«, der mente, at »Kapitalen« var en teoretisk rekonstruktion af de i virkeligheden fungerende systematiske sammenhænge, der netop gjorde kapitalisme til kapitalisme og som følgelig havde gyldighed i alle kapitalistiske samfund. En sådan teoriforståelse har sit eget særlige »empiri-problem «, men på trods af mange forskelligartede løsningsfors $\varnothing \mathrm{g}$ er det ikke lykkedes at udvikle noget overbevisende svar på dette videnskabsteoretiske grundproblem. Når Andreassen m.fl. diskuterer »logik og historie « forholder de sig således implicit til en omfattende debat indenfor deres egen tradition, og deres totalt afproblematiserende tilgang virker på denne baggrund som et stort tilbageskridt. Det er næsten for meget, når de må gribe til en spidsfindig udlægning af netop de selvsamme Engels-citater, der i sin tid legitimerede STAMO- 
KAP teoriernes »historiske« læsning, for at få argumantationen til at hænge sammen.

I deres behandling af »logik og historie « lykkes det dem at skabe utrolig forvirring omkring disse i forvejen indviklede problemer. De lægger ud med et referat af og en tilslutning til Engels' overvejelser ${ }^{9}$ af forholdet mellem en historisk og en logisk betragtningsmåde, ${ }^{10}$ men ender med en modstilling af »historiske « og »logiske « n $\phi d v e n d i g h e d e r$. Engels synspunkt er, at den logiske betragtningsmåde faktisk er principielt den samme som den historiske, blot renset for »forstyrrende tilfældigheder «, hvilket imidlertid gør det vanskeligt at få mening i forfatternes sondringer mellem »logisk « og »historisk «. Hvis »logikken « er den rensede »historie«, så må det jo f.eks. betyde, at når forfatterne taler om »logiske følger«, »logiske nødvendigheder«, etc. så er disse samtidigt »historiske«. Dette resulterer f.eks. i - med et pænt ord - kryptiske formuleringer som: »Dette begreb eller teori vil ikke kunne udledes af de almene begreber, omend det vil være en både logisk og historisk følge af dem«. (s. 30)

Det bliver aldrig klart, hvorledes forfatterne opfatter forholdet mellem teori og virkelighed, mellem realabstraktion og tankeabstraktion, mellem reallogik og tænkelogik, mellem virkelig historie og teoretisk fremstilling af denne - deres tidligere kritik af Schanz's påståede deduktive logik positiveres ikke her gennem overvejelser over dialektisk logik. Man blir spist af med tomme fraser som: »... produktionsforholdenes historiske udvikling må levere de kategorier, som de virkelige materielle forhold må fremstilles igennem«. (s. 27)

Efter nu at have kritiseret marxismens elendighed og derefter »givet en karakteristik af den materialistiske historieopfattelse«, vil Andreassen m.fl. så til slut demonstrere $» . .$. hvordan en materialistisk historisk rekonstruktion af marxismen må tage sig ud«. (s. 8) Det gør de ved en gennemgang af nogle af deres egne s.k. realanalyser »som vi mener tendentielt overskrider disse blokeringer« (s. 24) som marxismen iøvrigt sidder fast $\mathrm{i}$.

En historisk aktuel marxisme: to abstraktioner og en generalisering På trods af deres kritik af andres indsnævrede historieopfattelse ser Andreassen m.fl. det centrale problem i deres egen »historisk aktuelle marxisme « som forholdet mellem $»$ værdi og pris «. Imidlertid mener de i relation til dette problem, at formforvandlingen - konkret arbejde må udtrykkes som pris - »er selvindlysende «. Problemet angår alene det størrelsesmæssige forhold mellem værdi og pris. Problemstillingen er derfor: hvorfor falder værdi og pris størrelsesmæssigt fra hinanden«. (s. 33) For mig er »formforvandlingen « langtfra selvindlysende og slet ikke til at adskille fra »det størrelsesmæssige forhold mellem værdi og 
pris « - når værdi og pris iflg. forfatterne »størrelsesmæssigt falder fra hinanden « hvilken 'fællesnævner' vil de da bringe værdi og pris på, for at konstatere denne falden fra hinanden? Ifølge deres egen opfattelse kan man nemlig ikke gå ud fra »et generaliseret forhold mellem værdi og pris«, (s. 37) (således altså heller ikke fra en generel antagelse om deres »falden fra hinanden $\ll$ ), forholdet er historisk specifikt. Men hvordan undersøger man så det historisk specifikke forhold mellem værdi og pris? ${ }^{11}$

$\mathrm{Ja}$, det gør man iflg. forfatterne ved at erstatte de generelle antagelser af forholdet værdi-pris, »som fører til vilkårlige og ukontrollerede abstraktioner « (s. 37) med gyldige abstraktioner i forhold til den undersøgte konkrete historie - problemerne om disse abstraktioners gyldighed kan bedst belyses ved eksempler og det sker under overskriften: »realanalyse som begrebsliggørelse af den konkrete historie«, hvor forfatterne gennemgår to af deres egne tidligere artikler.

Det ene eksempel drejer sig om »et fors $\varnothing \mathrm{g}$ på at fastlægge den statslige krisepolitiks historisk specifikke begreb «, (s. 39). Imidlertid betragtes politikken ikke som en samfundsmæssig proces, som specifik menneskelig praksisform, men som en række ( $\varnothing$ konomiske) resultater, og det understreges at statspolitikken ikke er resultat af »ideer «, men »af den materielle virkelighed « (s. 40). Igen et argument, der gør det overflødigt at analysere et fænomen som politik, der er »forklaret« i og med fremstillingen af den »materielle virkelighed « - hvortil den åbenbart ikke selv hører. Andreassen m.fl. gør nu, hvor deres program skal realiseres, selv alt det, de i det foregående har kritiseret andre for: de lægger ud med »... en teoretisk afledning af alle det borgerlige samfunds $\varnothing$ konomiske fremtrædelser udfra det ukritisk antagede, aksiomatiserede grundbegreb: 'værdi' «. (s. 10) De tvinges til »,... at bortabstrahere alle de historiske forhold eller sider af historiske forhold, der ikke fremstår i prisform...«. (s. 23) De foretager »... en vidtgående indskrænkning af, hvad der overhovedet skal forstås ved historien eller ved det empiriske«. (s. 32)

Den omtalte artikel, der her bruges som eksempel på den historisk aktuelle marxisme, løser sit »... empiriske problem gennem to abstraktioner og en generalisering «. (s. 41) Der abstraheres fra verdensmarked og fra handelskapitalen og »den industrielle arbejders « udbytningsforhold generaliseres $» .$. som et gyldigt udtryk for den produktive totalarbejders udbytningsforhold og profitproduktion «, (s. 42), og resultatet er at »Transformationslogikkens fiktive problemer og parallellitetsbetragtningens blokeringer forsvinder således med en bevidst anvendelse af abstraktioner, som er gyldige i forhold til undersøgelsesfeltet«. (s. 43)

Alle de dyre ord om at sætte historien på begreb med begreber som virkelighedens egen udvikling leverer, fiser ud i nogle snusfornuftige 
overvejelser om, at verdensmarkedet »næppe « spiller nogen rolle, at »forholdene skal være meget afvigende « hvis den ene generalisering ikke skal gælde, osv.

\section{En hel og praktisk marxisme}

I deres afslutning understreger forfatterne to ting: en historisk aktuel marxisme må være praktisk og den må være hel, dvs. kunne forstå »hvordan de materielle forhold overhovedet betinger 'den sociale, politiske, og åndelige livsproces' «. (s. 46) Den marxisme de har præsenteret er imidlertid ingen af delene.

Hvori skulle denne teoris praktiske karakter bestå? Ja, for såvidt Andreassen m.fl. overhovedet er inde på praktisk-politiske implikationer af deres teori er det i den ovennævnte sammenhæng, hvor de vil gøre sig til $»$ talerør«. De mener tilsyneladende, at deres forsøg på at fremstille »de virkelige materielle forhold « $g \varnothing r$, at deres teori blir materialistisk og praktisk. Det gør den ikke; en anskuende materialisme som den vi her er blevet præsenteret for, bliver ikke mindre anskuende (og altså praktisk-forandrende) ved, at det er det praktiske liv den anskuer. En praktisk teori må være en der griber forandrende ind og det eneste en teori kan forandre er jo menneskenes bevidsthed. Men den her præsenterede teori når aldrig frem til de virkeligt fungerende, praktiske, samfundsmæssigt gyldige tankeformer, men forblir på et underligt generaliseret ingenmandsland, et niveau for »beregninger« og »resultater - der højest kan interessere statslige planlæggere, virksomheds- og fagforeningsledelser samt andre af de borgerlige politikformers traditionelle subjekter. Men pointen er måske, at det netop er blandt disse, at forfatterne vil lokalisere politisk praksis, at det er her, de vil gøre sig til talerør?

I deres begejstring for »videnskab« og »materialisme « glemmer de helt den marxske teoris specifikum - som også må gælde en historisk aktuel marxisme - nemlig kritikken. Marx har ganske vist et program der hedder »kritik durch Darstellung «, men det implicerer jo ikke, at enhver fremstilling dermed er kritik. »Materialismen« er heller ikke et programmatisk standpunkt, der er identisk med kritik, og forfatterne glemmer helt at »Den unge Marx var kommet frem til marxismen gennem en radikal kritik af den hegelske filosofi, men samtidigt, gennem en ligeså radikal kritik af materialismen. ....For den unge Marx er filosofisk materialisme således en nødvendig, men utilstrækkelig betingelse for revolutionær teori ...«. ${ }^{12}$ Netop i dette perspektiv forekommer forfatternes brug af $\mathrm{K}$. Korsch at være et misbrug, idet han fremfor nogen understregede betydningen af kritikken af materialismen. Denne form for omgang med marxismens historie har katastrofale konsekvenser i form af »hukommelsestab «: det reelle indhold i tidligere kontroverser går tabt, og det der kunne blive til erfaring reduceres til ideologisk udsmykning på et helt anderledes indhold. 
Hvordan skal denne »materialistiske historieopfattelse' blive til en »hel marxisme« som forfatterne kræver? Deres »materialisme« er jo en udraderings-metode - det er nemlig ikke sådan i denne teori, at fænomener som ideologi og politiks tilsyneladende selvstandighed skal ophæves, ved at disse fænomener forklares ud fra deres sammenhæng med $\gg$ den materielle, praktiske livsproces«, men fanomenerne selv »ophæves«, »tilintetgøres«. I denne »praktiske materialisme« behøver man ikke kritisere virkelige fænomener som ideologi og politik - man tilintetgør dem derimod gennem en videnskabelig fremstilling af deres »materielle grundlag $«$ !

Hvordan opfatter forfatterne eksempelvis »politik i den artikel de fremhæver som eksempel på en hel og praktisk marxisme? Politik, siger de ».... må forstås som et sammenfattende resultat af de materielle betingelser for kapital, stat og arbejderklassens ageren under de givne historiske omstændigheder«. (s. 40)

Men hvorledes forholder denne politikforståelse sig til kravet om at teorien skal være praktisk? En praktisk revolutionær teori må se politikken som en proces, hvori mennesker handler, erfarer, lærer, og må bearbejde disse aspekter til erfaring. Men i ovenstående politikdefinition er ethvert spor af (lære)- proces forsvundet, det der er tilbage er $\gg$ resultater « - hvis eneste fordel er, at de kan udlæses af den tilgængelige statistik.
I denne opfattelse reduceres politik til og identificeres med sine »materielle betingelser «. Det der skulle begribes, nemlig en specifik del af samfundet, hvor mennesker (individer, grupper, klasser) handler og hvor de har mulighed for at erfare bestemte samfundsmæssige modsigelser, forsvinder ud af teorien. Når der kan abstraheres fra subjekternes handlinger og bevidsthed på denne måde, må det være, fordi disse handlinger ses som entydige, »logiske« følger af de »materielle betingelser «.

Problemet er imidlertid, at der ikke findes nogen entydig logik eller kausal-sammenhæng mellem »materielle betingelser « og »handlinger«, men at det præcis er sådanne sammenhænge, der er problemstillingen i teorier om eksempelvis politik og ideologi. Reduktionen af disse fænomener til deres »materielle betingelser « overser at betingelserne selv må reproduceres, og at denne reproduktion er formidlet, bl.a. gennem ideologi og politik. »Materielle betingelser « og »resultaterne« lader sig simpelthen ikke forbinde uden oparbejdelse af de formidlende samfundsmæssige processer, som i denne forstand er medkonstituerende.

Hertil kommer - som allerede påpeget - den utrolige uklarhed der er i udtrykket »materielle betingelser «. Betyder »materiel « ikke materie i fysisk forstand (og det vil jo i sammenhængen være meningsløst - desuden er der vist slet ikke noget, der hedder sådan nu om dage), må det betyde 
noget i retning af forhåndsstruktureret, »institutionaliseret« reproduktionspraksis - og så er den entydige opdeling i materielle betingelser og handlinger/bevidsthed ikke mulig. En nærliggende fare i en ukritisk materialisme er, at »materialistisk « får den betydning, det havde i 3 . Internationales marxisme: »den materialistiske betragtning af verden, det vil sige betragtningen af masserne som materiale... «13

Den her kritiserede politikforståelse lader sig ikke forbinde med de handlende subjekters bevidsthed. Denne abstrakte »resultattænkning « er parallel med reformismens klassiske tankemønster, som det kritiseres af Rosa Luxemburg. Hun fremhæver netop, at set i revolutionært perspektiv er klassekampenes resultater underordnede, det der er vigtigt, er de erfaringer arbejderklassen vinder $\mathrm{i}$ disse kampe, den bevidsthed, organisation, etc. der fremgår af kampene, og disse kan ikke opfanges teoretisk gennem en analyse af »resultaterne «. Men hvorledes skal Andreassens m.fl. form for marxisme kunne give et praktisk bidrag til en sådan erfaringsbearbejdning - og hvis den vil noget helt andet, hvad er så det?

Denne subjektløse marxisme formår tilsyneladende ikke at bringe sig selv i dialog med aktuelle samfundsmæssige tendenser. Disse processer reduceres til deres »resultater « og disse lader sig igen let indordne i på forhånd fastlagte almene lovmæssigheder, s.k. »logiske muligheder «. Den unge Marx, som forfatterne ci- terer med så stor forkærlighed, retter en kritik mod gammelheglianernes brug af Hegels teori, som er en præcis karakteristik af denne 'materialistiske historieopfattelses' brug af Marx: „Gammelheglianerne havde begrebet alt, såsnart det var ført tilbage til en logisk kategori hos Hegel«. (MEW 3, s. 19)

Slutteligt vil jeg tilslutte mig følgende forslag: »En konstruktiv kritik af den aktuelle konception af den historiske materialisme kunne munde ud $i$ et forslag om at vende hele fremgangsmåden om, og istedet for at ville indordne de menneskelige subjekters virksomhed i et forfixeret skema af 'objektive processer' og deres lovmæssige korrelationer, snarere at udgå fra denne subjekt-virksomhed og dens bevæggrunde og ud fra dens konstellationer og betingelser at begrebsliggøre resultaterne (af hvilke subjekterne så igen træffes og bliver stimuleret til yderligere aktiviteter) og processens totale 'gang' ${ }^{*}{ }^{14}$ En sådan tilgang har naturligvis også sine problemer, men vil - hvis forfatterne følger forslaget - i det mindste kunne bruges til effektivt og detaljeret at problematisere deres opfattelse af, hvad det vil sige at »sætte historien på begreb«. Spørgsmålet rejser sig nemlig, om der er noget $\mathrm{i}$ Andreassens m.fl. tilgang, der peget på, at det skulle være muligt gennem deres »historiske analyse « at finde de almene lovmæssigheder i den virkelige historie - hvis de altså ikke havde været givet som forudsætninger for analysen? 


\section{»Moral og forandring«}

\section{(Temanummer af tidsskriftet HUG!, nr. 29, 1981)}

HUG! er et tidsskrift af en lidt anden karakter end Kurasje, og umiddelbart virker det måske derfor urimeligt at diskutere det her i sammenhæng med teoretiske grundproblemstillinger fra den historiske materialisme. Når jeg gør det, er det fordi jeg mener, det har alvorlige konsekvenser at adskille den »teoretiske« fra den mere aktuelt-politisk-personlige debat og afklaring. Det indebærer ikke, at enhver politisk kommentar behøver diskutere teoretiske problemstillinger. Derimod er det sådan, at en forholden sig til aktuelle problemer også er formet af den teoretiske forståelse man har, hvorfor det er af politisk betydning at fremdrage den. I et socialistisk tidsskrift som HUG der både vil og kan medregnes til en historisk materialisme - bør marxistiske teoremer altså være integreret, også i mindre »teoretiske « artikler, hvis ikke marxismen blot skal være til søndagsbrug. Det må derfor være relevant at se på, hvad det er for en marxisme, der er på spil her.

HUG! kan ikke siges at repræsentere en »subjektløs« udgave af marxismen, idet tidsskriftets hovedtema generelt har været forskellige aspekter af »subjektiviteten « (bevidsthed, sexualitet, osv.). Også dette temanummer om moral hører til denne problemkreds. I diskussionen af Kurasje-artiklen gik hovedkritikken på, at menneskelig handlen og bevidsthed ikke lod sig begribe som momenter af den samfundsmæssige reproduktionsproces. Det samme problem - en af den historiske materialismes kerneproblemer, forholdet mellem samfundsmæssig væren og bevidsthed, »basis og overbygning « tematiseres her fra den anden side: hvordan tænkes sammenhængen mellem objektive samfundsmæssige struktursammenhænge og reproduktionsformer og så individernes normativt bestemte handlinger, når indfaldsvinklen er »moral $\ll$ ?

\section{Lidt om formen}

HUG! redaktionen mener, at problematikken om »moral « er ny, at »... måske er kodeordet til det nye, der sker, 'moral' «. (s. 6) $)^{15}$ Måske ja, men problemet $\mathrm{i}$ en sådan stillingtagen ligger i, hvad der egentlig skal forstås ved 'moral' - og her synes jeg ikke man kan hente nogen hjælp til præcisering i HUG! $!^{16}$ Redaktionen vil formodentlig så svare, at det netop ikke kan dreje sig om definitioner her, men om afs $\varnothing$ gningen og indkredsningen af nye felter og problemer. Istedet vil jeg altså spørge: åbnes virkelig disse felter, perspektiveres de, stilles de vigtige problemer, osv.?

Idet jeg foregriber den følgende argumentation, vil jeg påstå, at det ikke lykkes - helhedsindtrykket er, at man føler sig lidt snydt og skuffet, på trods af flere gode enkeltbidrag. Jeg 
tror grundlæggende dette udspringer af en modsætning mellem dette HUG!-nr' form og indhold: Indholdet er forsøg på nye tanker og veje, og er derfor i sagens natur ikke blot uafklaret, men også uklart. Formen er fors $\emptyset$ gt gjort »let«, tiltrækkende og salgskraftig, udformet som en mosaik af korte essays, digte, illustrationer osv. Resultatet bliver ikke den tilstræbte »lethed «, men overfladiskhed. Nummeret bliver revet $\mathrm{i}$ stykker mellem temaets egne krav og markedets.

Det er klart, at man ikke kan andet end sympatisere med intensionen om at gøre emnet »spændende « - men er der ikke indholdsmæssig dækning herfor, ender det blot som en (umoralsk?) markedsføringsstrategi. For mig er der f.ex. ingen tvivl om, at billeder ofte kan supplere og uddybe en tekst, og at det kan ske på mange forskellige måder, ikke bare som traditionelle »illustrationer«.

Men jeg har svært ved at se relationer mellem tekst og billeder ret mange steder i dette HUG! - bortset selvfølgelig fra de helt oplagte tilfælde, som når f.eks. en artikel af Hans-Jørgen Nielsen om Hans-Jørgen Nielsen ledsages af et stort portræt af Hans-Jørgen Nielsen. Eller tager man et andet element i HUGs udformning som sproget: Alle er vi dødtrætte af det tørre, endimensionale »videnskabelige « sprog, der normalt anvendes i artikler, etc. - rimeligt nok, ligesom det er udmærket at prøve at gøre noget ved det. Men uden reelt indhold bliver et poetisk billedsprog som det, der anvendes f.eks. i den redaktionelle indledning kun jargon. Hvad skal man stille op med formuleringer som: mennesker der $» . .$. i dagliglivet er hjælpeløse og frustrerede som strandede albatrosser « eller, venstrefløjen der består af »fremtidsdyr «? Den slags formuleringer vækker mistanken, at de slet ikke skal bruges til at tydeliggøre et budskab, men skal tjene helt andre formål.

Selve tanken om at opbygge et tema ved at belyse det fra mange forskellige indfaldsvinkler er ganske vist god nok, men forudsætter en »ramme «, der kan perspektivere de forskellige indslag. En sådan ramme - formuleret eller ej - kan jeg ikke finde i nummeret. hvilket også gør, at visse centrale problemstillinger helt forbigås og de fleste af indslagene falder for fristelsen til at møde moralske problemstillinger på disses eget terræn og derfor let ender i det moraliserende. For at undgå dette er det netop vigtigt, at behandle »moralen « indenfor rammerne af en historisk materialisme.

Tænkning i moralske kategorier tenderer til polært at fordele ondt og godt på forskellige handlingskategorier og er således ikke på højde med den marxske emancipationsteoris modsigelsestænkning: Kapitalismen som i udbyttende og undertrykkende former producerer muligheden for et andet samfund ikke bare i objektiv betydning (produktivkræfter), men også - måske først og fremmest - 
i subjektiv forstand. Det praktiske krav om socialisme er jo ikke imanent i menneskeheden, men specifikt historisk produkt, dvs. kræver den samfundsmassige produktion af en specifik »psykisk udrustning « hos individerne. Hvilken rolle spiller $»$ moralen $\ll \mathrm{i}$ denne proces?

\section{Verdens og moralens fragmentering}

»Moral « er vel normative udsagn om menneskelige handlinger, men kan ikke blot være en hensigtslegitimering. De moralske udsagns karakter eller »natur « er noget absolut eller kategorisk, principielt og almengyldigt. Relativering af moralske udsagn er derfor underminering af dem. Hermed opstår problemet om moralens eksistensbetingelser i de moderne kapitalistiske samfund: ikke blot i den »klassiske« betydning, at de moralske imperativer må syntetisere klassernes kvalitativt forskellige livsbetingelser, men også i den dimension der er karakteriseret ved at menneskenes tilværelse fragmenteres i en række tilsyneladende selvstændige »livsverdener«, med hver deres eget, indbyrdes uforenelige normsæt. Hvilke handlinger der er rigtige eller forkerte, gode eller onde afhænger af den givne sociale sammenhæng. Der er i den aktuelle kapitalisme næppe plads til et eneste moralsk princip, der kan trancendere de mange livsverdener. Moral bliver tendentielt noget relativt og snarere end at være en rettesnor for handling bliver den til adhoc legitimering af indbyrdes uforenelige prin- cipper. Det jeg her prøver at antyde er, at »moral« er et yderst specifikt historisk fænomen, ikke bare i den forstand at »moralens « indhold hele tiden ændres, men også i den betydning, at selve eksistensen af fænomenet moral, er knyttet til bestemte historiske betingelser.

Disse betingelser, moralens samfundsmæssige konstitutionsbetingelser, synes jeg imidlertid ikke tages op i HUG! og af den manglende konfrontation med denne problematik - der som nævnt betyder, at moralproblematikken hovedsageligt må angribes moralsk - følger en modsigelse i temanummeret: Der tales hele tiden om moralen, som om der fandtes en eneste, selvom virkeligheden faktisk er taget til efterretning og temaet netop er opbygget omkring behandlingen af en række »sfære-specifikke « moraler: Borgerlig moral og venstreorienteret moral, magt-, og arbejds- sexualmoral, osv. Hvis moralens eksistensmedium er en sammenhængende verden, hvad betyder da verdens fragmentering for »moralens « fremtidige skæbne?

Med kapitalismens udvikling sker der en $»$ gennemkommercialisering « af alle samfundsmæssige sfærer, hvorved ækvivalent-relationer gøres til paradigma for alle sociale forhold. Hermed reduceres samtidigt de mulige moralske dilemmaer for individerne; moral og kynisme, det nyttige og det rigtige dækker hinanden. Måske var det sådanne sammenhænge Marx havde i tankerne da han sagde: »Den generelle prostitu- 
tion fremtræder som en nødvendig fase i udviklingen af de personlige anlægs, evners, færdigheder og aktiviteters samfundsmæssige karakter«. (Grundrisse s. 74)

Man kan fortolke dette udsagn således: gennem den absolutte fremmedgørelse, objektivering og fetischering af de adfærdsformer der reguleres normativt (bl.a. gennem moral) sker en - ganske vist i fordrejet skikkelse - befrielse af den »indre naturs « naturgroethed. Den kyniskrationelle, kalkulerende forholden sig til og sjakren med sig selv, sine følelser og sine relationer til andre mennesker skaber historisk set et grundlag for, at den praktiske bevidsthed bevidst kan forholde sig til og forme disse relationer. I dette perspektiv udgør traditionelt moralsk forkastelige fænomener som f.ex. »pornografi« en langt mere modsætningsfyldt bestemmelse, end blot at være spekulation i undertrykte behov: Idet »sexualiteten « instrumentaliseres, fremmedgøres, bringes på vareform som masseprodukt, og bliver et forbrugsgode, etableres der også den distance og relativering, der giver mulighed for praktisk at stille spørgsmålet, om hvad denne sexualitet egentlig er, for herigennem at overskride det herredømme som en uidentificerbar og naturgroet form for sexual- og følelsesliv udøver over individerne.

Man kan sige, at ovennævnte tese hos Marx indeholder et velkendt »genfødsels-tema«, ofte formuleret som en »rejse-metafor «: Menneskene må vandre gennem den absolutte fremmedgørelse, instrumentalisering, relativering og kynisme for at »komme ud på den anden side «, befriet og bevidst, nu istand til at ændre de betingelser der skabte fremmedgørelsen. Uanset om denne figur er holdbar eller ej, så peger den på et problem der er centralt når venstrefløjen diskuterer (sin) moral. Grundtanken i tesen er nemlig at fremmedgørelsen, kynismen, »den generelle prostitution«, osv. må gennemleves, erfares praktisk, altså ikke kun gennemtænkes, anskues. Det betyder, at hvis venstrefløjen gør sig til en enklave med sin egen »socialistiske« moral (en enklavemoral ligesom spejder-moral) afskærer denne moral venstrefløjen fra de erfaringer andre gennemlever. Det kan føre til en fortænkt moraliseren om »falske og ægte behov« (hos de andre!), hvor falske behov fordømmes i et fortvivlet forsøg på at undsige sig fascinationen fra dem. Tanken om at komme »genfødt« ud på den anden side implicerer altså, at man sætter sig selv på spil i de samfundsmæssige modsigelser, involverer sig i livet, for denne »rejse « følger netop ingen ensrettet kongevej - resultatet er usikkert. Man kan altså - iflg. en sådan tankegang - ikke blot ved en teoretisk skelnen mellem sande og falske behov og gennem forsagelse af de falske - gennem en »socialistisk moral « her og nu lave et socialistisk menneske ud af sig selv. Livet må gennemleves før det virkelig kan blive materiale, hvoraf der kan dannes erfaringer. 
Hermed har jeg villet prøve at antyde, at moralske problemer ikke bør abstraheres ud af den kapitalistiske udviklings samlede modsigelser, men bør sammentænkes med en forståelse af, hvordan historiske erfaringer overhovedet produceres. Skilles moral, i et marxistisk fors $\emptyset \mathrm{g}$ på at begribe den, ud fra livet i den form det faktisk leves og erfares her og nu, vil venstrefløjen finde sig selv i en situation, der ligner præstens, når han i skriftestolens beskyttede rum skal moralisere over den ukendte verden udenfor.

\section{Borgerlig og socialistisk moral}

HUG-nummeret består af mange mindre artikler og det er ikke her muligt at kommentere dem alle. Udover de artikler jeg i det følgende vil gå ind på, bør en artikel af Steffen Kiselberg om forskellige tidsdimensioner i socialismeopfattelser og en præsentation af Agnes Hellers »moralske antropologi « skrevet af Preben Kaarsholm nævnes som særlig læseværdige.

Torben Hviid Nielsen behandler i en artikel - der er det nærmeste numret kommer en »oversigt « eller »ramme « - ikke bare den borgerlige, men også »en socialistisk morals dilemmaer«. Han argumenterer for, at med kapitalismens udvikling skete 3 ideologiske brud, der har ført til den gradvise opgivelse af en borgerlig moral og til at denne er blevet erstattet af dannelsesidealer og attituder. De 3 brud udgøres af følgende: 1) politikken bliver skilt ud fra moralen, 2) egennytten fører ikke til fælles bedste, 3) sammenhængen mellem intention og konsekvens af handlinger forsvinder. Følgen heraf er: »Den daglige moral er hverken kategoriske imperativer eller dannelse, men er mere og mere blevet tommelfingerreglernes minimumsmoral. Relativismen er blevet det herskende udtryk for erkendelsen af, at der ikke kan træffes entydige valg mellem konkurrerende normative sætninger«. (2. 21)

Problemet er imidlertid, at THN entydigt relaterer »borgerlig moral « til »borgerskabet « men samtidig tildeler denne moral almen samfundsmæssig gyldighed. Det for mig at se centrale problem om de specifikke modsigelser i arbejderklassens borgerlige moral, samt det forhold at »borgerlig moral « langt mere sigter på og er forenelig med arbejderklassens adfærd, tages imidlertid ikke op. Istedet for at binde diskussionen af moralen op på udvikling i klassestruktur og praksisformer i den aktuelle kapitalisme - hvad der jo evt. ville kunne understøtte HUGradaktionens tese om at »kodeordet til det nye er moral«, - argumenterer THN immanent moralfilosofisk med helt store kategorier, hentet fra Adam Smith, Machiavelli, J.S. Mill, Max Weber, osv. og forsåvidt arbejderklassen overhovedet kommer på tale, er det som bærer af en »socialistisk moral «. Hans politiske konklusion på diskussionen af den borgerlige moral retter sig derfor også mod borgerskabet: »I det nuværende ideologiske 
klima er der god grund til at fastholde borgerskabet på, at den borgerlige moral selv har en udvikling og et sæt af dilemmaer«. (s. 21) Det forbliver uklart hvorfor og hvordan en sådan fastholden skal finde sted - men formodentlig er det en del af en af de »strategier «, der tales så meget om i artiklen. Men såvidt jeg kan se, kan det ikke dreje sig om andet, end at prøve at mobilisere en moralsk ansvarlighed hos borgerskabet?

Med »socialistisk moral« mener THN den moral socialister har - eller måske snarere bør påtage sig - i det borgerlige samfund. ».... socialister står med i al fald håbet og gerne også det andet ben i et andet samfund. $\mathrm{Og}$ i den forstand gælder for socialismen moralske normer, der ligger hinsides det samfund, som socialister i dag ikke desto mindre er borgere $\mathrm{i} \ll$. (s. 22) Det spørgsmål man umiddelbart må stille her er, hvorfra en sådan socialsitisk moral henter sit indhold, sine gyldighedskriterier, samt hvilke former for praksis den skal angive normer for.

Iflg. THN kan den socialistiske moral ikke hente sin substans i arbejderklassens interesser, idet interesserne implicerer en reduktion af behovene, men bør være en »behovs-moral «. »Med velfærdssamfundet, med arbejderbevægelsens delvise integration i det borgerlige samfund og med psykoanalysen som videnskab blev denne interesseopfattelse imidlertid - også som en beskrivelse - både samfundsmæssigt og videnskabeligt set mere og mere out of date. Og med 'det nye venstre' er den politiske og teoretiske orientering med rette blevet forrykket fra interesserne imod behovene, og dermed også til personlighedstypen «. (s. 24) THN opregner 3 dilemmaer for en behovsmoral idag: 1) forholdet mellem »sande « og »falske « behov, 2) interessekampen, og dens retfærdigheds- og lighedskrav, 3) behovene og magten.

Problemet i denne diskussion er at udgangspunktet er så uklart. Havde man fået en klar forståelse af forholdet mellem borgerligt samfund og borgerlig moral, kunne man herudfra nærme sig det langt mere komplicerede problem om en ikkeborgerlig (socialistisk) morals eksistensbetingelser, indhold og funktion i et borgerligt samfund. Men socialistisk moral (dvs. moralen i en socialistisk bevagelse) er derudover jo ikke uafhængig af, hvorledes det forholder sig med moralen $i$ et socialistisk samfund. Alt efter hvorledes moralbegrebet præciseres, kan man sige, at et socialistisk samfund er et samfund domineret af moralsk regulering af den samfundsmæssige reproduktion, eller er et samfund, hvor moralen slet ikke eksisterer. I »Det kommunistiske Manifest « retter borgerskabet netop denne anklage mod kommunisterne: »Men kommunismen afskaffer de evige sandheder, den afskaffer religionen, moralen, istedet for at omforme dem....«. (MEW 4, s. 480)

Men skal der være en socialistisk moral, må den have en anden karakter end den borgerlige. Opfattelsen af moralen som en del af de evige 
sandheder peger netop på dens »naturgroethed «. En socialistisk moral derimod må være socialisters bevidste konstruktion. Som sådan kender vi den allerede fra de utallige påbud der flyder i en lind strøm fra de forskellige organisationer og partier i form af erklæringer, proklamationer, programmer, osv. Men vi ved også, at disse »socialistiske « moralske påbud slet ikke har den effekt på vore handlinger, som vor indbyggede borgerlige moral har.

THN søger at sammenkæde den socialistiske moral og strategi og skriver: »Enhver socialistisk strategi er i sit udgangspunkt tvunget til at møde magten på det terræn, hvor den er etableret: dvs. som statslig løsrevethed, fortættet i staten...« (s. 21) og han ser følgende problem: »Men dermed kommer en socialistisk strategi også tæt på det dilemma, der er etableret af den borgerlige magtform selv: at forblive fanget i statsraisonens magtlogik - eller at synke ned $i$ magtløshedens utopi«. (s. 21)

Jeg mener (sammen med en hel tradition i arbejderbevægelserne), at dette dilemma ikke er så tvingende som THN søger at gøre det. Den »statslige løsrevethed « og dens magtlogik er en fetisch - ikke i den betydning, at den ikke virkelig eksisterer, men i den betydning, at den ikke eksisterer uafhængigt af sit sociale grundlag. Analogt til THN opfattelse hed det engang på venstrefløjen: »Magten vokser ud af et geværløb « - men det er jo ikke rigtigt, magten vokser ud af kontrollen med de mennesker, der vil bruge geværerne. Det er ikke geværerne der skyder og det er ikke »staten« der handler. Opgøret med »magten « behøver altså ikke nødvendigvis tage form af magtkamp, men kan tage form af indvirken på magtens sociale grundlag.

Dette problem om »magt « tages også op af Inge Henningsen i en artikel om »Magt og moral «. I modsætning til Torben Hviid Nielsen interesserer hun sig ikke for at opstille »strategier«, men diskuterer problemet ud fra de involveredes perspektiv. Hendes centrale tese lyder: »Hvis jeg i denne situation skulle opstille normer omkring magt og moral ville jeg sige: Det mest umoralske er de undertryktes accept af magten. Man kan være tvunget til at affinde sig med den, fordi magt er magt; men det er umoralsk at acceptere den «.

Tanken er en god provokation af den gængse magttænkning. Samtidig peger den på mange venstrefløjsorganisationers og -personers paternalistiske indstilling overfor andre mennesker: Når f.ex. bestemte arbejdergrupper handler politisk reaktionært, udlægges det ikke som resultat af deres bevidste vilje, men enten som resultat af uvidenhed eller borgerlig løgnepropaganda - som bærere af en medfødt socialisme fraskrives de retten til at være moralsk ansvarlige og kan følgelig heller ikke kritiseres.

Inge Henningsen gør - med henvisning til herskende praksisformer på venstrefløjen - op med den opfattelse, at man ikke kan adskille mål 
og midler. »De midler der tages i anvendelse har ingen relation til de angivelige mål. Det man derimod trygt kan slå fast er, at man ikke kan skille midlerne og resultatet «. (s. 27) Det må være resultaterne der tæller og ikke en eller anden ideal målsætning, som de dækkes ind under. En accept af sådanne forklaringer betegner hun som »afmagtens umoral «. Istedet for denne accept må vi vende os imod denne vor egen umoral. Og hendes konklusion på forholdet til magthaverne, »borgerskabet «, er præcis den modsatte af Torben Hviid Nielsens: »Det er spild af tid specielt at diskutere magthavernes moral «. (s. 28)

Man finder en snert af denne afmagtens umoral i Anni Papes artikel om »Tvind og moralismen«, som er en omtale af en kritisk antologi om Tvind-skolernes virksomhed. Emnet er oplagt, Tvindskolerne ligner den laboratoriesituation alle borgerlige samfundsvidenskabsmænd drømmer om, når de skal undersøge social adfærd, samtidigt med at »moralske imperativer « dér har den dominerende adfærdsregulerende status.

Anni Pape stiller ganske vist problemet på samme måde som Inge Henningsen, dvs. retter opmærksomheden mod accepten og underkastelsen, når hun spørger: ».... hvad er det for strukturer som $g \varnothing r$, at folk frivilligt accepterer at underlægge sig dette vanvid i den bedste del af deres pure ungdom«. (s. 64) Men hun får af flere grunde ikke besvaret spørgsmålet særlig godt.
Først og fremmest fordi hun falder tilbage i den gængse moraliserende kritikform af »magthaverne « $\mathrm{i}$ stil med: »... formålet på højskolen er ikke at lære 'den globale virkelighed' at kende til bunds, men mere en personlighedsudslettende opdragelsesproces under en diffus kollektiv tvang «. (s. 63) Samtidigt gøres Tvind for meget til en ond sammensværgelse og deltagerne reduceres til $\gg . .$. offer for dette autoritære spil«. At gøre sig selv til »offer«, når man vil analysere sin egen politiske udvikling fjerner på forhånd mulighederne for at lære noget af den. Desuden opereres der med så »store « kategorier, at de i stedet for analyse blot fremstår som dårlige abstraktioner, som når f.ex. Tvind beskrives som »patriarkalsk «. Således skriver Anni Pape: ».... samtlige af de mange veteraner (dvs. lærerne på Tvind) som optræder som slagterhunde på fællesmøderne i bogen er netop kvinder! Det er i sig selv interessant, hvordan et pædagogisk eksperiment som Tvind, som i sit fundament er så mandsdomineret og patriarkalsk som noget $\mathrm{i}$ den grad kan administreres af kvinder «. (s. 65) Hvorledes skal virkeligheden nogensinde kunne af- eller bekræfte ovenstående påstand om »mandsdominans «, og dermed åbne for en mere adækvat diagnose af problemerne? Istedet for denne slags definitorisk sande konstruktioner, er der brug for analyser, der nærmer sig de processer og fænomener der virkelig finder sted. 
Tilsvarende uhåndterlige kategorier anvender Anni Pape, når hun i et rids af sin egen udvikling på Tvind binder forklaringen op på kategorien »identitet«. Identitet var noget hun i forskellige situationer valgte, ligesom man i den borgerlige sociologi (og ikke ret mange andre steder) vælger »roller«.

En analyse af Tvind er utvivlsomt lærerig, men den må så forankres i en mere omfattende teori om erfarings- og bevidsthedsdannelse, altså en »historisk materialisme« som også medtænker moralens betydning, og ikke blot er et forsøg på i moraliserende-psykologiserende termer at identificere Tvind med alskens dårligdomme. Der må jo også være noget andet der gør, at man nu snart må have passeret de første 10.000 deltagere på Tvind?

Tvind projekterne er som en integreret del af det eksisterende samfund - og den eksisterende venstrefløj - også bærer af dette samfunds modsigelser, og således et langt mere kompliceret fænomen. Snarere end at reducere Tvind til et reservat for en særlig patriarkalsk ondskab bør det analyseres som prototypisk eksempel på problemer i dannelsen af politisk bevidsthed og identitet og politisk praksis i dagens Danmark. I dette perspektiv bliver problemet at forklare, hvad det er i $»$ venstrefløjens « samfundsmæssige situation der begrunder, at autoritære ideologier, organisations- og socialismeopfattelser (som f.eks. »Leninisme«) stadig kan have tiltrækningskraft.

\section{Moralens årti?}

Temaet moral blev valgt på grund af emnets påtrængende aktualitet, hed det $\mathrm{i}$ den redaktionelle indledning. Denne påstand står imidlertid efter en læsning af nummeret helt ubegrundet - og er da også hentet fra en leder i dagbladet »Information «, grossist i den slags udnævnelser.

Selvfølgelig kan der siges noget vigtigt om moral, også i 80'erne, og selvfølgelig er venstrefløjens mere professionelle essayister (Hviid Nielsen, Bonde Jensen, etc.) altid klar med rimelig godt håndværk - men brænder de for sagen, vil de virkelig sige os noget med det de skriver?

Lederartiklens programmatiske udsagn (som f.ex. »Hvis vi undlader at demonstrere i praksis, at vi vil et andet liv, har vi først og fremmest svigtet os selv. Og så er der al mulig grund til at generationen under 25 kun siger 'nå' og svigter os «) virker på baggrund af numret som helhed lidt uægte, floskuløse. HUG's tendens til moraliseren uden egentligt moralsk budskab, skaber vel netop den frustration hos læseren som de selv verbalt advarer imod. Når de skriver: »Hvis vi ikke i vores kamp for et andet samfund har en etisk ballast og tager udgangspunkt $i$ et valg af værdier, frihed, moral, pluralisme, vil vi kunne legitimere alle former for diktatur «, (s. 9) er det ganske vist i rigtigt, men ensidigt. Kun gennem en erkendelse af værdiernes, frihedens, moralens, pluralismens, - der jo ikke er »evige sandheder «, men momenter af en specifik samfunds- 
form - konstitutionsgrundlag, kan man virkelig »vælge« og opstille alternativer. Uden denne begriben vil i socialistisk perspektiv en sådan åbenhed gøre alle værdier vilkårlige.

Erkendelsen af moralens, etc. konstitutionsgrundlag, det er netop den marxistiske teoris, »den historiske materialismes «, altså KRITIKKENS privilegium. Men karakteristisk nok stiller ikke en eneste af artiklerne i HUG deres problem som en kritik af moralen - i sidste ende betingelsen for at angribe moralske problemer andet end moraliserende. Et aspekt af kritikken af Kurasjeartiklen var at den ikke kunne gribe ind i de dimensioner hvori verden erfares, eller om man vil i hverdagsbevidsthedens tankeformer. Problemet med HUG forekommer teoretisk og politisk at være det modsatte, her kan man ikke bryde med disse tankeformer. Marxismens politiske betydning skulle i denne sammenhæng netop bestå $\mathrm{i}$ både at kunne nå frem til disse tankeformer, men også kritisk at overskride dem.

\section{Göran Therborn: The Ideology of Power and the Power of Ideology.}

\section{(London, NLB, 1980).}

I den historiske materialisme der blev præsenteret af Andreassen m.fl. var et af hovedproblemerne, at på trods af erklæringer om det modsatte - »historien « blev reduceret til pris-bevægelser og de fænomener, (såsom politik og ideologi, de handlingsformidlende momenter) som analysens af kapitalens bevægelser skulle bidrage til en forståelse af, opfattedes som tilintetgjort af denne analyse og forsvandt ganske enkelt, kun efterladende sig nogle »resultater«. I modsætning hertil var et problem i HUG, at ideologisk-politiske problemstillinger ikke lod sig forbinde med en analyse af historiske tendenser i den samfundsmæssige udvikling og dermed ikke kunne sætte sig ud over en moralfilosofis begrænsninger. I dette perspektiv udtrykker begge skrifter altså to sider af samme problem, nemlig den historiske materialismes grundproblem, om forholdet mellem samfundsmæssig væren og bevidsthed. Eller i den klassiske - men uklare og problematiske- metafor: forholdet mellem basis og overbygning.

Det forekommer derfor relevant at se på ovennævnte bog af G. Therborn, ${ }^{17}$ der på basis af den historiske materialisme bl.a. vil tage følgende problem op: »... jeg tror spørgsmålet rejst af Marx om den materielle determination af ideologier må konfronteres explicit, og ikke (som nutidige marxister har tenderet at fo- 
retrække) forbigås i forlegen tavshed, eller simpelthen gentaget, fortolket og genfortolket i en endeløs række af marxologiske exegeser. Hvad der er fors $\varnothing \mathrm{gt}$ her er en ny formulering af en teori om materiel determination og om klasse ideologier.« (s VIII). Jeg koncentrerer mig i det følgende kun om de dele af bogen der direkte indeholder antagelser om denne materielle determination og lader de $\varnothing$ vrige dele ufortalt.

»The ideology of power« er i princippet en elaborering og en delvis kritik af L. Althussers artikel om ideologiske statsapparater ${ }^{18}$. Imidlertid påpeger Therborn selv, at netop problematikken om den materielle determination er fraværende hos Althusser, og det er således her en evt. videreudvikling i forhold til forbilledet først og fremmest skal søges.

Bogen er vanskelig at karakterisere, da den hverken er en konkret analyse af bestemte ideologiske figurer og processer eller tager udgangspunkt $i$ en eksplicit kritik af andres forsøg herpå. Therborns mål er ».. at udvikle nogle analytiske begreber og forslag til forklaringer om ideologiens virksomhed i magtrelationer og social forandring.« (s. 1). Dette sker imidlertid i en form der gør en indholdsmæssig stillingtagen ret vanskelig, idet overvejelserne er holdt i yderst vage og generelle formuleringer. Desuden består forslagene til »forklaring « ofte i ret indviklede klassifikationer og opdelinger, der som regel igen mere eller mindre tilbagekaldes, idet det gøres klart, at disse klassifikationer ikke svarer til den virkelighed, de skulle belyse.

Da Therborn arbejder indenfor rammerne af en »dia-mat « opfattelse, betyder det, at hans »analytiske begreber « skal have gyldighed for alle produktionsmåder, hvilket på forhånd afskærer muligheden for, at overvejelserne bliver til ret meget andet end yderst generalliserede almindeligheder. Der er til gengæld lagt et stort arbejde $\mathrm{i}$ at formulere disse, så de - i første omgang - tager sig ud som noget helt andet.

Videnskabsteoretisk forekommer disse begrebers status også uklar, såvel i deres forhold til specifikke historiske samfund som til den »historiske materialismes « $\varnothing$ vrige begrebsapparat - hvad er eksempelvis deres relation til økonomikritikkens formbestemmelser? Blot at se dem som »hypoteser« er ikke foreneligt med deres generalliserede formulering. I denne sammenhæng er det påfaldende, at skønt Therborn selv påpeger, at der er mange mulige indfaldsveje til det næsten uudtømmelige emne ideologi, begrunder han faktisk ikke sit eget valg af en »overhistorisk « indfaldsvinkel.

\section{Ideologiens dialektiske karakter.}

Ideologibegrebet hører til blandt socialvidenskabernes mest mangetydige begreber og Therborn definerer det ualmindelig bredt som $\gg .$. det aspekt af den menneskelige betingelse under hvilket menneskelige væsener lever deres liv som bevidste aktører i en verden, der har mening 
for dem i forskellige grader. Ideologi er det medium gennem hvilket denne bevidsthed og meningsfuldhed virker«. (s. 2). Ideologi defineres altså her ikke indholdsmæssigt - f.eks. som »falsk bevidsthed «, og denne »brede« definition $g \varnothing r$ det vanskeligt at finde samfundsmæssige bevidsthedsformer, der ikke er ideologi i ovennævnte betydning, ligesom den er bestemmende for, hvilke problemer der overhovedet kan stilles i behandlingen af emnet.

Lidt uventet argumenterer Therborn for at ideologien skulle besidde en dialektisk karakter: »Al ideologis dialektiske karakter kan ses som antydet af de modstillede betydninger af det samme ord »subject « (på engelsk) i udtrykkene - 'the subject of King X (or the social order Y) og 'the subjects of history' « (s. 16). »Ideologier underkaster (subject) ikke blot folk under en given orden. De kvalificerer dem også til bevidst social handling, omfattende handlinger medførende gradvis eller revolutionær forandring. Ideologier fungerer ikke bare som 'social cement' «. (s. VII).

Denne centrale tese om ideologiens dobbelte funktion (kvalifikation/ underkastelse), der skal konstituere dens dialektiske karakter, er en følge af den ovennævnte definition af ideologi. Når man slår vidt forskellige $\gg$ samfundsmæssige bevidsthedsformer « (Marx) sammen under det fælles overgreb »ideologi«, er det jo ikke mærkeligt, at man kan konstatere »modsigelser « mellem de forskel- lige sociale funktionssammenhænge, hvori de indgår (f.eks. klassebevidsthed og pengefetischisme) - men at en specifik ideologi dermed i sig selv skulle besidde »dialektisk karakter « kan Therborns argumentation ikke overbevise om.

I forlængelse af Althusser argumenterer Therborn for at ideologiens grundlæggende funktion er konstitutionen af subjektivitet, (forvandlingen af individet til subjekt) hhv. »subjektivitetsformer « og han uddyber sit begreb om subjektivitetsformer gennem en kritisk jævnføring med borgerlig sociologis rolleteori. Rolleteorien må forkastes, da den ikke ser konsekvensen af den dobbelte betydning af »subjekt« og derfor er »dybt ikkedialektisk «. Derimod fremhæver problematikken om subjektivitet og subjektivitetsformer $\gg .$. den indre enhed $o g$ mulige konflikt af de modsatte processer af underkastelse (subjection) og kvalifikation« (s. 22).

Therborn vil gøre op med marxismens/Althussers skarpe modstilling af videnskab-ideologi, ${ }^{19}$ fordi den har været forbundet til en forståelse af menneskelig motivation, som han finde uholdbar. »Menneskelig adfærd var determineret af 'interesser', af klasseinteresser. Bevidsthedens former korresponderede enten med disse 'interesser', eller også gjorde de ikke, i såfald var de illusioner og som sådan ineffektive (i det mindste i det lange løb). ... Denne opfattelse af motivation gennem interesser antager, at normative opfattelser af 
hvad der er godt og dårligt og opfattelser af, hvad der er muligt og umuligt er givet $i$ og med realiteten af det værende og kun er tilgængelig gennem sand viden om det værende." (s. 4).

Da udbytning ikke automatisk skaber en 'interesse' i sin ophævelse eller automatisk fremkalder modstand, stiller han problemet således: Hvordan konstitueres klasser som menneskelige kræfter i kamp?

Det er til en vis grad en relevant kritik af marxismen, at den ikke har beskæftiget sig meget med den ideologiske konstituering af kæmpende klassesubjekter og istedet er faldet tilbage på et postulat om, at en sådan konstituering fulgte automatisk af de 'objektive' interesser. Men spørgsmålet er, om miseren skal lokaliseres i inddragelsen af interesser som forklaringsfaktor, sådan som Therborn mener - eller om det ikke snarer drejer sig om, at han selv arbejder med et unødvendigt forkortet og utilstrækkeligt (normativt) begreb om interesser: »Men 'interesser' i sig selv forklarer ingenting. 'Interesser' er et normativt begreb der indicerer den mest rationelle handlingskurs i et prædefineret spil, dvs. i en situation i hvilken tab og gevinst allerede er defineret. Det problem der imidlertid skal forklares, er hvorledes medlemmer af forskellige klasser bringes til at definere verden og deres egen situation og muligheder i den på en specifik måde.« (s. 10).

Hvordan det end forholder sig med interesserne, ${ }^{20}$ er det helt sik- kert, at den aktuelle marxisme ikke har mange bud på en teori om, hvordan forskellige sociale grupper definerer verden, deres egen situation og dens muligheder - så for såvidt er der ingen tvivl om, at Therborn peger på en vigtig og relevant problematik.

\section{Materiel determination?}

I forsøget på at besvare bestemte teoretiske problemstillinger, må disse selv undersøges og evt. reformuleres, (»at stille problemet rigtigt, er at besvare det «). Men i Therborns formulering virker det ikke som marxismens klassiske problemstillinger omkring ideologi er blevet reformuleret, men snarere som om de - delvist ihvertfald - er blevet udskiftet. ${ }^{21}$ Fra i den klassiske formulering at fokusere på mulighedsbetingelserne for et »brud « mellem ideologi og revolutionær klassebevidsthed, bliver ideologien af Therborn hovedsageligt betragtet i sin virksomhed indenfor reproduktionen af givne samfund. Dette skift i fokusering følger også af den »overhistoriske« betragtningsmåde, der ikke muliggør andre bestemmelser af revolutionære overgange fra én samfundsform til en anden, en de kendte, men forholdsvis tomme udsagn om tilspidsningen af modsigelserne mellem produktionsforhold og produktivkræfter. »Klassebevidsthedsdiskussionen " derimod, henter sit indhold specifikt i den proletariske revolutions problemer. Therborns egentlige interesser forekommer således at ligge nærmere den nyere fænemonologisk 
orienterede sociologis diskussion af »hverdagsbevidsthed « end marxismens klassiske problemstillinger.

I forsøget på at nå til en »sikker og systematisk « forståelse af hvad der determinerer frembringelsen og artikulationen af ideologier, vil Therborn tegne et strukturelt kort over ideologiernes univers som helhed. Til dette formål laver han et skema indeholdende 4 hovedtyper af ideologi og understreger, at hans inddeling er rent analytisk, og altså drejer sig om samtidigt eksisterende dimensioner i subjektivitetens konstitution. Samtidig påstås det dog, at disse 4 typer er »udtømmende og irreducible«. Dette irreducible har som konsekvens, at det ideologiske univers aldrig er reducerbart til klasseideologier, da disse kun udgør en eller to af de 4 dimensioner, samt at et afgørende aspekt af ideologisk kamp og styrkeforhold er en given ideologis artikulation i sammenhæng med andre.

»Spørgsmålet om den materielle determination af ideologi er central for historisk materialisme. ... I den klassiske tradition blev dette spørgsmål taget op ved hjælp af 'basissuperstruktur'-metaforen.

Men i den aktuelle Vestlige Marxisme har ikke blot metaforen, men selve spørgsmålet tenderet mod at blive skudt til side.« (s. 31). En diskussion af problemstillingen vil derfor altid implicere en forholden sig til basis-overbygningsmetaforen. Therborn fremsætter først 2 generelle »forslag « om determinationen af et givet ideologisk system. Det første drejer sig om, at ideologier kun eksisterer i historiske former og det andet om, at »alle ideologier virker $i$ en materiel matrix af affirmationer og sanktioner og denne matrix determinerer deres indbyrdes relationer.« (s. 33). Til belysning af hvad dette vil sige hedder det eksempelvis, at en bestemt religions sejr over andre ideologier altid involverer sociale kampe. »Derfor er den mest umiddelbare determinant $\mathrm{i}$ affirmeringen af en bestemt religion og sanktioneringen af dens rivaler den overlegne verdslige styrke hos de sociale kræfte til hvilke den er knyttet.«(s. 36)!!

Hvis man accepterer den historiske materialismes basale læresætninger, må der tilføjes endnu to »forslag « til de ovennævnte. Dels: »alle ideologier eksisterer i historiske former af artikulation med forskellige klasser og klasse ideologier« (s. 38). Når det imidlertid skal uddybes hvad dette »eksisterer med « egentlig betyder, bliver det til helt vage bestemmelser: de forskellige ideologier $\gg . .$. are bound up with and affected by different modes of class existence and are linked to and affected by different class ideologies.« (ibid).

Det sidste »forslag « går på, at struktureringen af et givet sæt af ideologier altså såvel klasse som ikke-klasse ideologier - er »overdetermineret « af klassernes styrkeforhold og af klassekampen, idet også ikke-klasse ideologierne er »bundet « til klasser og ».. alle ideologier er indskrevet $i$ et overordnet system af 
social magt konstitueret af klasser med varierende styrke som er i konflikt.« (s. 39). Man kan sige at dette er en »logisk « følge af det foregående, da ideologiernes $»$ affirmerende og sanktionerende matrix « jo består af de $\varnothing$ konomiske og politiske magtrelationer, der netop i og med deres eksistens udtrykker et givent klasseherredømme. Uklarheden består i, at ideologierne på den ene side var medkonstituerende for den $»$ materielle matrix «, mens på den anden side ændringerne i denne matrix skulle forklare ændringer i ideologierne, men uden at den forklaringstype, der tilbydes, kan dække så komplicerede forhold. Man får nærmest det indtryk, at Therborn, når det kommer til stykket, arbejder med en meget grov basisoverbygning forklaringsmodel og at hans anstrengelser går ud på at modificere og relativere den, ikke at udarbejde en anden forklaringstype. ${ }^{22}$ Hvad »overdeterninationen iøvrigt betyder, om den har konsekvenser i og for ideologien, fremgår imidlertid slet ikke.

Therborn vurderer selv sine forslag således: »De fire forslag stillet ovenfor har ikke samme teoretiske status. Min egen opfattelse er at de første to, der drejer sig om historiciteten og den determinerende materielle matrix for alle ideologier, er fundamentale for ethvert videnskabelige studie af ideologiers funktion. Det tredie, at i klassesamfund er alle ideologier på forskellig vis forbundet med forskellige klasser, er en umådelig frugtbar guide til forsk- ning og forståelse, som aldrig burde glemmes; medens det sidste forslag strukturen af de ideologiske system er overdetermineret af klassekampen - måske burde behandles som en meget vigtig og frugtbar hypotese, hvis forklarende kraft bliver et åbent spørgsmål i enhver given empirisk unders $\varnothing$ gelse.«(s. 40).

Dernæst behandles determinationen af ideologien videre under overskriften $»$ Frembringelsen (generation) af ideologier og materiel forandring " og her fremsættes nu 8 »forslag «, hvoraf dog kun de 3 basale skal refereres:

$\gg$ Forslag et: Frembringelsen af ideologier i menneskelige samfund er altid, fra synspunktet hos socialvidenskab og historie, en proces af forandring af præ-eksisterende ideologier.

Forslag to: Den ideologiske forandring og frembringelsen af ideologier, er altid afhængig af ikkeideologisk, materiel forandring.

Forslag tre; Den vigtigste materielle ændring er konstitueret af samfundets indre sociale dynamikker og deres produktionsmåder.« (s. 41). Som det fremgår er disse teser så generelt formulerede, at de næsten ingenting siger, og det er svært at vide, hvad man skal stille op med dem. Det er yderst få af overvejelserne, der kan præcisere forståelsen af »ideologiske « forhold i det aktuelle kapitalistiske samfund og således være til gavn i f. eks. den foregående diskussion om moralens aktuelle problemstillinger. 
Det hænger for mig at se sammen med selve den metodisk-teoretiske indfaldsvinkel, forsøget på at komme med »analytiske« forklaringer, der skal have gyldighed på tværs af de forskellige samfundsformer, samtidig med at de fænomener, der skal begribes defineres så bredt, at de mister enhver specificitet.

Spørgsmålet rejser sig her, om denne marxisme/historiske materialisme egentlig har noget til fælles med de grundlæggende træk og intentioner i Marx' metode. I et for ideologi-teorien centralt citat $i$ »Kapitalen « hedder det: »Det er i realiteten langt lettere gennem analyse at finde de religiøse tågedannelsers jordiske kerne, end omvendt at udvikle de himmelgjorte former af de respektive virkelige livsforhold. Men det sidste er den eneste materialistiske og derfor videnskabelige metode.« (Bd 1, s. 393/547). Her gives ihvertfald to metodiske anvisninger, der bryder med Therborns fremgangsmåde: 1) der må tages udgangspunkt i en historisk specifik samfundsform, som jo er den eneste form hvori »virkelige livsforhold « kan foreligge, 2) »ideologierne «skal ikke »tilbageføres« til deres sociale grundlag, men »udvikles « ud fra det.

Hermed er selvfølgelig ikke sagt noget om hvordan denne »udvikling « skal foregå - blot peget på, at når Therborn siger: »Jeg vil derfor tage Marx' indsigter som udgangspunkt for et fors $\emptyset \mathrm{g}$ på en mere systematisk teori« (s. 41), er det faktisk ikke, hvad han gør. Det centrale metodis- ke spørgsmål til Therborns angrebsmåde er : hvilken forståelse af kritik lader sig forbinde med hans tilgang. Dette spørgsmål stiller han imidlertid ikke selv - tilsyneladende er den marxske teoris kritisk/revolutionære moment fortrængt af programmet om materialisme/videnskab.

\section{Klasseideologi og klassebevidsthed.}

Selvom der som nævnt er sket en forskydning i forhold til den klassiske diskussions problemstillinger, betyder det ikke, at klasseideologi og -bevidsthed slet ikke tages op hos Therborn. Klasseideologi skal analyseres under to aspekter, »egoideologier « (der former klassesubjektiviteten selv) og »alter-ideologier « (der angiver forholdet til andre klassesubjekter). »Fra den ideologiske konstitution af klassekamps-subjekters standpunkt, er det afgørende aspekt af alterideologien i de udbyttende klassers tilfælde, rationalet for deres beherskelse af andre klasser, i de udbyttede klassers tilfælde er det basis for deres modstand mod udbytterne.« (s. 61). Dette implicerer imidlertid ikke, at der er noget $\mathrm{i}$ arbejderklassens klasseideologi, der peger på en overskridelse af kapitalismen, fordi heller ikke klassekampen overskrider den form for udbytning og beherskelse, på hvilken den er baseret og indenfor hvilken den virker. Therborn kan derfor i forlængelse af Kautsky - Lenin påstå: »... der kan ikke logisk argumenteres for, at en socialistisk ideologi - en ideologi ifølge hvilken et socialisti- 
sk samfund både er godt og muligt at opnå - er implicit i arbejdsklasseeksistensen og derfor udgør dele af arbejderklasse ideologien.« (s.65) selvom en kraftig »affinitet « gør sig gældende mellem arbejderklassen og socialistisk ideologi.

Til karakteriseringen af denne opfattelse hører desuden opfattelsen af revolution og socialisme. Revolution tænkes som en »objektivistisk « udgave af modsigelsen mellem produktionsforhold og produktivkræfter (se s. 47) (der jo også er den eneste mulige »overhistoriske « revolutionsopfattelse): »Hvad der fører til social revolution er den modsigelsesfulde og opløsende (disarticulating) dynamik i en given produktionsmåde; en sådan revolution er produkt af klassekamp under ændrede parametre, der følger af netop denne dynamik.« (s. 65). Socialismen er så »... en projektion ind $i$ et fremtidigt samfund og en specifikation inden for en politisk strategi af alle de centrale elementer i arbejderklasse-ideologien...«(s. 66).

Med disse argumenter er synspunktet om den udefra tilførte revolutionære bevidsthed indirekte fremsat, med hvad deraf følger af leninismens tradtionelle politikforståelse. Følgelig må der da også gøres op med den unge G. Lukacs' opfattelse af klassebevidsthed, - der netop udleder den af klassens egen samfundsmæssige aktivitet - som i Therborns udlægning kommer til at høre til »den normative politiske filosofis verden «. Dette sker imidlertid gennem en argumentation, der er fuldstændig udvendig i forhold til Lukacs'. Således afvises hans begreb om klassebevidsthed - der bevidst var udformet som modbegreb til arbejdernes empiriske bevidsthed fordi det ikke var udviklet som redskab til empirisk analyse.

I Therborns 1970-kritik af Frankfurterskolen hed det: »Effekten af de kombinerede faktorer af formel bevarelse af teorien, fornem individualisering og akademisk integration er en kumultativ mystifikation. Denne formel frembringer en legitimation for en ren ideologisk radikalisme, selvtilfreds installeret i den hyggelige akademiske institution, ikke engang med en indirekte relation til politik som den erfares af masserne, men stadig forædlende en kritisk teori, der går tilbage til en fortolkning af Marx «. (s. 109). Godt 10 år senere forekommer det at være en præcis og aktuel selvkritik - måske bortset fra, at fortolkningerne ikke er begrænset til Marx' værker. Af hans gamle krav: »Det er afgørende at bevæge sig fra opdagelsen af kapitalismens rædsler til et forsøg på at forstå den videnskabeligt og til at forene sig med masserne for at omvælte den«. (op. cit. s. 120) - står nu kun Therborns krav om »videnskabelige forståelse« tilbage.

Selvom man må irriteres over den selvhøjtidelige og indviklede facon hvormed Therborn fremsætter sine - i en række tilfælde ret banale og intetsigende - teser, er der alligevel blevet peget på grundlæggende problemer omkring bestemmelsen 
af »socialisme « som mål i en social bevægelse under kapitalismen. Dette problem blev angrebet under et andet synspunkt i diskussionen af HUG!, nemlig som problemet om $»$ socialistisk moral «.

Problemet drejer sig om de normative elementer i vore forskellige socialisme opfattelser. Ikke fordi disse elementer kan eller skal fordrives, men fordi det er vigtig, at udsagn der faktisk er normative - dvs. har deres udspring i den eksisterende samfundsform - ikke underhånden slæbes med som selvklare og uproblematiserbare forudsætninger i diskussionen af hvordan vi vil skabe »socialisme $\ll .{ }^{23}$

Man kan her groft stille to opfattelser overfor hinanden, den ene siger at socialismen er en nødvendig (lovmæssig) følge af kapitalismens objektive udvikling, den anden, at den er et moralsk/bevidsthedsmæssigt spørgsmål. Therborn siger snarere det første end det sidste: »Muligheden for en revolutionær ændring burde afledes af sandsynligheden af økonomiske og politiske kriser og fra eksistensen af materielt organiserede alternativer, snarere end fra sindstilstanden hos en klasse.« (s. 111).

$\mathrm{Nu}$ uddybes det ikke hvad »materielt organiserede alternativer «skal betyde. Og det er netop en mangel, der er fælles for alle de 3 skrifter, der her er taget op: De interesserer sig ikke for hvad den aktuelle kapitalisme har produceret af »alternativer « såvel i »materiel« som »normativ« henseende. Marxismen insisterer jo netop programatisk på, at »socialisme« ikke bare er en god ide (blandt mange andre), men at den har bestemt, specifikke forudsætninger eller mulighedsbetingelser (objektive og subjektive), som menneskene historisk må producere. Socialismen er ikke identisk med eller en »logisk « følge af disse betingelser, men et projekt (med hvad det indebærer af muligheder for fejlslag) der først bliver muligt på grundlag af dem. $\mathrm{Og}$ bør det følgelig ikke være marxismens centrale opgave (erkendelsesledende politiske mål) - uanset om den analyserer »statslig krisepolitik « eller »moral « - at søge at afdække disse forudsætninger og påpege deres praktiske mulighed for anderledes-væren og derigennem åbne for diskussionen af de principper, vi vil tilstræbe i udformningen af denne anderledesværen - dvs. åbne for diskussion af »konkrete utopier «?

\section{Marxismens krise?}

Der snakkes for tiden meget om, at marxismen er i krise. hvis det skal have nogen mening, må det betyde, at marxismen som en specifik teoriform er stødt på sine egne grænser og derfor ikke er i stand til på adækvat måde at begribe de fænomener, den udpeger som sit teoretiske objekt. Skal man slutte noget ud fra de eksempler på forskellige former for aktuel marxisme, der er kommenteret $\mathrm{i}$ det foregående, ses ingen krisetegn i ovennævnte betydning. For såvidt denne marxisme ikke fore- 
kommer god nok, har det ikke være begrundet $i$, at denne særlige teoriforms muligheder var udtømte - men derimod i, at de ikke var udnyttede. Betegnelsen »marxismens krise« vil i en sådan sammenhæng blot tjene til at skyde bestemte problemer ind under overpersonlige, uhåndgribelige sammenhænge - problemer som faktisk drejer sig om former for politisk engagement og aktivitet.

Fællestræk ved den her diskuterede marxisme er en fraværende reflektion over en revolutionær erkendelsesinteresses konsekvenser, der teoretisk kommer til udtryk i en opgivelse af marxismen som kritik. Kritikken - som afdækningen af det nye samfunds mulighed i det gamle samfunds skød - er erstattet af en »videnskabelighed «(den være sig så god og åben den være vil) som ikke formår at demonstrere denne mulighed og i denne betydning ikke trænger frem til virkeligheden.

Der er sikkert mange - og materielle! - grunde til denne begyndende ændring af marxismen. Ændringen i sig selv er imidlertid ikke kun problematisk, den udtrykker også marxismens praktisk involvering $\mathrm{i}$ det eksisterende samfunds processer. Denne slags periodiske ændringer og omformninger bliver først en trussel mod teoriens egentlige politiske intention, hvis de ikke længere betragtes som en afprøvet mulighed, der skal læres af, en risiko der er løbet, og hvis resultater må evalueres. Alternativet, selvtilstrækkelig videnskabelighed, bør ikke være marxismens anliggende.

1. Med »historisk materialisme« henvises her altså ikke til en bestemt teoriretning indenfor marxismen, men snarere til en intension, der er fælles for en lang række teoretisk og metodisk helt uforenelige opfattelser. At en sådan orientering mod bredere samfundsteoretiske problemstillinger ikke er et specielt dansk fænomen, samt at en sådan nyorientering må indebære forskellige grader af revision af hidtidige »skoler « og »positioner « skulle være klart nok. Jvf. hertil indledningen til »Theorien des Historischen Materialismus« hrsg. von Jaèggi/Honneth, Suhrkamp 1977.

2. Artikler fra denne gruppe:

Andreassen; Andreassen / Kerndrup / Kjær; Kjær - alle i Kurasje nr. 19/20.

Andreassen / Kjær; i Kurasje 21.

Andersen / Land / Thorsen/ Wolfsberg; Andreasssen / Kjær; i Kurasje 25.

Andreassen / Bahner / Elling / Kerndrup / Kjær i Kurasje 26.

Kjær i Kurasje 27.

3. Jvf. R. Jacobys diskussion af Korsch-Kautsky kontroversen: »Vulgærmarxisterne, under indflydelse af positivismen og naturvidenskaberne, ignorerede den dialektiske relation mellem bevidsthed og samfund og forvanskede som konsekvens heraf marxismen til social reformisme. Integreret i det borgerlige samfunds realitet er dets »geistige Struktur « og derfor er »geistige Aktion « integreret i den revolutionære proces. At ignorere disse momenter var at ignorere marxismens kerne ...« (Towards a critique of automatic marxism « i TELOS nr. 10) 
4. Denne tendens tages op i næste afsnit i diskussion af HUG!. Jvf. hertil P. Kaarsholms kommentar i Kultur \& Klasse 1981.

5. Se R. Jacoby: Det sociale hukommelsestab, Hans Retizel 1977. Det sociale hukommelsestabs effekt er fortrængningen af kritisk tænkning. »Den vitale forbindelse mellem tanke og hukommelse bliver dødbringende, mens glemsel og nyskabelse lever af hinanden og blomstrer«. (s. 155)

6. Denne tiltro til den videnskabelige fremstillings magiske evner er ingen isoleret lapsus, men gentages flere gange: Marx »... må nå frem til en fremstilling af de virkelige materielle forhold, og dermed overskride eller tilintetgøre filosofien og spekulationen«. (s. 27), eller »Derfor må kapitalismens udvikling fremstilles udfra kategoriernes struktur indenfor det moderne samfund. Først når det lykkes vil det spekulative og den abstrakte logik være tilintetgjort«. (s. 27) At det i forfattergruppens selvforståelse stort set kun er dem selv, der siden »Marx-Engels-Teorien « blev udtænkt, har været på sporet af denne »fremstilling « får dem ikke et $\varnothing j$ jeblik til at spekulere på om årsagerne til spekulationens, ideologiernes, filosofiens og den abstrakte logiks utrolige popularitet skulle kunne findes $\mathrm{i} »$ de virkelige, materielle forhold « - disse fixe ideer gøres blot til produkter af en forkert læsning af Kapitalen (jvf. f.ex. s. 23,31,32).

7. Jv.f Jacobys diskussion af Korschs synspunkter: »Særlig marxisterne, fuldstændig som de borgerlige tænkere, betragtede marxismens filosofiske indhold som lig nul. Korsch citerede Franz Mehring fra det Tyske Socialdemokrati, som erklærede 'forkastelsen af alle filosofiske fantasier'. Denne fornægtelse af al filosofi hvilede på en ikke-dialektisk fortolkning af Marx' sætning: 'Filosofi kan ikke ophæves uden at blive realiseret'. Snarere end at stemple alle former for bevidthed som ideologi og derefter ignorere dem, formulerede Marx kritik, der på en gang var kritik af produktionsrelationerne såvel som af 'specifikke sociale bevidsthedsformer' «. (op. cit. Telos 10, s. 120)

8. Et problem med dette citat er, at det er ligeså tvetydigt i originalen, som i den her gengivne oversættelse. Det er sprogligt uklart, om teoretikerne skal gøre sig til talerør (på tysk organ) for »proletaritatet « eller »for det, som foregår for øjene af dem « - hvilket jo langtfra kan være det samme (Parteilichkeitsproblem). Så vidt jeg kan se, læser Andreassen m.fl. citatet på den sidste måde - selv det er mig uklart, hvad det egentlig kan betyde.

9. Det skrift af Engels, som Andreassen m.fl. påkalder som sandhedsvidne for deres udlægning af forholdet mellem »logik og historie «, er den herostratisk berømte anmeldelse af Zur Kritik som efter Engels egen opfattelse er så ubehjælpsom, at selv Fru Marx (!) må dø af grin.

For en grundig diskussion af problemerne i forholdet mellem logik og historie, se den fremragende artikel af H.G. Basckhaus i Kurasje 27/28, 1981.

10. Af sammenhængen hos Engels fremgår det tydeligt, at han med »logisk « henviser til Hegels metode, dialektikken, sådan som den (efter Engels opfattelse) fremstår »renset « efter Marx' kritik. I denne sammenhæng er det endvidere oplysende, at Marx betegner A. Smith' og D. Ricardo' metode som »historisk og beskrivende metode « (MEW 4, s. 69) og Smith og Ricardo som deres epokes historikere (op. cit. s. 142).

11. Jeg mener selv dette er et forkert stillet problem, men det følger af forf. egen argumentation - deres opfattelse af forholdet mellem værdi og pris ligner det Backhaus i ovennævnte artikel karakteriserer som forholdet mellem $\varnothing$ llet og ølkruset.

12. Jvf. A. Arato/P. Breines: The young Lukacs and the origins of western marxism, Pluto press 1979, s. 213.

13. Sebastian Franck s. 63 - se nærmere note 15.

14. Helmut Fleischer: »Das handlende Subjekt im Histomat« i Sozialphilosopische Studien, Berlin 1973, s. 51.

15. Jvf. KURSCHBUCH nr. 60 fra juni 1980, der også er et temanummer om moral og hvorfra HUG! har hentet bidrag. Emnet er ellers ret forsømt i den socialistiske litteratur. En ret interessant og sympatisk behandling får problemet eksempelvis hos Otto Rühle-eleven Henry Jacoby, der under pseudonymet Sebastian Franck har skrevet bogen »Zur Kritik der politi- 
schen Moral « Giessen, 1972. Bogen er oprindelig skrevet i exil i 1939 og Jacoby er selv meget bevidst om den særlige betydning den politiske moral får, når man må leve som politisk flygtning. Bortset fra en tendens til meget håndfast omgang med almengyldige psykologiske følgeslutninger - der ligesom hos Rühle hovedsageligt stammer fra Alfred Adler - får emnet her faktisk en mere omfattende og mere direkte politisk behandling end i HUG! Om sin intention skriver Jacoby: »Den opgave vi har stillet os her, er at vise, at i en socialistisk arbejderbevægelses kampe spiller det politisk handlende menneskes forholden sig, i sammenhæng med de moralske principper der ligger til grund herfor, en vigtig rolle. At dette hidtil ikke eller knap nok er blevet erkendt forekommer os at være et led i katastrofens årsagskæde. Det er vor overbevisning, at nydannelsen [af arb. bev.] behøver en ny erkendelse og dermed en anden praksis.« (s. 20).

16. Et sted hedder det f.ex. »... skabelsen af et virkeligt socialistisk samfund forudsætter en revolutionering af behovene og livsstilen og en opbygning af nye fællesskabsformer. M.a.o. en understregning af moralens centrale betydning for en social revolution «. (s. 41), og et andet sted hedder det at moral »... i sidste ende er det samlende og principielle udtryk for den måde et liv leves på...«. (s. 55) Dette er ikke et forsøg på at være pedantisk, men dette HUG-nr. er i alle sine indlæg så generelt i formuleringerne, at det aldrig bliver rigtig klart hvilke elementer af virkeligheden der rent faktisk lader sig specificere som »moral«. Temaet kunne lige så godt have heddet »Ideologi«. Som eksempel på at det har praktiske konsekvenser, hvilke virkelige fænomener der henvises til med begrebet kan nævnes en artikel af Inge Henningsen, hvor der står: »Moralske påbud hjælper kun, hvis man kan sætte magt bag «. (s. 26) Er det imidlertid ikke sådan, at den normative regulering af adfærd er »dobbelt« - 1) som retslig regulering, der beror på ydre tvangsmagt, 2) som »inderliggjorte«/internaliserede normer, herunder moral, der for såvidt de beror på »ydre magt«, har denne form af »tvang til selvtvang«? For det praktiske revolutionære opgør med »moralen« er dens samfundsmæssige specifitet altså afgørende, idet 1) og 2) kræver hver sin form for praktisk opg ør.

17. Therborn repræsenterer - som indehaver af generalagenturet for den Althusserianske marxisme i Skandinavien - yderligere en marxismeopfattelse i forhold til de tidligere omtalte.

For en kritisk omtale Therborn senere produktion, se Allan Sicas artikkel i »Tekla«nr. 7, 1979.

18. Louis Althusser: Ideologi og idelogiske statsapparater, La. Pensee 151, 1970, her citeret efter en dansk piratoversættelse u.å.

19. Dene relativering af »videnskabens« status er et fremskridt i forhold til Therborns position i hans berygtede artikkel om Frankfurterskolen fra 1970 (NLR no. 63), der fremstår som et credo til en helt uproblematiseret »moderne videnskabelighed «som Frankfurterne med deres humanistiske filosofi altså forsynder sig imod.

20. Jürgen Ritsert har ( $\mathrm{i} »$ Denken und gesellschaftliche Wikrlichkeit 1 «, Arbeitsbuch zum klassischen Ideologibegriff. Frankfur/New York 1977) på en lang række helt centrale punkter en anden ideologi-teoretisk forståelse end Therborn, og han tillægger netop også interesserne en anden betydning, ligesom han også bestemmer dem anderledes (ikke til normantive momenter reducerbar). Bl.a. hedder det: »Stragegi, behov og situation er altså interessebegrebets hovedbestanddele, hvorved »Situation « i den materialistiske teori i almindelighed falder sammen med »materielle Lage«, en specifik placering i den totalsamfundsmæssige produktions og reproduktions objektive struktursammenhænge. Begrebet »Interesselage « kan have to betydninger: 1) position i den toralsamfundsmæssige reproduktionsproces, placering i en objektiv samfundsmæssig struktursammenhæng, 2) Udtryk for en særlig, empirisk forhåndenværende konstellation af strategie, udlægning og situation.«(s. 174).

21. Dette er da også hans intention, idet han vil »...udvikle en kritik af og et alternativ til de klassiske og stadigt fremherskende problematikker om magt/samtykke, legitimitet og sand og mystificeret bevidsthed.« (s. 93).

22. I sin diskussion af disse problemer griber J. Ritsert tilbage til F. Engels »vekselvirkningstese« med økonomien som »bestemmende i sidste instans« og stiller spørgsmålene: »Begrebet 
'vekselvirkning' (hhv. 'bestemmende') forbliver forpligtet overfor en - hvor bredt den end opfattes - forestilling om samfundsmæssig kausalitet. Er dette faktisk den forklaringsteoretiske grundlæggende henseende, hvori kritikken af den politiske $\varnothing$ konomi formulerer fremstillingsgangen eller i det mindste sammenhængs-udsagn? Og sammenhængende hermed: Hvis intentionalitet og orientering faktisk har en selvstændig betydning, er det så overhovedet holdbart at forklare forholdet mellem basis og overbygning så afgjort indenfor rammerne af (bredt opfattede) kausalitetsforestillinger? « (op. cit. s. 39)

Ritserts egne teser går på, at ideolgien må undersøges som særlig aspekt af totalsamfundsmæssig reproduktion og forandring, for kapitalismens vedkommende altså i sammenhæng med værdi - og merværditeorien, hvor begrebet »Erscheinung « får særlig betydning.

23. P. Kemp viser, at det han kalder Marx' personalogi (personen, er i sit væsen fri og må i det mindste besidde rådigheden over sine egne kræfter og evner) både er normativ forudsætning for fordømmelsen af kapitalismens udbytning og for det frihedsrige kommunismen skal realisere. Og han stiller spørgsmålet: »Men hvem siger, at det er rigtig, at ethvert menneske har ret til at nyde frugterne af sine produkter?«(P. Kemp: Nyt lys over Marx, Kbhvn. 1975, s. 52) 
LarsQvortrup:

KRISE, REVYLLTTON,

VTOPI 


\section{NYHED!}

\section{LARS QVORTRUP}

\section{KRISE, REVOLUTION OG UTOPI}

Kriseteori - det begreb har efterhånden fået en snæver, økonomisk og pessimistisk klang: konjunkturnedgang, underskud på betalingsbalancen, strukturproblemer...

Denne bog står på to måder i modsætning til den herskende »marxisme« på venstrefløjen.

Det er efterhånden - også på venstrefløjen - blevet et udbredt udsagn, at kapitalismen ikke nødvendigvis, dvs. på grund af indre lovmæssigheder, vil bryde sammen. Heroverfor fastholder bogen i en omhyggelig rekonstruktion af loven om profitratens faldende tendens og i en kritik af forskellige forvanskninger af denne lov, at og hvordan kapitalismen er en sammenbrudsmærket produktionsmåde.

Det er efterhånden blevet et udbredt udsagn, at Marx's kriseteori handler om $\varnothing$ konomi i snæver forstand. Heroverfor fastholder bogen, at kriseteorien er en omfattende og forhåbningsfuld teori om sociale forhold: om kapitalismens klassekampe, om oprør, revolutioner og contra-revolutioner og om utopierne om et bedre samfund.

Kapitalismen bryder ikke bare sammen. Den afsætter også utopier om det klasseløse samfund som frihedens rige og den skaber mulighederne for virkeliggørelsen af et sådant samfund.

BOGLADEPRIS: 69,- KR

PRIS SOM KURASJE-ABONNEMENT 54,- KR 


\section{KURASJE}

Løssalgspriser:

\begin{tabular}{|c|c|}
\hline Nr. 1 & udsolgt \\
\hline Nr. $2 / 3$ & udsolgt \\
\hline Nr. 4 & 20,0 kr. \\
\hline Nr. 5/6 & udsolgt \\
\hline Nr. 7 & udsolgt* \\
\hline Nr. 8 & $12,-\mathrm{kr}$. \\
\hline Nr. 9 & udsolgt \\
\hline Nr. 10 & 20,- kr. \\
\hline Nr. 11 & udsolgt \\
\hline Nr. 12 & udsolgt \\
\hline Nr. 13 & 30,- kr. \\
\hline Nr. 14 & 30,- kr. \\
\hline Nr. $15 / 16$ & $30,-\mathrm{kr}^{*} *$ \\
\hline Nr. 17 & 35,- kr. \\
\hline Nr. 18 & 45,- kr. \\
\hline Nr. $19 / 20$ & 55,- kr. \\
\hline Nr. 21 & 50,- kr. \\
\hline Nr. 22 & 50,- kr. \\
\hline Nr. $23 / 24$ & 65,- kr. \\
\hline Nr. 25 & 54,- kr. \\
\hline Nr. 26 & 48,- kr. \\
\hline Nr. $27 / 28$ & 55,- kr. \\
\hline
\end{tabular}

Bestilling sker ved indbetaling af ét af disse beløb. Anfør på girotalonen, hvad indbetalingen dækker.

NB. Tidligere abonnementsrakker kan ikke bestilles til gammel abonnementspris.

* De vigtigste artikler er optrykt i antologien STATEN I DET KAPITALISTISKE SAMFUND, KURASJE 1979. 


\section{I lobet af de sidste 11/2 år har vi bl.a. bragt folgende artikler:}

Nr. 23/24, april 1980

Statsintervention og reformismekritik

Reformismen - realitet eller ideologi

Massearbejdslashed som politiseringspotentiale

Den (u)mulige reproduktion

Videnskabskritik som samfundskritik

Åndsarbejde og videnskabskritik

Nr. 25, november 1980

Kritik af realanalysen

Realanalyse i krisen eller krise i realanalysen?

Arbejderklassens situation $0 \mathrm{~g}$ den statslige krisepolitik

Index til Kurasje nr. 1-25, 1970-80

Nr. 26, januar 1981

Realanalyse og den materialistiske historieopfattelse

Historiske forbemarkninger til rekonstruktionen af en hegemonial marxisme

Kommunismen som det formidlende nye

Kritik af Marx' tingsliggorelsesteori

Nr. 27/28, april 1981

Radikalisering i krisen

Tilpasning eller opror

Hvem sagde krise

Staten $0 \mathrm{~g}$ de materielle produktionsbetingelser

Om forholdet mellem det »logiske« og det whistoriske« i Marx' kritik af den politiske ckonimi

Nr. 29, oktober 1981

Se selv efter?

\section{Abonner på Kurasje - brug Kurasje}

